\title{
Vasoconstrictor Mechanisms in Chronic Hypoxia-Induced Pulmonary Hypertension: Role of Oxidant Signaling
}

\author{
Simin Yan, Thomas C. Resta and Nikki L. Jernigan * \\ Vascular Physiology Group, Department of Cell Biology and Physiology, \\ University of New Mexico Health Sciences Center, Albuquerque, NM 87131, USA; syan@salud.unm.edu (S.Y.); \\ tresta@salud.unm.edu (T.C.R.) \\ * Correspondence: njernigan@salud.unm.edu
}

Received: 5 September 2020; Accepted: 6 October 2020; Published: 15 October 2020

\begin{abstract}
Elevated resistance of pulmonary circulation after chronic hypoxia exposure leads to pulmonary hypertension. Contributing to this pathological process is enhanced pulmonary vasoconstriction through both calcium-dependent and calcium sensitization mechanisms. Reactive oxygen species (ROS), as a result of increased enzymatic production and/or decreased scavenging, participate in augmentation of pulmonary arterial constriction by potentiating calcium influx as well as activation of myofilament sensitization, therefore mediating the development of pulmonary hypertension. Here, we review the effects of chronic hypoxia on sources of ROS within the pulmonary vasculature including NADPH oxidases, mitochondria, uncoupled endothelial nitric oxide synthase, xanthine oxidase, monoamine oxidases and dysfunctional superoxide dismutases. We also summarize the ROS-induced functional alterations of various $\mathrm{Ca}^{2+}$ and $\mathrm{K}^{+}$channels involved in regulating $\mathrm{Ca}^{2+}$ influx, and of Rho kinase that is responsible for myofilament $\mathrm{Ca}^{2+}$ sensitivity. A variety of antioxidants have been shown to have beneficial therapeutic effects in animal models of pulmonary hypertension, supporting the role of ROS in the development of pulmonary hypertension. A better understanding of the mechanisms by which ROS enhance vasoconstriction will be useful in evaluating the efficacy of antioxidants for the treatment of pulmonary hypertension.
\end{abstract}

Keywords: reactive oxygen species; pulmonary vasoconstriction; calcium influx; calcium sensitization; pulmonary hypertension; chronic hypoxia

\section{Introduction}

The pulmonary circulation is normally a low resistance and low-pressure system with a mean pulmonary arterial pressure (mPAP) less than $20 \mathrm{mmHg}$ [1]. Pulmonary hypertension (PH) is diagnosed by resting mPAP greater than $20 \mathrm{mmHg}$ accompanied by pulmonary vascular resistance $\geq 3$ Wood Units in pre-capillary $\mathrm{PH}$, and classified as either idiopathic (pulmonary arterial hypertension, $\mathrm{PAH}, \mathrm{WHO}$ Group 1 ) or secondary to left heart diseases (WHO Group 2), chronic hypoxic lung diseases (WHO Group 3), thrombosis (WHO Group 4), or of unclear reasons (WHO Group 5) [1].

$\mathrm{PH}$ is typically not diagnosed at early stages until the appearance of heart failure symptoms [2] such as dyspnea, palpitation and lower-extremity edema, which can ultimately lead to morbidity and mortality. This review will address many forms of $\mathrm{PH}$ with a focus on chronic hypoxia $(\mathrm{CH})$-induced $\mathrm{PH}$, which occurs in patients with chronic obstructive pulmonary diseases (COPD), restrictive lung diseases, sleep apnea and in residents at high altitude.

Narrowing of pulmonary arteries (PAs) as a result of both structural (pulmonary arterial remodeling) and functional changes (vasoconstriction) contributes to increased vascular resistance that is pivotal 
to the pathogenesis of $\mathrm{PH}$. Although pulmonary arterial wall thickening is observed in $\mathrm{CH}$-induced $\mathrm{PH}[3-5]$, augmented vasoconstriction, manifested as both resting pulmonary arterial tone and reactivity to endogenous vasoconstrictors, plays an indispensable role in this disease [6-10]. Enhanced pulmonary arterial vasoconstriction results from pulmonary arterial smooth muscle cell (PASMC) hyperreactivity mediated by cytosolic $\mathrm{Ca}^{2+}$-dependent and $\mathrm{Ca}^{2+}$-sensitization mechanisms [11-22] as well as pulmonary arterial endothelial cell (PAEC) dysfunction via unbalanced production of vasoconstrictors over vasodilators [23]. Increased reactive oxygen species (ROS) have been widely reported to mediate augmented pulmonary arterial constriction [3,12,18-20,22,24-28] (Figure 1), and antioxidation strategies provide therapeutic efficacy in animal models of $\mathrm{PH}[3,29-37]$.

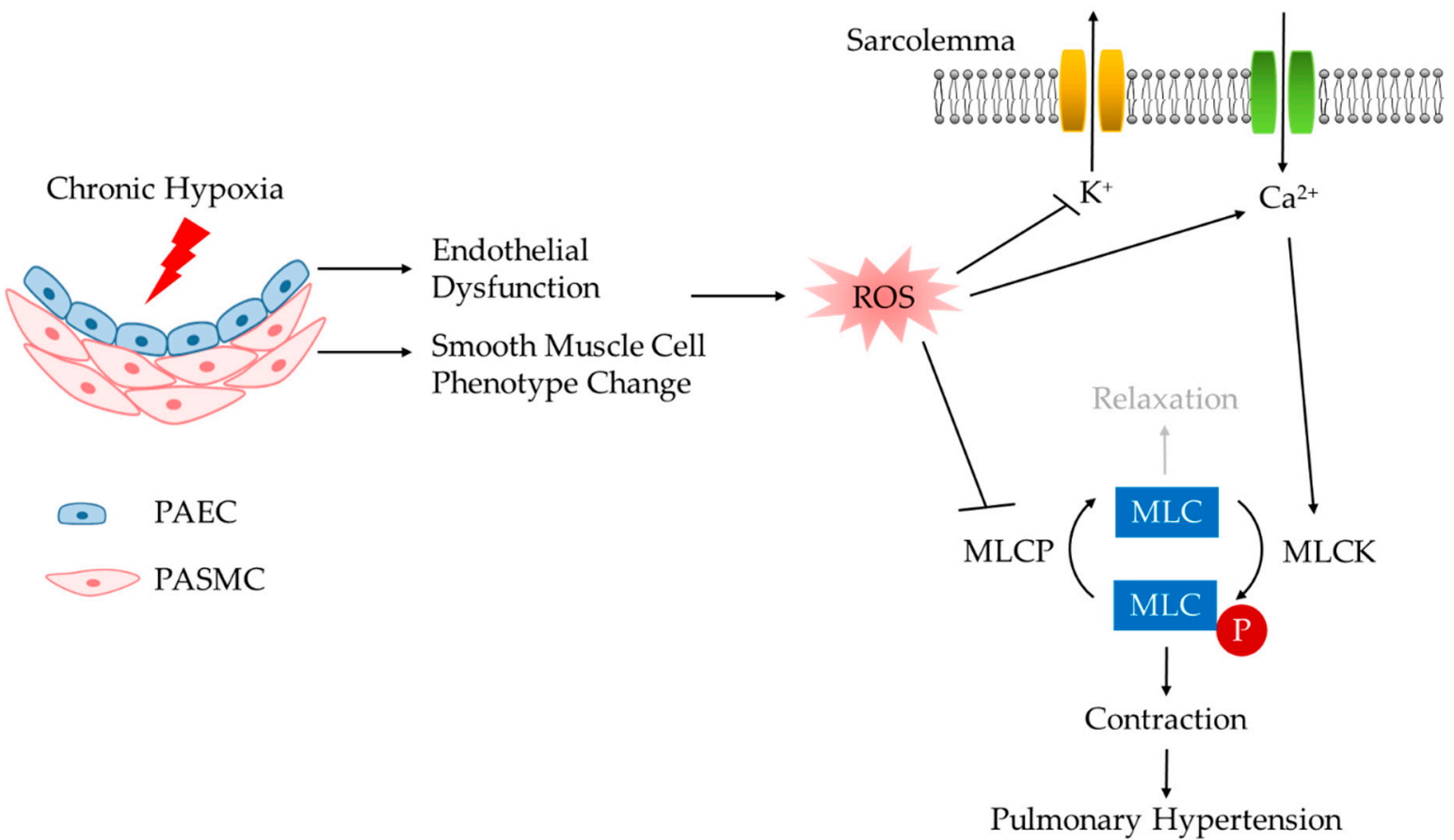

Figure 1. Enhanced vasoconstriction resulting from chronic hypoxia-induced functional alterations of endothelial and smooth muscle cells contributes to pulmonary hypertension. PAEC, pulmonary arterial endothelial cell; PASMC, pulmonary arterial smooth muscle cell; ROS, reactive oxygen species; MLCK, myosin light chain kinase; MLCP, myosin light chain phosphatase; MLC, myosin light chain.

\section{ROS in the Pathogenesis of PH}

ROS are a group of oxygen-derived molecules with one or more unpaired electrons in their outer orbit. Superoxide anions $\left(\mathrm{O}_{2} \cdot{ }^{-}\right)$are formed when molecular oxygen $\left(\mathrm{O}_{2}\right)$ receives an electron, and is derived from various sources including NADPH oxidases (NOXs), mitochondria, endothelial nitric oxide synthase (eNOS), xanthine oxidase (XO) and monoamine oxidases (MAOs). The other two forms of ROS, peroxynitrite ion $\left(\mathrm{ONOO}^{-}\right)$and hydrogen peroxide $\left(\mathrm{H}_{2} \mathrm{O}_{2}\right)$, are derivatives of $\mathrm{O}_{2} \cdot{ }^{-}$. Specifically, the combination of $\mathrm{O}_{2} \cdot{ }^{-}$and nitric oxide (NO) produces $\mathrm{ONOO}^{-}$and partial reduction of $\mathrm{O}_{2}{ }^{-}$by superoxide dismutase (SOD) generates $\mathrm{H}_{2} \mathrm{O}_{2}$. There are three known SOD isoforms found in mammals including SOD1 (Cu-Zn SOD), located in the cytoplasm and intermembrane space of mitochondria, SOD2 (Mn SOD), located in the mitochondrial matrix, and SOD3 (Cu-Zn SOD), located extracellularly [38]. $\mathrm{H}_{2} \mathrm{O}_{2}$ is fully reduced to water $\left(\mathrm{H}_{2} \mathrm{O}\right)$ by catalase or glutathione peroxidase (Figure 2). 


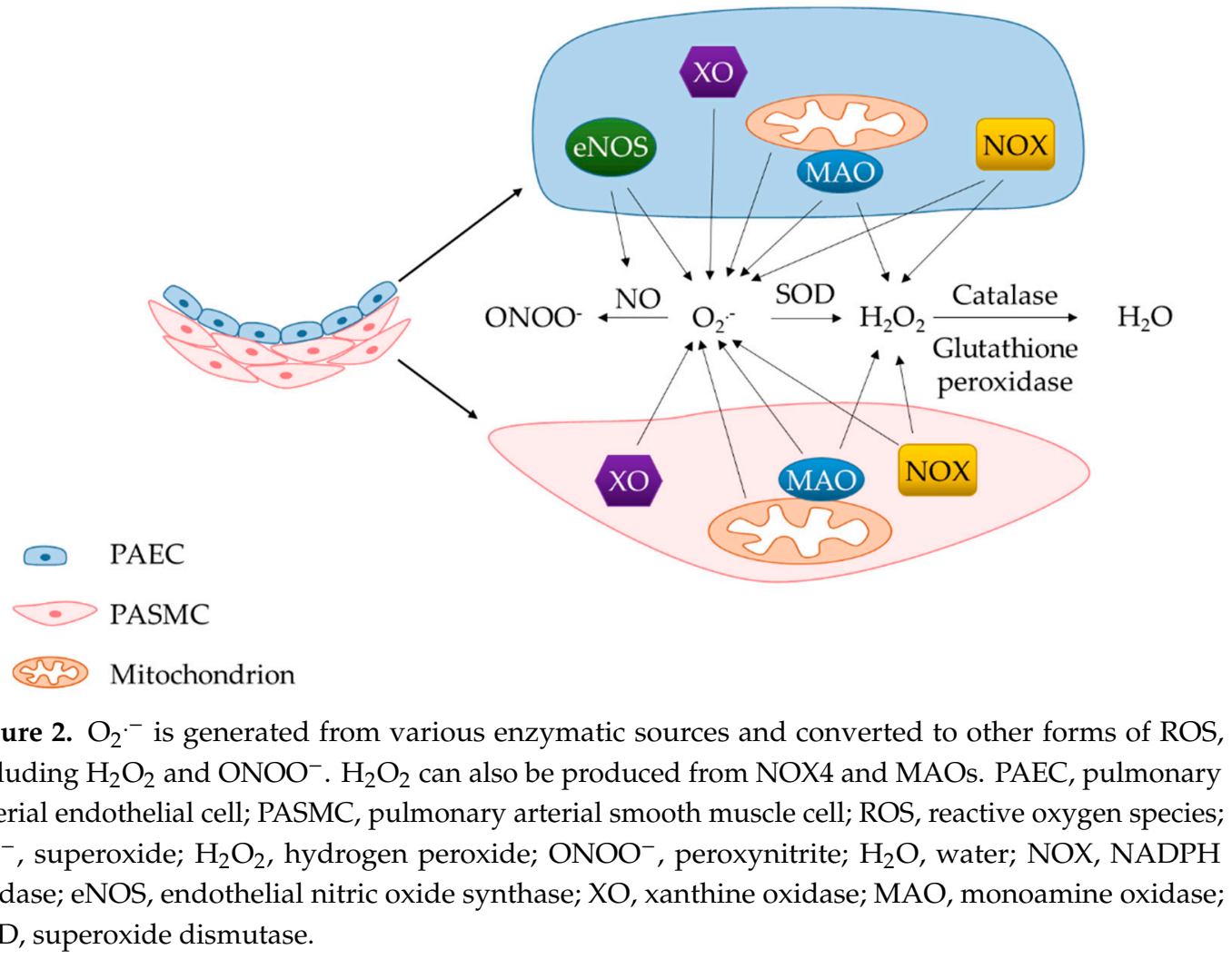

Under normal conditions, ROS are essential signaling molecules that are tightly regulated to maintain physiological homeostasis, regulate cellular proliferation, and host defense. Within the vasculature, ROS contribute to basal endothelial cell proliferation/migration [39,40], as well as smooth muscle cell differentiation [41]. ROS can also participate in vasomotor responses such as autoregulation [42], endothelium-dependent vasodilation [43,44], flow-mediated vasodilation [45], hypoxic pulmonary vasoconstriction (HPV) [46,47] and hyperoxia-induced vasoconstriction [48-50]. At physiological concentrations, $\mathrm{H}_{2} \mathrm{O}_{2}$ elicits vasodilation in the pulmonary circulation [51-54] and diminishes $\mathrm{HPV}$ in $\mathrm{CH}$ animals [55]. In addition, oxidation of protein kinase $\mathrm{G}$ I $\alpha$ by oxidants $\left(\mathrm{H}_{2} \mathrm{O}_{2}\right.$, glutathione disulfide, and protein-bound persulfides) following $\mathrm{CH}$ counteracts enhanced PA constriction and is protective during $\mathrm{PH}$ development [56], suggesting that under certain conditions ROS can play a protective role. However, $\mathrm{H}_{2} \mathrm{O}_{2}$ has also been reported to be detrimental in $\mathrm{PH}[29,57,58]$. This contradictory effect of $\mathrm{H}_{2} \mathrm{O}_{2}$ in the pulmonary circulation may be due to a variety of conditions, including the concentration of $\mathrm{H}_{2} \mathrm{O}_{2}$, experimental setup, cell type affected and intracellular signaling mechanism involved. Other forms of ROS involved in the pathogenesis of $\mathrm{PH}$ include $\mathrm{O}_{2} \cdot{ }^{-}[3,12,26,29,59,60]$ and $\mathrm{ONOO}^{-}$[61-63]. Although physiological levels of ROS are indispensable in maintaining vascular homeostasis, excess production leads to disease development [64-67] as detailed in the following sections.

$\mathrm{O}_{2}{ }^{-}$is considered to be highly reactive and can mediate cell signaling either directly or through its derivatives, $\mathrm{H}_{2} \mathrm{O}_{2}$ and $\mathrm{ONOO}^{-}$. These ROS participate in signaling transduction by making posttranslational modifications to ion channels, protein kinases and other signaling molecules [68-70]. Such protein modifications include oxidation of tyrosine, tryptophan, histidine, lysine, methionine and cysteine residues [70]. In this review, we discuss the ROS-induced functional alterations to relevant $\mathrm{Ca}^{2+}$ channels, $\mathrm{K}^{+}$channels and other proteins that contribute to enhanced PA constriction in $\mathrm{PH}$. Despite the observed effects of ROS, current knowledge about the exact chemical reactions, amino acid residues affected, and resulting protein structural changes is still limited. The most widely documented modifications in this setting are cysteine oxidative modifications (Figure 3), including S-glutathionylation (e.g., L-type voltage-gated $\mathrm{Ca}^{2+}$ channels [71,72] and STIM1 [73]), disulfide formation (e.g., ASIC1 [74], 
voltage-gated $\mathrm{K}^{+}$channels [75,76] and RhoA [77]), and sulfenic acid formation (e.g., voltage-gated $\mathrm{K}^{+}$ channel [78]).

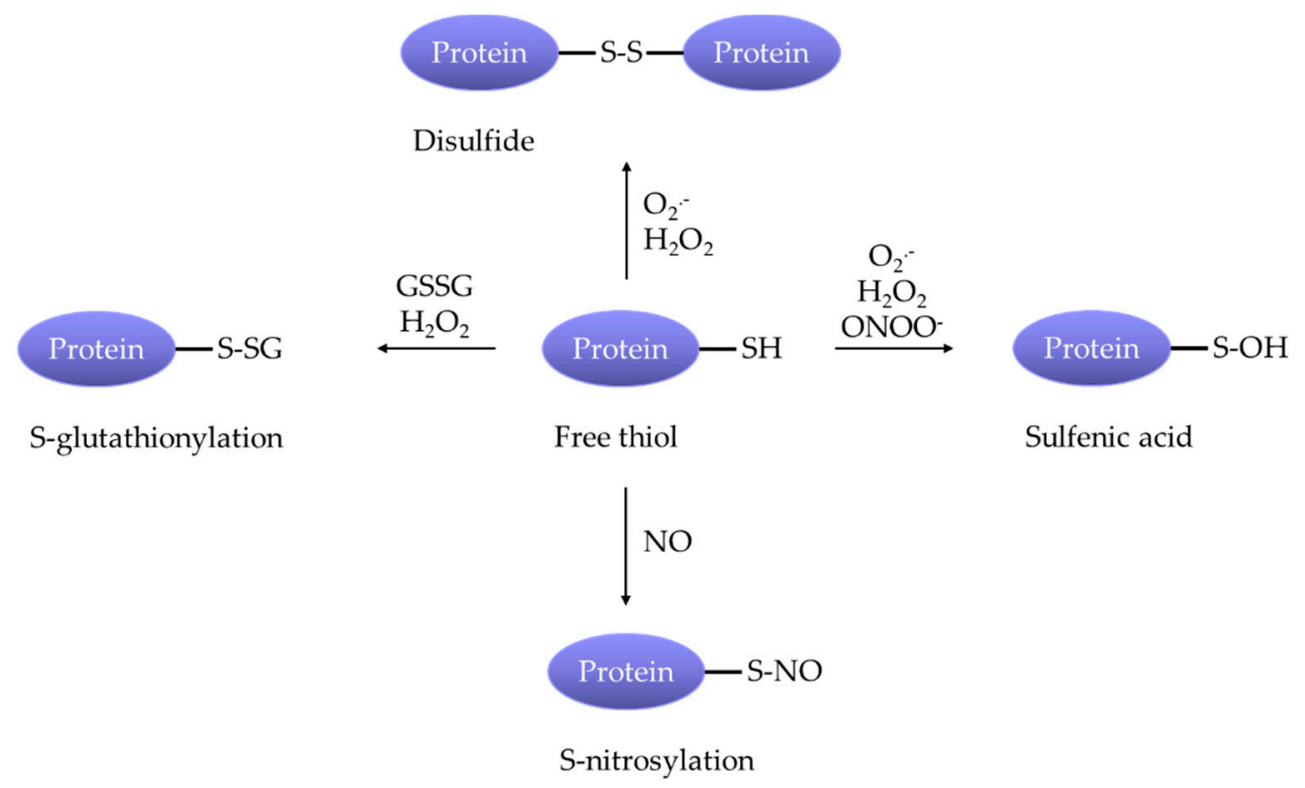

Figure 3. ROS facilitate pulmonary arterial constriction in pulmonary hypertension by make various posttranslational modifications at cysteine residues of ion channels and molecules.

\subsection{Increased ROS Production in $P H$}

\subsubsection{NADPH Oxidase Family}

The NOX family consists of a group of enzymes that transfer an electron from NADPH to $\mathrm{O}_{2}$, therefore generating $\mathrm{O}_{2} \cdot{ }^{-}$. NOX-derived ROS were first identified as effectors from phagocytes responsible for host defense [79] and later as mediators in various cellular processes. All enzymes within this family contain one of the seven ROS-generating catalytic homologs including NOX1, NOX2, NOX3, NOX4, NOX5, DUOX1 and DUOX2 [79]. Some of them are reported to be expressed within the pulmonary vasculature, as summarized in Table 1. NOX enzymes are comprised of several subunits, both catalytic and regulatory, that are located both intracellularly and extracellularly. This fact makes it possible for enzyme function to be regulated by its associated regulatory subunits as well as various intra- and extracellular signals $[79,80]$.

Table 1. Expression of NOX isoforms in the pulmonary vasculature.

\begin{tabular}{|c|c|c|c|}
\hline NOX Isoform & Expression in PAEC & Expression in PASMC & ROS Generated \\
\hline NOX2 & Human $[81,82,89,90]$, rat $[84]$, mouse $[89,91]$ & Rat [92] & $\mathrm{O}_{2}--[81,89]$ \\
\hline NOX4 & Human $[81,82,94]$, rat $[84]$, mouse [95] & Human $[90,96]$, rat $[86,92]$, mouse $[90]$ & $\mathrm{O}_{2}{ }^{-}[82,97], \mathrm{H}_{2} \mathrm{O}_{2}[82,95,96]$ \\
\hline
\end{tabular}

NOX1 expression is greater in PAs from PAH patients compared to vessels from control patients [83] and contributes to the proliferation of both PAEC [83] and PASMC [86]. In monocrotaline-induced PAH model, NOX1 expression is increased in PASMCs [87]. Moreover, N-acetylcysteine, which suppresses NOX1 expression, is protective against monocrotaline-induced PAH [86]. In addition to PAH, NOX1 has also been shown to participate in $\mathrm{PH}$ elicited by $\mathrm{CH}$ as evidence by effects of genetic global deletion of NOX1 to abolish the $\mathrm{CH}$-induced elevation in right ventricular systolic pressure (RVSP), right ventricle (RV) hypertrophy and PA remodeling in mice [98].

NOX2 expression is upregulated in response to prolonged [29] in vitro hypoxia. Using PAs isolated from wild type and gp91phox deficient mice, Liu et al. [24] discovered that NOX2-derived 
$\mathrm{O}_{2} \cdot{ }^{-}$production in PAs is higher after $\mathrm{CH}$ exposure. Additionally, augmented PA contraction to ET-1 following $\mathrm{CH}$ is NOX2 dependent [24]. Evidence from our group also supports that NOX2-derived ROS contribute to enhanced PA constriction following $\mathrm{CH}[18,22]$.

NOX4 is unique among the NOX family since it is intrinsically active once expressed [99-101]. Although biochemical evidence suggests $\mathrm{H}_{2} \mathrm{O}_{2}$ is the major product of NOX4 [99-101], NOX4-dependent generation of both $\mathrm{O}_{2} \cdot{ }^{-}[82,97]$ and $\mathrm{H}_{2} \mathrm{O}_{2}[82,95,96]$ has been observed in the pulmonary vasculature. NOX4 expression in PAs from COPD patients [102] and CH mice [90] is higher than those from controls. NOX4 promotes proliferation of human PASMCs [90] and correlates with the severity of PA remodeling in COPD patients [102], suggesting a pathological role for NOX4 in $\mathrm{CH}$-induced $\mathrm{PH}$. In comparison to wild-type (WT) mice, Hood et al. [98] demonstrated that RVSP is diminished in NOX4 knockout (KO) mice following $\mathrm{CH}\left(10 \% \mathrm{O}_{2}\right.$ for 15 days). However, these NOX4 $\mathrm{KO}$ mice develop a similar degree of RV hypertrophy and PA remodeling as WT mice. In contrast, Veith et al. [103] reported that both global and inducible NOX4 KO mice exhibit similar elevations in RVSP after CH exposure ( $10 \% \mathrm{O}_{2}$ for 21 days) as WT mice. The reason for these discrepant results is not clear, but may be due to differences in the duration of $\mathrm{CH}$ exposure or animal sex, as Hood et al. [98] studied only female mice. Since NOX4 does not account for monocrotaline-induced PAH [87], it appears that involvement of NOX4 in PH may differ depending on the model employed. In addition to evidence against a detrimental role of NOX4 in $\mathrm{PH}$, a recent study demonstrates that increased disulfide protein kinase $\mathrm{G} \mathrm{I} \alpha$ during $\mathrm{CH}$, likely caused by NOX4-derived $\mathrm{H}_{2} \mathrm{O}_{2}$, opposes the pathogenesis of $\mathrm{PH}$ [56]. This possible beneficial effect of NOX4 in $\mathrm{CH}$-induced $\mathrm{PH}$ is consistent with previous investigations showing the protective role of NOX4 in cardiovascular diseases. For example, endothelial NOX4 alleviates both angiotensin II-induced hypertension [104] and hemodynamic overload-induced cardiac remodeling [105].

\subsubsection{Mitochondria}

Mitochondria are double-membrane organelles responsible for efficient energy generation from the electron transport chain (ETC), which is located in the inner membrane. Electrons from NADH and $\mathrm{FADH}_{2}$, extracted by complex I (NADH dehydrogenase) and complex II (succinate dehydrogenase) respectively, flow through the ETC and are received by $\mathrm{O}_{2}$ at complex IV to generate $\mathrm{H}_{2} \mathrm{O}$. A small amount of ROS are inevitably produced during this process because of "electron leak" [106]. A mitochondrial antioxidation system scavenges mitochondria-derived ROS (mitoROS) so that normal cell function can be maintained. This antioxidant system is comprised of SOD2 in the matrix and SOD1 in the intermembrane space, both of which convert $\mathrm{O}_{2} \cdot{ }^{-}$into $\mathrm{H}_{2} \mathrm{O}_{2}[107,108] . \mathrm{H}_{2} \mathrm{O}_{2}$ in the mitochondrial matrix is further detoxified by glutathione peroxidase 1 (GPX1) $[109,110]$ or catalase $[29,110,111]$. It is mainly reported that mitoROS are generated from complex I and III with $\mathrm{O}_{2}{ }^{-}$as the primary product [112]. The role of mitoROS in $\mathrm{CH}$-induced $\mathrm{PH}$ has been studied by several groups. Human PAECs exposed to prolonged hypoxia $(72 \mathrm{~h}$ ) have greater mitoROS levels versus normoxic controls [29]. MitoROS within PAEC participate in $\mathrm{Ca}^{2+}$ homeostasis as supported by data that higher intracellular $\mathrm{Ca}^{2+}$ in PAECs from SU5416/hypoxia-induced PAH rats versus those from normoxic animals is acutely diminished by the mitochondria-targeted antioxidant MitoQ [113]. A recent study from our laboratory similarly employed the mitochondrial antioxidants MitoQ and MitoTEMPO to demonstrate that mitoROS production is greater in PASMCs from $\mathrm{CH}$ neonatal rats compared to normotensive animals and contributes to enhanced PA vasoconstriction following $\mathrm{CH}$ [114]. Since MitoQ suppresses mitochondrial $\mathrm{O}_{2}{ }^{-}$generation, it suggests the involvement of mitochondria-derived $\mathrm{O}_{2}{ }^{-}$in the pathology of $\mathrm{PH}$. Using genetically modified mice, other groups reported that mitochondrial $\mathrm{H}_{2} \mathrm{O}_{2}$ is also pathogenic in the development of $\mathrm{PH}$ elicited by $\mathrm{CH}$. Evidence from Adesina et al. [29] show that indices of $\mathrm{CH}$-induced $\mathrm{PH}$, including RVSP, RV hypertrophy and PA remodeling, are attenuated by mitochondrial catalase overexpression, which breaks down mitochondrial $\mathrm{H}_{2} \mathrm{O}_{2}$, but are exacerbated by SOD2 overexpression, which increases mitochondrial $\mathrm{H}_{2} \mathrm{O}_{2}$. 


\subsubsection{Endothelial Nitric Oxide Synthase}

$\mathrm{NO}$, an important vasodilator in the pulmonary vasculature [115], is produced by eNOS using L-arginine as substrate, which requires the cofactor tetrahydrobiopterin (BH4) $[116,117]$. eNOS is constitutively expressed in endothelial cells and has 3 domains, a reductase domain in the $C$ terminus, an oxygenase domain in the $\mathrm{N}$ terminus and a linking domain $[118,119]$. Binding of $\mathrm{Ca}^{2+} /$ camodulin to the linking domain activates the enzyme, allowing NADPH oxidation to occur at the reductase domain. Flavin mononucleotide (FMN) and flavin adenine dinucleotide (FAD) of the reductase domain of one monomer pass electrons from NADPH to the heme-containing oxygenase domain of a second monomer via BH4 $[117,119]$, which couples NADPH oxidation to L-arginine oxidation. NO is synthesized from $\mathrm{O}_{2}$ and L-arginine at the oxygenase domain through a multi-step chemical reaction including: (1) the combination of $\mathrm{O}_{2}$ with the heme group of the oxygenase domain to form a ferrous-dioxygen complex; (2) reduction of $\mathrm{O}_{2}$ within the ferrous-dioxygen complex to form $\mathrm{H}_{2} \mathrm{O}$; and (3) oxidation of L-arginine to produce NO and L- citrulline [116-118,120]. Results from Vásquez-Vivar et al. [116] demonstrate that $\mathrm{BH} 4$ stabilizes the ferrous-dioxygen complex to prevent $\mathrm{O}_{2}{ }^{-}{ }^{-}$generation from eNOS. Thus, without adequate availability of $\mathrm{BH} 4$, eNOS produces $\mathrm{O}_{2}{ }^{-}$[121]. $\mathrm{O}_{2}{ }^{--}$, in turn, can oxidize $\mathrm{BH} 4$. $\mathrm{BH} 4$ oxidation is detrimental because it further reduces $\mathrm{BH} 4$ bioavailability and produces dihydrobiopterin (BH2) [122], a process that additionally favors $\mathrm{O}_{2} \cdot{ }^{-}$generation from eNOS [123]. Interestingly, it is also reported that increases in $\mathrm{BH} 2$ alone, without a change of $\mathrm{BH} 4$ levels, are sufficient to induce $\mathrm{O}_{2} \cdot{ }^{-}$generation [121], suggesting the $\mathrm{BH} 4 / \mathrm{BH} 2$ ratio is key to regulation of eNOS function. Therefore, a deleterious cycle is established in which uncoupled eNOS produces $\mathrm{O}_{2} \cdot{ }^{-}$, and $\mathrm{O}_{2} \cdot{ }^{-}$further uncouples eNOS.

$\mathrm{BH} 4-\mathrm{eNOS}$ coupling is important in maintaining physiologically low pulmonary arterial pressure as evident by the effect of BH4 deficient mice to increase endothelial $\mathrm{O}_{2} \cdot{ }^{-}$levels as well as right ventricular systolic pressure compared to wild type mice under normoxia, regardless of changes in eNOS expression [124]. In addition, pathological hypoxic exposure triggers more severe $\mathrm{PH}$ in BH4-deficient mice versus WT mice, which is attenuated by genetic BH4 restoration [124]. The importance of BH4-eNOS coupling in $\mathrm{CH}$-induce $\mathrm{PH}$ is also supported by research findings from Dikalova et al. [31], in which oral BH4 administration attenuates the development of $\mathrm{CH}$-induced $\mathrm{PH}$ in piglets. The therapeutic potential of $\mathrm{BH} 4$ is demonstrated by effects of $\mathrm{BH} 4$ treatment to reverse established $\mathrm{CH}$-induced $\mathrm{PH}$ in rats [34]. Consistent with evidence that supplementation of BH4 [116,123-126] and an increased BH4/oxidized BH4 ratio [31,121,123] enhance eNOS activity, oral $\mathrm{BH} 4$ administration promotes eNOS activity, lowers lung $\mathrm{O}_{2}{ }^{-}$levels, and reverses established $\mathrm{CH}$-induced $\mathrm{PH}$ [34]. Additionally, $\mathrm{BH} 4$ is shown to be beneficial in the treatment of a rat $\mathrm{PAH}$ model [127].

In addition to $\mathrm{BH} 4$ oxidation, $\mathrm{O}_{2}{ }^{-}$can mediate inhibition of eNOS by exogenous $\mathrm{NO}[63,128,129]$, a response that correlates with the clinical observation that sudden withdrawal of inhaled NO therapy worsens PH in children [130] and infants [131] with congenital heart diseases. In primary ovine PAEC cultures, Sheehy et al. [128] discovered that reduced eNOS activity by the NO donor sodium nitroprusside is partially restored by the $\mathrm{O}_{2}{ }^{-}$scavenger Tiron. Since the reduction of eNOS activity by $\mathrm{NO}$ is not related to cell viability, eNOS expression, subcellular localization, or phosphorylation of eNOS [128], the mechanism by which ROS mediate NO-induced eNOS inhibition remains unclear in this cell model. More in-depth mechanisms are revealed by effects of NO inhalation to inhibit eNOS activity in a lamb model $[63,129]$. The involvement of ROS is implicated by the fact that $\mathrm{O}_{2}{ }^{-}$and $\mathrm{ONOO}^{-}$are increased in PAs following $24 \mathrm{~h}$ of $\mathrm{NO}$ inhalation [63]. The subsequent elevated nitration of eNOS by $\mathrm{ONOO}^{-}$[63] is known to reduce enzyme activity [129]. Furthermore, lambs receiving polyethylene glycol-conjugated superoxide dismutase (PEG-SOD) at the same time of NO inhalation do not show rebound $\mathrm{PH}$ after acute $\mathrm{NO}$ withdrawal seen in those treated with vehicle [63]. Taken together, these data suggest exogenous $\mathrm{NO}$ leads to $\mathrm{O}_{2} \cdot{ }^{-}$generation in the pulmonary vasculature, which reacts with $\mathrm{NO}$ to produce $\mathrm{ONOO}^{-}$. The resultant nitration of eNOS suppresses its activity. 


\subsubsection{Xanthine Oxidase}

The final two biochemical reactions of purine catabolism, namely conversions of hypoxanthine to xanthine to uric acid, are catalyzed by xanthine oxidoreductase (XOR). XOR consists of one molybdenum, two different iron-sulfur centers, and one FAD that all function as electron transporters [132-134]. An $\mathrm{NAD}^{+}$-dependent form of $\mathrm{XOR}$, called xanthine dehydrogenase (XDH), is constitutively expressed, which fulfills purine degradation and generates NADH [135]. However, through oxidation of cysteine residues or proteolytic cleavage, XDH can be converted into xanthine oxidase (XO) $[134,136]$. Due to a decrease in $\mathrm{NAD}^{+}$affinity and an increase in $\mathrm{O}_{2}$ affinity at the FAD site, $\mathrm{XO}$ exhibits high xanthine $/ \mathrm{O}_{2}$ reductase activity instead of high xanthine/NAD ${ }^{+}$reductase activity seen in $\mathrm{XDH}$ [132-136]. Therefore, purine catabolism catalyzed by XO produces ROS [132-136]. Experimental data from Kelley et al. [137] show that $\mathrm{XO}$ generates both $\mathrm{H}_{2} \mathrm{O}_{2}$ and $\mathrm{O}_{2}{ }^{-{ }^{-}}$with the former as the main product ( $>70 \%$ of ROS) under both normoxic $\left(21 \% \mathrm{O}_{2}\right)$ and hypoxic conditions. Interestingly, when the $\mathrm{O}_{2}$ concertation is less than $10 \%$, the proportion of $\mathrm{H}_{2} \mathrm{O}_{2}$ produced is inversely related to $\mathrm{O}_{2}$ concentration and can up to $90 \%$ in the presence of $1 \% \mathrm{O}_{2}$ [137], indicating the involvement of $\mathrm{H}_{2} \mathrm{O}_{2}$ in XO-mediated diseases caused by hypoxia.

In the context of $\mathrm{PH}$, enhanced $\mathrm{XO}$ activity upon hypoxic exposure has been confirmed in both in vitro [138] and in vivo [35,36] studies. Experimental inhibition of $\mathrm{XO}$ is protective against $\mathrm{CH}$-induced increases in mPAP [35], RV hypertrophy [35,36] and pulmonary arterial wall thickening [35,36] in animal models. Consistently, compared to placebo treatment, XO inhibitor treatment (allopurinol) alleviates RV hypertrophy in COPD-associated PH patients with severe airflow limitation in a double-blinded randomized controlled clinical trial [139].

\subsubsection{Monoamine Oxidases}

Monoamine oxidases (MAOs) catalyze the oxidative deamination of bioactive amines and are found in brain as well as various human tissues [140]. MAO type A (MAO-A) and MAO type B (MAO-B) are two identified MAO isoforms characterized by different substrate preferences [141]. In particular, MAO-A oxidizes dopamine, norepinephrine and serotonin (5-HT), while MAO-B reacts with dopamine, phenylethylamine, benzylamine and tryptamine [142-146]. Substrate selectivity of MAOs is determined by phenylalanine residue 208 of MAO-A and isoleucine residue 199 of MAO-B [146]. During the oxidative deamination process, FAD, a cofactor of MAOs, delivers electrons from amines to molecular $\mathrm{O}_{2}$ to generate ROS [147], including $\mathrm{O}_{2}{ }^{-}$[148,149] and $\mathrm{H}_{2} \mathrm{O}_{2}$ [150-153]. Therefore, MAOs can act as sources of ROS. One of the downstream targets of MAOs is mitochondria, which is consistent with evidence that MAOs are tethered to the outer membrane of mitochondria [154] via a C terminal transmembrane helix $[155,156]$. Specifically, MAOs mediate mitochondrial dysfunction [157-160] and promote mitoROS production $[158,159]$. Within the pulmonary circulation, MAO-A is expressed in PAs and contributes to $\mathrm{O}_{2}{ }^{--}$generation triggered by 5-HT [148]. Preliminary observations from Sun and colleagues demonstrate that expression of MAO-A is upregulated in PAH patients [161] and that the MAO-A inhibitor clorgyline partially reverses indices of PH in a PAH rat model (SU5416/hypoxia), including RVSP, RV hypertrophy and PA remodeling [161,162]. However, the role of MAOs-derived ROS in vasoconstrictor responses of PAs and their contribution to $\mathrm{CH}$-induced $\mathrm{PH}$ remains unclear.

\subsection{Decreased Antioxidant Capacity in PH}

Augmented ROS signaling can also result from decreased antioxidant capacity. Impaired SOD activity has been reported in a variety of PH models of animals and patients [33,163-168]. Aiming at rescuing the dysfunctional SOD system, SOD mimetics have been demonstrated to alleviate indices of $\mathrm{PH}$ following $\mathrm{CH}[3,32,37]$. As mentioned before, three SOD isoforms are found in mammals [38] and all of them are reported to be important in the pathogenesis of $\mathrm{PH}$. 


\subsubsection{SOD1}

Expression of the predominant cytosolic SOD isoform, SOD1, is lower in PAs from CH piglets [165] and $\mathrm{CH}$ adult rats [28] in comparison to normoxic controls, a response associated with increased $\mathrm{O}_{2}{ }^{-}$ and decreased $\mathrm{H}_{2} \mathrm{O}_{2}$ levels. However, the role of SOD1 in $\mathrm{CH}$-induced $\mathrm{PH}$ is not clear. Interestingly, compared to WT mice, SOD1 KO mice display elevated $\mathrm{O}_{2}{ }^{-}$levels in PAs, exhibit enhanced vasoreactivity to ET-1, as well as greater RV hypertrophy, PA remodeling and greater RVSP under normoxia [166]. Collectively, these results indicate that loss of SOD1 in response to $\mathrm{CH}$ may contribute to the pathogenesis of $\mathrm{PH}$.

\subsubsection{SOD2}

SOD2 is localized to the mitochondrial matrix [38]. SOD2 expression is reported to be downregulated in $\mathrm{PH}$ including in a $\mathrm{CH}$ mouse model [169], persistent $\mathrm{PH}$ lamb model [170], PAH patients [168] and a fawn-hooded rat model of PAH [164]. Loss of SOD2 in PASMCs during CH exposure may promote PA remodeling since SOD2 suppresses proliferation and promotes apoptosis of hypoxic cultures of human PASMCs [171]. It is also been shown that loss of SOD2 in PAECs is involved in elevated PA constriction in PH. In a PH neonatal lamb model established by ligation of the fetal patent ductus arteriosus during late gestation, SOD2 restoration in PAECs by adenovirus vectors reduces mitochondrial $\mathrm{O}_{2}{ }^{-}$levels and restores eNOS expression [170], suggesting an improvement of PA dilation. Moreover, SOD2 transduction in PA rings from $\mathrm{PH}$ animals ameliorates their relaxation in response to the NO-dependent vasodilator, ATP, compared to control transduction [170]. Since the greater $\mathrm{H}_{2} \mathrm{O}_{2}$ production following restoration of SOD2 expression is thought to be responsible for the observed upregulation of eNOS [170], these findings suggest that mitochondria-derived $\mathrm{H}_{2} \mathrm{O}_{2}$ is protective. However, Adesina et al. [29] found that $\mathrm{CH}$-induced RV hypertrophy, PA muscularization and increases in RSVP are exacerbated in a transgenic mouse model overexpressing SOD2 in comparison to WT mice. In this study, increased mitochondrial $\mathrm{H}_{2} \mathrm{O}_{2}$ is shown to be detrimental rather than protective.

\subsubsection{SOD3}

SOD3 locates extracellularly by binding to extracellular matrix components such as heparan sulfate proteoglycan, collagen and fibulin-5 [38]. Since introduction of extracellular ROS by administration of $X O$ [172] and knockdown of SOD3 by siRNA [173] in cultured human PASMCs triggers pro-proliferative and anti-apoptotic phenotypic changes, it suggests extracellular $\mathrm{O}_{2}{ }^{-}{ }^{-}$, as well as SOD3 are likely important in the pathogenesis of $\mathrm{PH}$. Considering that expression [28] and activity $[28,173]$ of SOD3 in PAs are reduced by $\mathrm{CH}$ exposure, genetically modified animals with SOD3 deletion have been used to study its role in $\mathrm{CH}$-induced $\mathrm{PH}$ development. Compared to control animals, mice with smooth muscle-specific SOD3 KO [174] or global SOD3 KO [175] exhibit greater RVSP, RV hypertrophy and pulmonary arterial wall thickening following $\mathrm{CH}$. In line with this, SOD3 overexpression protects against $\mathrm{CH}$-induced $\mathrm{PH}$ [30]. In addition to favoring PASMC proliferation, extracellular ROS also participate in $\mathrm{CH}$-induced extracellular matrix remodeling as SMC SOD3 deletion augments $\mathrm{CH}$-induced collagen deposition in PAs [174]. While dysfunctional SOD3 has been reported to be associated with PA remodeling, the role of SOD3 in enhanced PA vasoconstriction following $\mathrm{CH}$ is undetermined except for evidence that SOD3 helps to maintain normal eNOS function. Nozik-Grayck and colleagues [174] found that eNOS activation and GTP cyclohydrolase-1 (GTPCH-1, a key enzyme for BH4 synthesis) levels are diminished in lungs from smooth muscle-specific SOD3 KO mice exposed to $\mathrm{CH}$, while eNOS expression is unaltered. These results are consistent with the notion that the loss of SOD3 contributes to development of PH. 


\section{ROS Modulation of Augmented PA Constriction}

The effect of $\mathrm{CH}$ to augment $\mathrm{PA}$ vasoconstrictor reactivity has been convincingly demonstrated [6-10]. Smooth muscle contraction is triggered by an increase in intracellular $\mathrm{Ca}^{2+}$ levels $\left(\left[\mathrm{Ca}^{2+}\right]_{i}\right)$ via either $\mathrm{Ca}^{2+}$ influx or $\mathrm{Ca}^{2+}$ release from the sarcoplasmic reticulum (SR). $\mathrm{Ca}^{2+}$ binds to calmodulin and actives myosin light chain kinase (MLCK). When the regulatory light chain of myosin is phosphorylated by MLCK, cross-bridge cycling occurs and results in smooth muscle contraction $\left(\mathrm{Ca}^{2+}\right.$-dependent mechanism). Contraction ends when phosphorylated myosin light chain is dephosphorylated by myosin light chain phosphatase (MLCP). Therefore, factors that inhibit MLCP activity can maintain smooth muscle contraction and contribute to prolonged vasoconstriction independent of changes in $\left[\mathrm{Ca}^{2+}\right]_{\mathrm{i}}\left(\mathrm{Ca}^{2+}\right.$ sensitization mechanism). Both increases in $\left[\mathrm{Ca}^{2+}\right]_{\mathrm{i}}$ in PASMCs $[11,17,176-180]$ and $\mathrm{Ca}^{2+}$ sensitization $[12,18,20-22,180-182]$ are known to mediate enhanced PA vasoconstriction in response to $\mathrm{CH}$.

\subsection{ROS Modulation of $\mathrm{Ca}^{2+}$-Dependent Vasoconstriction}

\subsection{1. $\mathrm{Ca}^{2+}$ Influx}

$\mathrm{Ca}^{2+}$ influx is thought to contribute to the increase in $\left[\mathrm{Ca}^{2+}\right]_{\mathrm{i}}$ in PASMCs after $\mathrm{CH}$ exposure, which can involve either voltage-gated calcium channels (VGCC) or non-selective cation channels (i.e., conduct both $\mathrm{Ca}^{2+}$ and $\mathrm{Na}^{+}$) including receptor-operated channels (ROC), store-operated channels (SOC), and mechanosensitive channels (MSCs) (Figure 4).

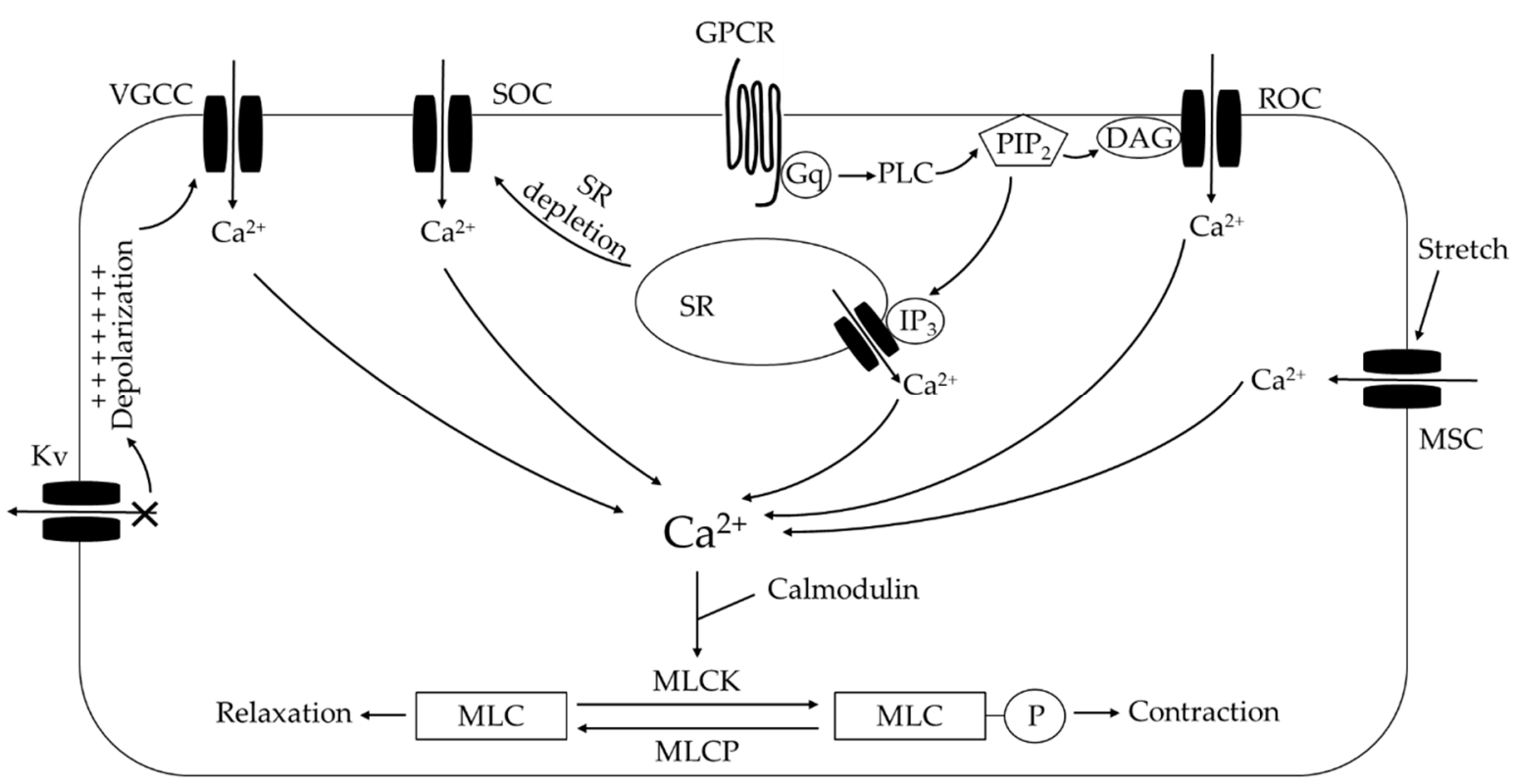

Figure 4. Summary of $\mathrm{Ca}^{2+}$-dependent influx and release mechanisms in pulmonary arterial smooth muscle cells following chronic hypoxia. See text for details. $\mathrm{K}_{\mathrm{V}}$, voltage-gated $\mathrm{K}^{+}$channel; VGCC, voltage-gated $\mathrm{Ca}^{2+}$ channel; SOC, store-operated channel; ROC, receptor-operated channel; MSC, mechanosensitive channel; GPCR, G protein-coupled receptor; PLC, phospholipase C; $\mathrm{PIP}_{2}$, phosphatidylinositol 4,5-bisphosphate; DAG, diacylglycerol; $\mathrm{IP}_{3}$, inositol triphosphate; $\mathrm{SR}$, sarcoplasmic reticulum; MLCK, myosin light chain kinase; MLCP, myosin light chain phosphatase; MLC, myosin light chain.

VGCC are gated by plasma membrane potential. Based on their sensitivity to depolarization, they are classified as high voltage-activated channels (L-, P/Q-, R-, N-type) and low voltage-activated (T-type) channels [183]. L-type and T-type VGCC are found in the pulmonary circulation [184]. Since membrane potential is a product of uneven distribution of $\mathrm{Na}^{+}, \mathrm{K}^{+}$and $\mathrm{Cl}^{-}$across the plasma membrane, 
the opening of non-selective cation channels (increased $\mathrm{Na}^{+}$influx) and closing of $\mathrm{K}^{+}$channels (reduced $\mathrm{K}^{+}$efflux) lead to membrane depolarization and VGCC activation [185]. Plasma membrane depolarization is observed in PASMCs from CH animals [186,187] and PAH patients [188].

ROC s are controlled by diacylglycerol (DAG) generated from Gq protein-coupled receptor pathway activation [189]. SOCs are activated when intracellular SR Ca ${ }^{2+}$ stores are depleted [190]. When $\mathrm{Ca}^{2+}$ depletion in the SR is sensed by stromal interaction molecule (STIM) [190], STIM moves towards the plasma membrane and activates store-operated $\mathrm{Ca}^{2+}$ entry (SOCE) via Orai [191], acid-sensing ion channels (ASICs) [17,192] and transient receptor potential (TRP) channels [193].

$\mathrm{Ca}^{2+}$ channel expression and/or activity have been shown to be increased by $\mathrm{CH}$ and coupled to enhanced vasoconstriction (Table 2). $\mathrm{Ca}^{2+}$ signaling contributes to PA constriction [189]. However, it is worthwhile to note that some research findings may be animal model-specific. Previous data from our laboratory demonstrate the existence of differences in $\mathrm{Ca}^{2+}$ handling after $\mathrm{CH}$ exposure in two commonly used strains of rats [194]. In particular, $\mathrm{CH}$ induces an elevation in resting smooth muscle $\left[\mathrm{Ca}^{2+}\right]_{\mathrm{i}}$ in Wistar rats but not in Sprague-Dawley (SD) rats [194]. Additionally, SOCE is attenuated by $\mathrm{CH}$ in SD rat while augmented in Wistar rats [194].

Table 2. $\mathrm{Ca}^{2+}$ influx in $\mathrm{CH}$-induced $\mathrm{PH}$.

\begin{tabular}{|c|c|c|}
\hline Channel/Molecule & Alteration by $\mathrm{CH}$ & Functions \\
\hline \multirow[t]{7}{*}{ L-type VGCC } & \multirow[t]{7}{*}{$\begin{array}{l}\text { Increased current density [195], } \\
\text { channel upregulation (Cav1.2) [196] }\end{array}$} & $\begin{array}{l}\text { Positive: } \\
\text { Mediate CH-induced enhanced pulmonary vascular tone [195] and PA } \\
\text { vasoconstriction to } \mathrm{KCl}[195,196] \text { and to L-type VGCC activator [195] }\end{array}$ \\
\hline & & Negative: \\
\hline & & 1. Without effects on basal $\left[\mathrm{Ca}^{2+}\right]_{\mathrm{i}}$ in PASMCs or basal PA tension [180] \\
\hline & & $\begin{array}{l}\text { 2. Responsible for } 30-40 \% \text { of basal }\left[\mathrm{Ca}^{2+}\right]_{\mathrm{i}} \text { in cultured PASMCs but not } \\
\text { affect basal PA tone [178] }\end{array}$ \\
\hline & & $\begin{array}{l}\text { 3. Do not contribute to increase PA wall basal }\left[\mathrm{Ca}^{2+}\right]_{i} \text { or elevated PA } \\
\text { constriction to UTP following } \mathrm{CH}[17]\end{array}$ \\
\hline & & 4. Do not contribute to $\mathrm{CH}$-induced augmentation of PA myogenic tone [21] \\
\hline & & $\begin{array}{l}\text { 5. CH-induced PH is not acutely alleviated by L-type VGCC inhibition in } \\
\text { SD rats [197] or COPD patients }[198,199]\end{array}$ \\
\hline \multirow[t]{3}{*}{ T-type VGCC } & \multirow[t]{3}{*}{ Channel upregulation (Cav3.2) [196] } & $\begin{array}{l}\text { Positive: } \\
\text { Mediate } \mathrm{CH} \text {-induced augmented PA constriction to } \mathrm{K}^{+} \text {and U-46619 [196] } \\
\text { Negative: }\end{array}$ \\
\hline & & 1. Do not contribute to increase PA wall basal $\left[\mathrm{Ca}^{2+}\right]_{\mathrm{i}}$ following $\mathrm{CH}[17]$ \\
\hline & & 2. Do not contribute to $\mathrm{CH}$-induced augmentation of PA myogenic tone [21] \\
\hline \multirow[t]{2}{*}{ TRPC1 } & \multirow[t]{2}{*}{ Channel upregulation $[177,178,200]$} & $\begin{array}{c}\text { CH-induced PH [201,202]; SOCE in PASMC [178,200]; CH-induced } \\
\text { augmented basal tone and vasoconstriction to 5-HT [202] }\end{array}$ \\
\hline & & CH-induced PH [202,203]; ROCE in PASMC [178]; augmented SOCE in \\
\hline \multirow[t]{2}{*}{ TRPC6 } & \multirow[t]{2}{*}{ Channel upregulation $[177,178,203]$} & $\begin{array}{l}\text { PASMCs following CH [203]; basal tone under normoxia [202]; CH-induced } \\
\text { augmented vasoconstriction to 5-HT [202] }\end{array}$ \\
\hline & & 1. CH-induced PH development $[204,206]$ \\
\hline \multirow{3}{*}{ TRPV4 } & Channel upregulation in & 2. CH-induced enhanced myogenic tone [204] and augmented \\
\hline & PASMCs $[204,205]$, increased channel & vasoconstriction to serotonin [206] and TRPV4 agonist [205] but not to \\
\hline & activities in PASMCs $[204,205]$ & $\begin{array}{c}\text { U46619 [204], PE [206] or ET-1 [206] in endothelium-disrupted PAs } \\
\text { 3. } \mathrm{Ca}^{2+} \text {-induced } \mathrm{Ca}^{2+} \text { release in PASMCs [205] }\end{array}$ \\
\hline ASIC1 & Unaltered expression [207] & $\begin{array}{l}\text { Contribute to augmented SOCE and SOCE-induced vasoconstriction in PAs } \\
\text { following } \mathrm{CH} \text { [17]; } \mathrm{CH} \text {-induced } \mathrm{PH}[207]\end{array}$ \\
\hline Orai1 & Upregulation $[14,200,203,208]$ & $\mathrm{CH}$-induced increases in basal $\mathrm{Ca}^{2+}[14]$ and SOCE $[14,200]$ in PASMCs \\
\hline Orai2 & Upregulation $[14,203,208]$ & $\mathrm{CH}$-induced increases in basal $\mathrm{Ca}^{2+}$ and SOCE in PASMCs [14] \\
\hline Orai3 & Unaltered expression [14] & $\mathrm{CH}$-induced increases in basal $\mathrm{Ca}^{2+}$ and SOCE in PASMCs [14] \\
\hline STIM1 & $\begin{array}{l}\text { Upregulation }[200,208] \text {, } \\
\text { unaltered expression [14] }\end{array}$ & $\mathrm{CH}$-induced increases in basal $\mathrm{Ca}^{2+}[14]$ and SOCE $[14,200]$ in PASMCs \\
\hline STIM2 & Upregulation $[203,208]$ & Enhanced SOCE in PASMCs from PH patients [209] \\
\hline MSC & Increased channel activities [176] & CH-induced augmentation of PA myogenic tone $[19,21,176]$ \\
\hline
\end{tabular}

\section{Voltage-Gated Calcium Channels}

As summarized in Table 2, both positive and negative findings are documented for the role of VGCC in the pathogenesis of $\mathrm{CH}$-induced $\mathrm{PH}$. This discrepancy may be due to differences in animal species/strains and hypoxic protocols employed. Even though the role of VGCC in $\mathrm{CH}$-induced $\mathrm{PH}$ is controversial, redox regulation of VGCC is possible. L-type VGCC can be inhibited by NO but stimulated by $\mathrm{ONOO}^{-}$[210], a product from $\mathrm{NO}$ and $\mathrm{O}_{2} \cdot{ }^{-}$. S-nitrosothiols are $\mathrm{NO}$-donors that can cause either L-type VGCC inhibition [211] or activation [210]. Application of $\mathrm{H}_{2} \mathrm{O}_{2}$ [212-214] and oxidized glutathione [71,72] leads to $\mathrm{Ca}^{2+}$ influx through L-type VGCC [212-214]. Further study showed that of 
the Cav1.2 subunit of L-type VGCC is glutathionylated by $\mathrm{H}_{2} \mathrm{O}_{2}$ and oxidized glutathione (GSSG), which increases channel open probability and inward $\mathrm{Ca}^{2+}$ currents [71,72] (Figure 5). The well-known vasoconstrictor ET-1 can also stimulate L-type VGCC-mediated $\mathrm{Ca}^{2+}$ increases in PASMCs from $\mathrm{CH}$ Wistar rats $[180,215]$. Interestingly, this response is plasma membrane depolarization independent [180] but PKC and Rho kinase-dependent [215]. Redox modulation in this process is possible as both PKC [216] and Rho kinase [25] can be activated by oxidation. This possibility is further supported by the fact that ET-1 increases ROS production in PASMCs $[22,217,218]$. Even though this hypothesis is not tested in pulmonary circulation, stimulation of L-type VGCC by ET-1 in isolated cardiac myocytes is demonstrated to be $\mathrm{O}_{2}{ }^{-}{ }^{-}$-mediated [219].

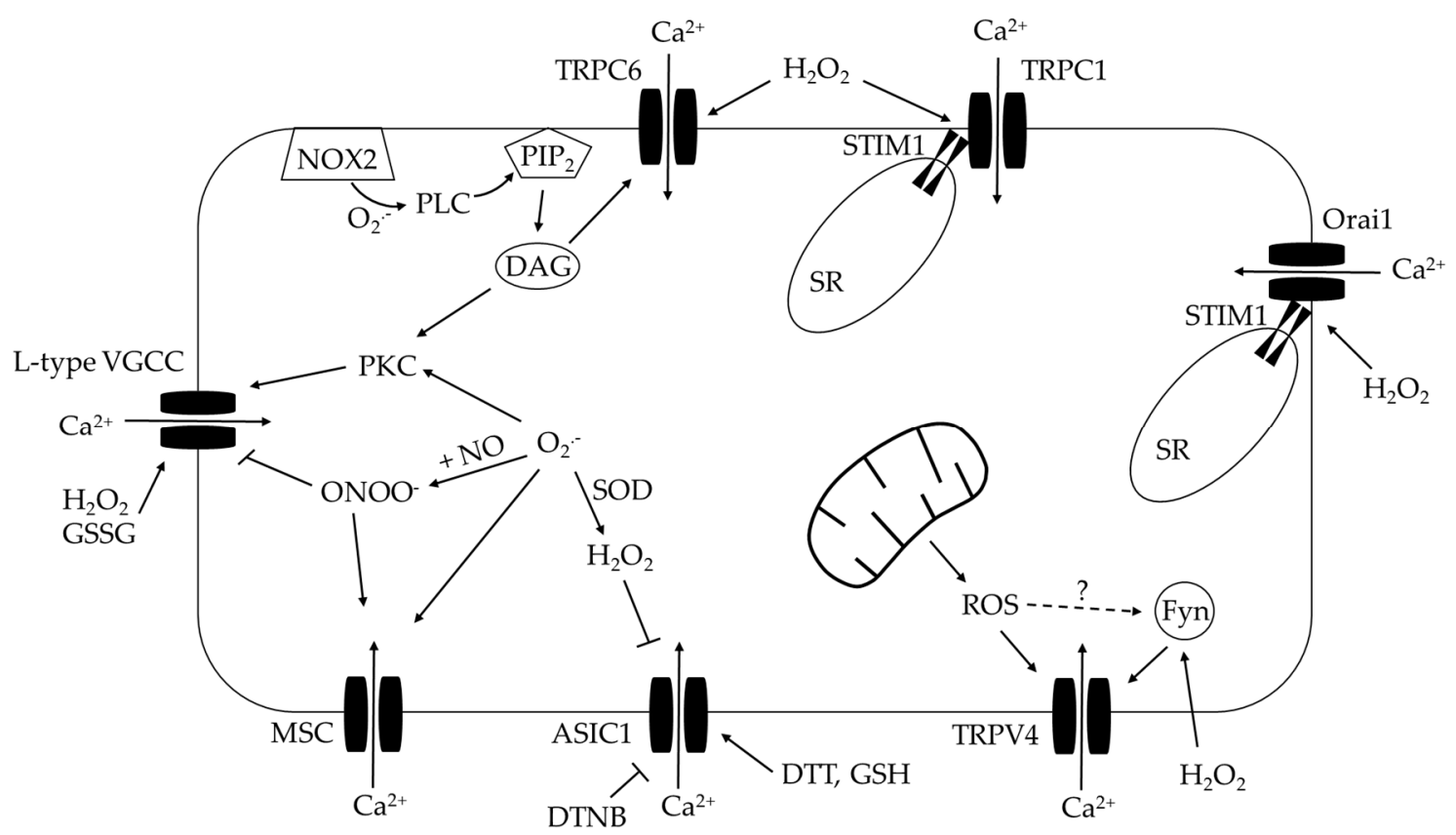

Figure 5. ROS modulation of $\mathrm{Ca}^{2+}$ influx. See text for details. L-type VGCC, L-type voltage-gated $\mathrm{Ca}^{2+}$ channel; TRPC, canonical transient receptor potential channel; TRPV4, transient receptor potential vanilloid 4; ASIC 1, acid sensing ion channel 1; MSC, mechanosensitive channel; NOX2, NADPH oxidase 2; PLC, phospholipase C; $\mathrm{PIP}_{2}$, phosphatidylinositol 4,5-bisphosphate; DAG, diacylglycerol; PKC, protein kinase C; SR, sarcoplasmic reticulum; STIM1, stromal interaction molecule 1 ; ROS, reactive oxygen species; $\mathrm{O}_{2}{ }^{-}$, superoxide; $\mathrm{H}_{2} \mathrm{O}_{2}$, hydrogen peroxide; $\mathrm{ONOO}^{-}$, peroxynitrite; SOD, superoxide dismutase; NO, nitric oxide; Fyn, Fyn kinase; GSSG, oxidized glutathione; GSH, reduced glutathione; DTT, dithiothreitol; DTNB, 5,5'-Dithiobis(2-nitrobenzoic acid).

Transient Receptor Potential Canonical 1 and 6 (TRPC 1 and 6) Channels

TRPC1 and TRPC6 contribute to increased $\left[\mathrm{Ca}^{2+}\right]_{i}$ in PASMCs as well as vasoconstriction following $\mathrm{CH}$ via involvement of SOCE and ROCE as indicated in Table 2. Their activities can be modulated by ROS. TRPC1 is mainly involved in SOCE in PASMC $[178,200]$. Administration of $\mathrm{H}_{2} \mathrm{O}_{2}$ increases STIM1/TRPC1 interactions and SOCE in cultured rat PASMCs [200]. TRPC6 is gated by diacylglycerol (DAG) [220-223]. The production of DAG can be facilitated by ROS. It is documented that NOX2-derived $\mathrm{O}_{2} \cdot{ }^{-}$during ischemia-reperfusion and exogenous $\mathrm{H}_{2} \mathrm{O}_{2}$ phosphorylate and activate phospholipase C (PLC) [222] that generates DAG from cleavage of membrane $\mathrm{PIP}_{2}$. More direct evidence for ROS modulation of TRPC6 is that $\mathrm{H}_{2} \mathrm{O}_{2}$ triggers TRPC6-dependent $\mathrm{Ca}^{2+}$ influx in aortic vascular smooth muscle cells, as well as contraction in endothelium-denuded aorta [224] (Figure 5). 
Transient Receptor Potential Vanilloid 4 (TRPV4) Channels

TRPV4, a member of the TRP channel superfamily, is a $\mathrm{Ca}^{2+}$ permeable non-selective cation channel. TRPV4 is expressed in all three layers of PAs, namely intimal (PAECs) [225-227], medial (PASMCs) [204,205] and adventitial (fibroblasts) layers [228]. Whereas TRPV4 expression in adventitial fibroblasts is upregulated by $\mathrm{CH}$ and contributes to excessive adventitial remodeling during the pathogenesis of PH [228], PASMC TRPV4 channels contribute to enhanced pulmonary vasoconstrictor reactivity following CH [204-206] (Table 2 for details).

In contrast, $\mathrm{Ca}^{2+}$ influx conducted by endothelial TRPV4 is coupled to vasodilation. For example, $\mathrm{Ca}^{2+}$ sparklets via endothelial TRPV4 activate eNOS to cause PA vasodilation [225-227]. Moreover, the PA vasodilator effect of a TRPV4 agonist is absent when NOS is inhibited [226,227,229], supporting the possibility that eNOS is downstream of TRPV4 in PAECs. Another possible mechanism underlying TRPV4-mediated PA dilation is through small/intermediate conductance $\mathrm{Ca}^{2+}$-activated $\mathrm{K}^{+}$ channels $\left(\mathrm{SK}_{\mathrm{Ca}} / \mathrm{IK}_{\mathrm{Ca}}\right)$-dependent endothelium-derived hyperpolarizing factor (EDHF) responses [226]. Intravenous injection of the TRPV4 agonist GSK101790A lowers pulmonary arterial pressure in normal rats [229], although its therapeutic potential in $\mathrm{PH}$ has not been documented.

Interestingly, TRPV4 activity in PAECs is enhanced by ROS. Extracellular $\mathrm{H}_{2} \mathrm{O}_{2}$ increases Ca ${ }^{2+}$ influx via TRPV4 in PAECs from mice and humans [230]. Mechanistically, this response requires TRPV4 phosphorylation by Fyn of the Src family kinases [230]. This process is facilitated by the scaffolding molecule CD36 that brings Fyn and TRPV4 together for efficient phosphorylation [231]. The possible phosphorylation site of TRPV4 that mediates its activation by $\mathrm{H}_{2} \mathrm{O}_{2}$ is serine 824 residue as demonstrated in human coronary artery endothelial cells channels [232]. Moreover, increased basal Ca ${ }^{2+}$ levels in PAECs from PAH rats are normalized by the SOD memetic TEMPOL, by mitochondria-targeted antioxidant MitoQ and by TRPV4 inhibitors [113], suggesting TRPV4 opening is maintained by endogenous ROS from mitochondria. This enhanced TRPV4-mediated $\mathrm{Ca}^{2+}$ entry in PAH animals contributes to proliferation and migration of PAECs [113]. Additionally, MitoQ attenuates TRPV4 agonist (GSK1016790A)-triggered $\mathrm{Ca}^{2+}$ influx observed in PAECs isolated from PAH rats [233] (Figure 5). Whether a similar ROS-induced TRPV4 activation mechanism in PASMCs contributes to elevated $\left[\mathrm{Ca}^{2+}\right]_{\mathrm{i}}$ and vasoconstriction in $\mathrm{PH}$ [204-206], however, remains to be determined.

\section{Acid-Sensing Ion Channel 1 (ASIC1)}

ASICs are members of degenerin/epithelial sodium channels that are activated by extracellular protons. There are at least six known different ASIC subunits (ASIC1a, ASIC1b, ASIC2a, ASIC2b, ASIC3, and ASIC4) that exist in mammals and are encoded by 4 genes (ASIC1-4). Some ASICs, such as ASIC1a homomeric channels and ASIC1a/2b heteromeric channels, also have the ability to conduct $\mathrm{Ca}^{2+}$, therefore directly participating in intracellular $\mathrm{Ca}^{2+}$ homeostasis regulation [234,235]. ASIC subunits are cysteine-rich and modified by the cellular redox status. Reducing agents potentiate ASIC1 activity while oxidizing agents decrease ASIC1 current [74,236-239]. In addition, oxidizing agents like $\mathrm{H}_{2} \mathrm{O}_{2}$ introduce intersubunit disulfide bonds, thereby decreasing the amount of ASIC1a present on the cell surface and reduce acid-evoked currents [74]. Consistent with these studies, we found that $\mathrm{H}_{2} \mathrm{O}_{2}$ inhibited, and PEG-catalase augmented ASIC1-dependent $\mathrm{Ca}^{2+}$ influx in PASMCs [28]. Using a Wistar rat model of hypobaric hypoxia-induced $\mathrm{PH}$, we found that $\mathrm{PASMC} \mathrm{O}_{2}{ }^{-}$- levels are increased and $\mathrm{H}_{2} \mathrm{O}_{2}$ levels are decreased as a result of decreased SOD1 expression and activity [28]. This loss of endogenous $\mathrm{H}_{2} \mathrm{O}_{2}$ following $\mathrm{CH}$ contributes to the augmented ASIC1-dependent $\mathrm{Ca}^{2+}$ influx (Figure 5). The contribution of ASIC1 channels to $\mathrm{CH}$-induced $\mathrm{PH}$ is summarized in Table 2.

\section{Orai/STIM}

STIM locates on SR. Translocation of STIM to plasma membrane upon SR depletion triggers SOCE via Orai channels. Orai/STIM participate in increases in resting cytosolic $\mathrm{Ca}^{2+}$ as well as SOCE following $\mathrm{CH}$ in PASMCs (Table 2). The resulting increase in intracellular $\mathrm{Ca}^{2+}$ levels is believed to couple to 
vasoconstriction but direct evidence for the contribution of Orai/STIM to PA constriction regulation is still absent. Orai/STIM-dependent SOCE can be regulated by ROS since oxidative stress upregulates STIM1 and Orai1 [200], increases STIM1/Orai1 interactions [200], facilitates STIM1 translocation to plasma membrane $[73,240]$ and causes S-glutathionylation of cysteine 56 in STIM1 to trigger sustained $\mathrm{Ca}^{2+}$ entry that is independent of SR depletion [73] (Figure 5).

Mechanosensitive Channels (Aka Stretch-Activated Channels)

MSCs activated by plasma membrane stretch are permeable to $\mathrm{Ca}^{2+}$, therefore increasing $\left[\mathrm{Ca}^{2+}\right]_{i}$. Ducret et al. [176] reported that MSC activity in PASMC is increased by $\mathrm{CH}$ exposure and contributes to myogenic tone of pulmonary arteries from $\mathrm{CH}$ rats whereas the PAs from normoxic animals do not exhibit tone (Table 2). Both $\mathrm{O}_{2} \cdot{ }^{-}$and $\mathrm{ONOO}^{-}$are shown to facilitate stretch-included activation of MSCs [241] (Figure 5).

\subsection{2. $\mathrm{K}^{+}$Efflux}

$\mathrm{K}^{+}$channels selectively conduct outward $\mathrm{K}^{+}$currents that are important in maintaining physiological membrane potential. $\mathrm{K}^{+}$channels can be classified into different categories depending on the gating mechanisms. Within the pulmonary vasculature, four different types of $\mathrm{K}^{+}$channels have been identified, including voltage-gated $\mathrm{K}^{+}$channels $\left(\mathrm{K}_{\mathrm{V}}\right), \mathrm{Ca}^{2+}$-activated $\mathrm{K}^{+}$channels $\left(\mathrm{K}_{\mathrm{Ca}}\right)$, inwardly rectifying ATP-sensitive $\mathrm{K}^{+}$channels $\left(\mathrm{K}_{\mathrm{ATP}}\right)$ and four transmembrane segments-2 pore $\mathrm{K}^{+}$channels $\left(\mathrm{K}_{2 \mathrm{P}}\right)$ [242-244]. Loss of outward $\mathrm{K}^{+}$currents can lead to membrane depolarization. Since plasma membrane depolarization is observed in PASMCs after CH exposure [186,187], a role for suppression of $\mathrm{K}^{+}$channels in this response has been investigated. Membrane depolarization is an important PA constriction stimulus because it activates $\mathrm{Ca}^{2+}$ channels such as VGCCs. Evidence for the involvement of different $\mathrm{K}^{+}$channels will be discussed below.

Loss of $\mathrm{K}_{\mathrm{V}}$ channel function is coupled to enhanced L-type VGCC activity and PA constriction. This is evident by data indicating that general $\mathrm{K}_{\mathrm{V}}$ channel blocker, 4-aminopyridine (4-AP), leads to L-type VGCC dependent increases in cytosolic $\mathrm{Ca}^{2+}$ as well as dose-dependent increases in basal pulmonary arterial tone [245]. Similar findings have been reported using blockers specific for $\mathrm{K}_{V} 7$ (linopirdine and XE991) [246]. Therefore, $\mathrm{K}_{\mathrm{V}}$ channel downregulation and reduced $\mathrm{K}_{\mathrm{V}}$ currents observed in pulmonary vasculature [247-253] following $\mathrm{CH}$ are thought to mediate augmentation of PA constriction. This alteration is pathologically significant as restoration strategies have been shown to be beneficial in limiting $\mathrm{PH}$ [251-253]. $\mathrm{K}_{\mathrm{V}} 1.5$ and $\mathrm{K}_{\mathrm{V}} 2.1$ are of most importance in the context of CH-induced PH [247-253]. Detailed information is summarized in Table 3.

$\mathrm{K}_{\mathrm{V}}$ channels are redox-sensitive primary via the modification of cysteine residues. NOX4 is reported to be colocalized with $\mathrm{K}_{\mathrm{V}} 1.5$ in PASMCs and oxidizes cysteine residues in $\mathrm{K}_{\mathrm{V}} 1.5$ [249]. NOX4 inhibition alleviates the $\mathrm{CH}$-induced reduction in $\mathrm{K}_{\mathrm{V}}$ currents [249]. Studies from Svoboda et al. [78] showed that ROS target the thiol (-SH) group of a cysteine (C581) residue at the $\mathrm{C}$ terminus of $\mathrm{K}_{\mathrm{V}} 1.5$, creating a sulfenic acid modification to $K_{V} 1.5$. Such modification results in a reduction of $K_{V} 1.5$ function by facilitating $K_{V} 1.5$ sequestration [78]. However, ROS modulation of $K_{V} 2.1$ within pulmonary circulation is understudied. In the central nervous system, ROS inhibit $\mathrm{K}_{\mathrm{V}} 2.1$ function by increasing its oligomerization [76,254]. Studies focused on molecular mechanisms of ROS-induced $\mathrm{K}_{\mathrm{V}} 2.1$ oligomerization revealed that $\mathrm{K}_{\mathrm{V}} 2.1$ oligomers are stabilized by disulfide bridges formed by oxidized cysteine residues at position $73[75,76]$ and 710 [76]. 
Table 3. Suppression of $\mathrm{K}_{\mathrm{V}}$ channels following $\mathrm{CH}$ exposure contributes to $\mathrm{PH}$.

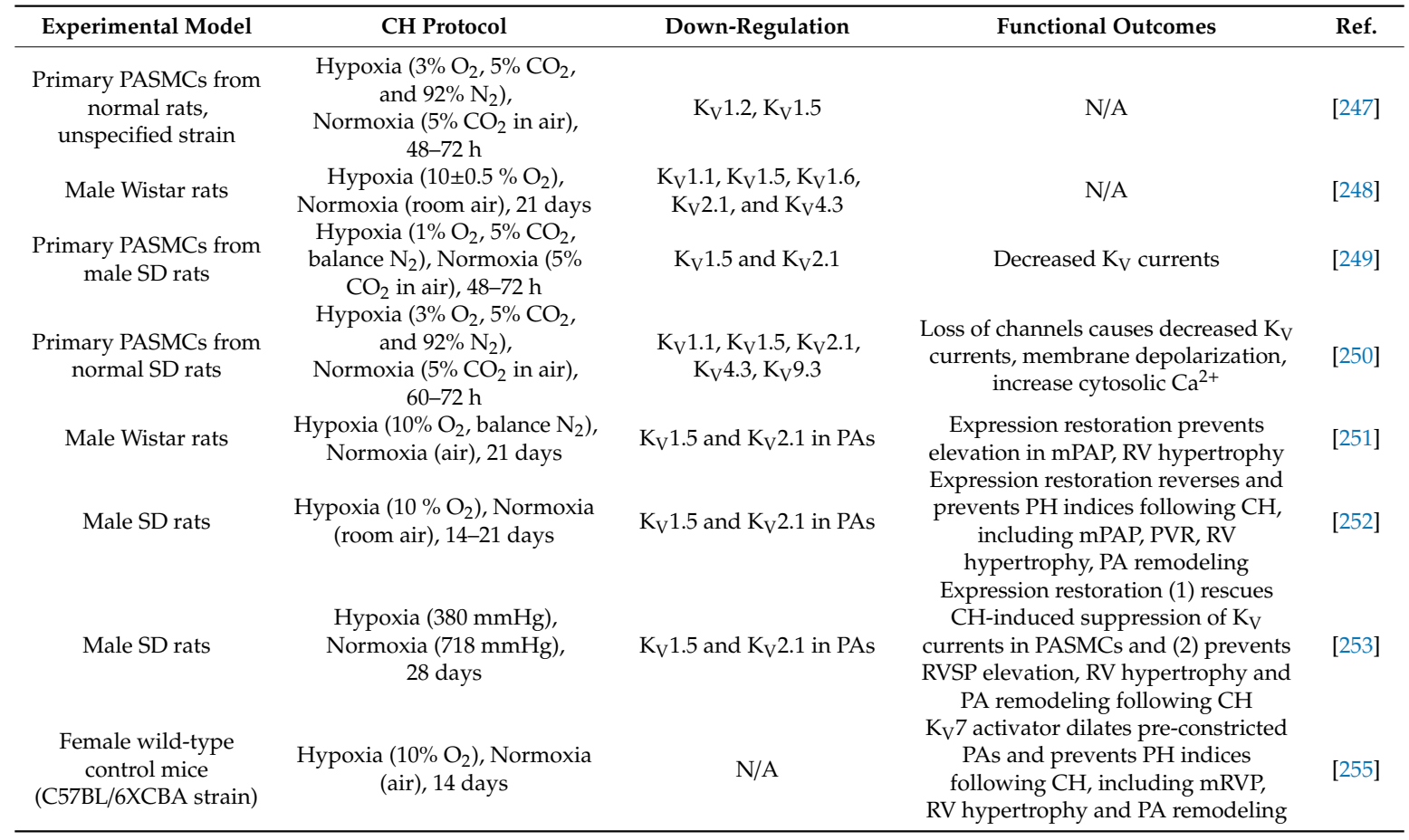

Other $\mathrm{K}^{+}$channels in pulmonary circulation, including $\mathrm{K}_{\mathrm{ATP}}, \mathrm{K}_{\mathrm{Ca}}$ and $\mathrm{K}_{2 \mathrm{P}}$ channels, are less well-studied in PH. Generally, these $\mathrm{K}^{+}$channels exert a vasodilator effect in PAs when involved. The relevant findings are summarized in the following Table 4. Redox regulation of these $\mathrm{K}^{+}$channels is possible but remains unclear in the pulmonary vasculature. As shown in Table 5, both activation and inhibition by ROS were observed in studies from other vascular beds.

Table 4. Other $\mathrm{K}^{+}$channels involved in $\mathrm{CH}$-induced $\mathrm{PH}$ or $\mathrm{PAH}$.

\begin{tabular}{|c|c|c|c|}
\hline Type & Channel & Function & Ref. \\
\hline $\mathrm{K}_{\mathrm{ir}}$ & $\mathrm{K}_{\mathrm{ATP}}$ & $\begin{array}{c}\text { Gain of function protects against } \\
\text { CH-induced PH indices including mPAP, } \\
\text { RV hypertrophy and PA remodeling }\end{array}$ & [256] \\
\hline \multirow[t]{2}{*}{$\mathrm{K}_{\mathrm{Ca}}$} & \multirow[t]{2}{*}{ Large conductance $\mathrm{K}_{\mathrm{Ca}}\left(\mathrm{BK}_{\mathrm{Ca}}\right)$} & $\begin{array}{l}\text { Gain of function protects against } \\
\text { monocrotaline-induced PH, reduces } \\
\text { PDGF-induced PASMC proliferation }\end{array}$ & [257] \\
\hline & & $\begin{array}{l}\text { Loss of function does not affect } \mathrm{PH} \\
\text { development following } \mathrm{CH}\end{array}$ & {$[258]$} \\
\hline $\mathrm{K}_{2 \mathrm{P}}$ & TREK-1 $\left(\mathrm{K}_{2 \mathrm{P}} 2.1\right)$ & $\begin{array}{c}\text { Gain of function leads to PAEC } \\
\text { hyperpolarization and PA relaxation }\end{array}$ & [259] \\
\hline $\mathrm{K}_{2 \mathrm{P}}$ & TWIK-2 (K $\left.{ }_{2 \mathrm{P}} 6.1\right)$ & $\begin{array}{l}\text { Gain of function leads to PAEC } \\
\text { hyperpolarization and PA relaxation }\end{array}$ & [259] \\
\hline $\mathrm{K}_{2 \mathrm{P}}$ & TWIK-2 (KCNK6) & $\begin{array}{l}\text { Loss of function results in increased RVSP, } \\
\text { PA thickening, greater PA vasoconstrictor } \\
\text { to U46619 }\end{array}$ & [260] \\
\hline \multirow{4}{*}{$\mathrm{K}_{2 \mathrm{P}}$} & \multirow{4}{*}{ TASK-1 (KCNK3) } & $\begin{array}{c}\text { Loss of function causes PASMC } \\
\text { depolarization, enhanced }\left[\mathrm{Ca}^{2+}\right]_{\mathrm{i}} \text { and PA } \\
\text { constriction to U46619 }\end{array}$ & [261] \\
\hline & & $\begin{array}{l}\text { Loss of function favors proliferation of } \\
\text { (PAEC, PASMC and fibroblast) and } \\
\text { enhanced basal tone }\end{array}$ & [262] \\
\hline & & $\begin{array}{l}\text { Gain of function protects against } \\
\text { monocrotaline-induced PH }\end{array}$ & {$[262]$} \\
\hline & & $\begin{array}{c}\text { Loss of function is without effects on } \\
\text { CH-induced PH }\end{array}$ & [263] \\
\hline
\end{tabular}


Table 5. ROS modulation of $\mathrm{K}_{\mathrm{ATP}}$ and $\mathrm{K}_{\mathrm{Ca}}$ channels in cardiovascular system.

\begin{tabular}{|c|c|c|c|}
\hline \multirow{2}{*}{ Outcome } & \multicolumn{3}{|c|}{ ROS } \\
\hline & $\mathrm{O}_{2} \cdot-$ & $\mathrm{H}_{2} \mathrm{O}_{2}$ & ONOO $^{-}$ \\
\hline $\begin{array}{c}\mathrm{K}_{\mathrm{ATP}} \\
\text { activation }\end{array}$ & Mesenteric artery SMC [264] & $\begin{array}{c}\text { Mesenteric arteries [265] } \\
\text { Cerebral arteries [266] } \\
\text { Retinal microvessels [267] } \\
\text { Cardiomyocytes [268] }\end{array}$ & $\begin{array}{c}\text { Cerebral arteries [266] } \\
\text { Internal carotid arteries [269] }\end{array}$ \\
\hline $\mathrm{K}_{\text {ATP }}$ inhibition & Cerebral arteries [270] & A10 cell line [271] & N/A \\
\hline $\mathrm{K}_{\mathrm{Ca}}$ activation & Cerebral arteries [266] & $\begin{array}{c}\text { Coronary arteries }[272-274] \\
\text { Cerebral arteries }[266,275]\end{array}$ & Arteriolar SMC [276] \\
\hline $\mathrm{K}_{\mathrm{Ca}}$ inhibition & $\begin{array}{l}\text { Coronary arteries [277] } \\
\text { Cerebral arteries [270] }\end{array}$ & Renal arteries [278] & $\begin{array}{c}\text { Coronary artery SMC [279] } \\
\text { Gracilis arteries [280] }\end{array}$ \\
\hline
\end{tabular}

\subsection{ROS Participate in $\mathrm{Ca}^{2+}$ Sensitization}

\subsubsection{Rho Kinase Mediates Enhanced $\mathrm{Ca}^{2+}$ Sensitization}

Enhanced vasoconstrictor responses in small PAs following $\mathrm{CH}$ can also be mediated by a $\mathrm{Ca}^{2+}$-independent mechanism in which vasoconstriction is independent of changes in intracellular $\mathrm{Ca}^{2+}$ levels. The contractile state of PASMCs results from the balance of MLCK and MLCP activities. $\mathrm{Ca}^{2+}$-independent vasoconstriction happens when phosphorylation of myosin light chain is maintained due to loss of MLCP activity. Phosphorylation of MLCP inhibits its function, which can be achieved by Rho kinase (ROK) either directly or indirectly via phosphorylated myosin light chain phosphatase inhibitor protein CPI-17 [281-283] (Figure 6). ROK is activated by GTP-bound RhoA [281,284]. Inhibition of ROK exerts a vasodilator effect on pulmonary vasculature $[181,282,285]$ and therapeutic strategies targeting $\mathrm{RhoA} / \mathrm{ROK}$ signaling is protective against $\mathrm{CH}$-induced $\mathrm{PH}$ development in various animal models [282,286-289]. These observations suggest that RhoA/ROK represents a crucial mechanism underlying the pathogenesis of $\mathrm{PH}$ following $\mathrm{CH}$. Pathophysiologically, ROK mediates the development of myogenic tone [19,21,181], along with enhanced vasoconstrictor reactivity to ET-1 [12,182] and membrane depolarizing stimuli following $\mathrm{CH}$ [18-20]. ROK can promote actin polymerization in PASMCs $[19,288,290]$. Our laboratory has demonstrated that such cytoskeletal remodeling actions of RhoA/ROK account for augmented PA constriction following $\mathrm{CH}$ [19]. ROK also facilities vasoconstriction by reducing eNOS expression as the inhibition of ROK increases eNOS expression in lungs of $\mathrm{CH}$ mice [282].

\subsubsection{ROS Regulation of RhoA/ROK Signaling}

Generally, the RhoA/ROK pathway can be activated by hypoxia [290], by plasma membrane depolarization [20,291-294] and by signals from G protein-coupled receptors, receptor tyrosine kinases, cytokine receptors and integrins [281,284]. Activated ROK phosphorylates the myosin phosphatase target subunit 1 (MYPT1) of MLCP at multiple threonine and serine residues [295], therefore inhibiting MLCP. Direct evidence for redox regulation of ROK activity is that the $\mathrm{O}_{2}{ }^{-}$donor, LY83583, increases ROK-dependent MYPT1 phosphorylation in PAs [27]. Additionally, ROS can mediate ROK activation in PAs in response to stimuli such as U46619 [25] and CH [12,20]. ROS are important in linking various pathogenic stimuli, such as receptor activation and membrane depolarization, to ROK-dependent $\mathrm{Ca}^{2+}$ sensitization in PASMCs in the setting of $\mathrm{CH}$, therefore contributing to enhanced vasoconstriction [9]. 


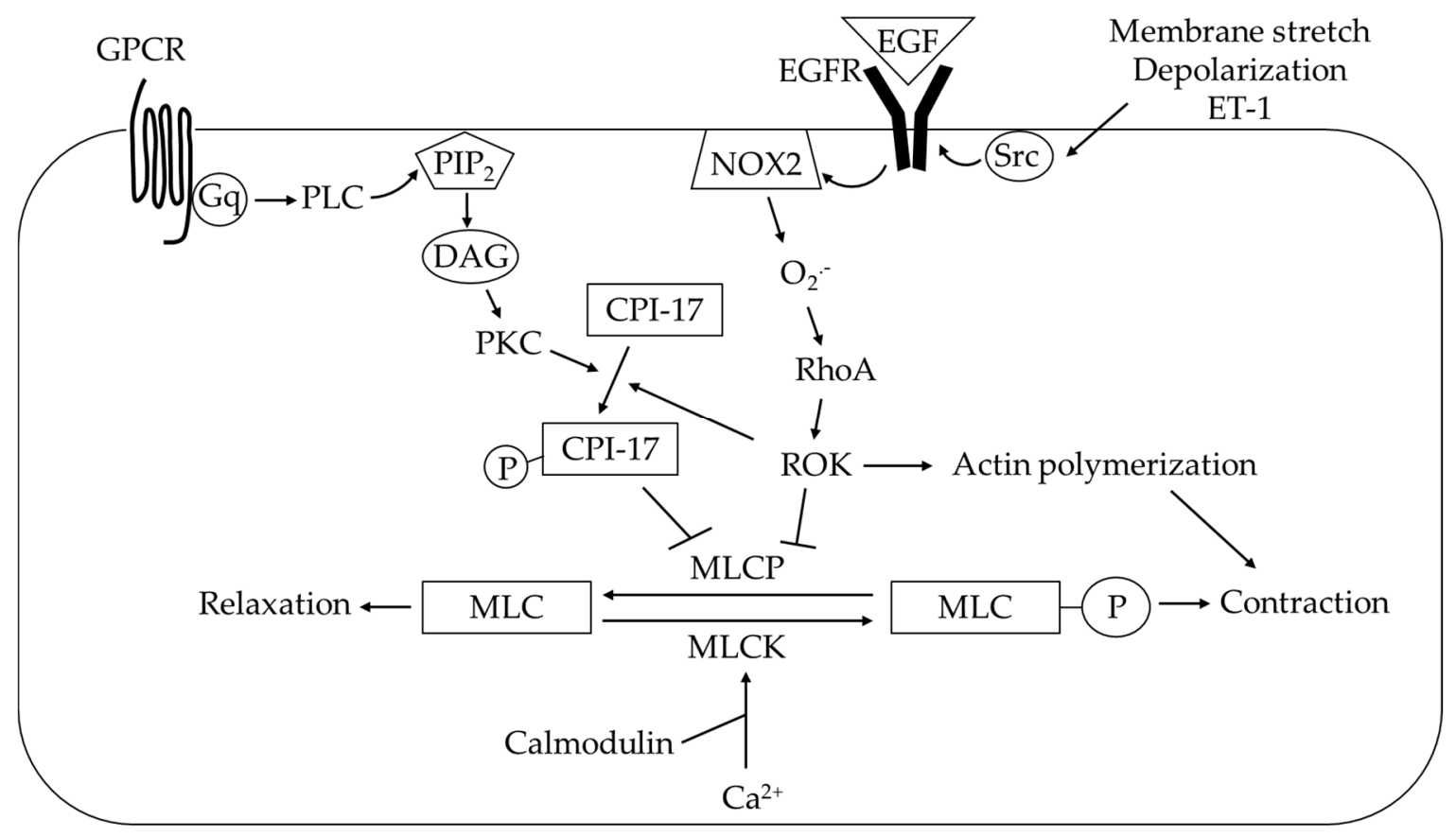

Figure 6. Summary of $\mathrm{Ca}^{2+}$ sensitization in pulmonary arterial smooth muscle cells. Myofilament $\mathrm{Ca}^{2+}$ sensitization is facilitated by ROS following $\mathrm{CH}$. In particular, membrane stretch and endothelin 1 (ET-1) activate Src kinase-epidermal growth factor receptor (EGFR)-NADPH oxidase 2 (NOX2) signaling axis that contributes to $\mathrm{CH}$-induced augmentation of $\mathrm{Ca}^{2+}$-independent pulmonary vasoconstriction and pulmonary hypertension. See text for details. GPCR, G protein-coupled receptor; PLC, phospholipase C; $\mathrm{PIP}_{2}$, phosphatidylinositol 4,5-bisphosphate; DAG, diacylglycerol; PKC, protein kinase $\mathrm{C}_{;} \mathrm{O}_{2}{ }^{--}$, superoxide; ROK, Rho kinase; MLCP, myosin light chain phosphatase; MLCK, myosin light chain kinase; MLC, myosin light chain.

The molecular mechanism by which ROS modulate RhoA/ROK signaling is not fully understood. Upregulation of RhoA under hypoxia appears to be downstream of ROS production [296]. RhoA is a member of Rho GTPase family whose function is regulated by guanine nucleotide-binding state [297]. RhoA is activated when binds to GTP with facilitation from guanine nucleotide exchange factors (GEFs) and deactivated by hydrolysis of GTP [297]. ROS have been shown to activate RhoA by targeting its redox-sensitive GXXXXGK(S/T)C motif, which determines guanine nucleotide dissociation $[77,298]$. Within this motif, cysteine residues 16 and 20 are critical for ROS modulation of RhoA activity [77,299].

Previous work from our laboratory has focused on delineating the contribution of ROS-dependent myofilament $\mathrm{Ca}^{2+}$ sensitization to vasoreactivity following $\mathrm{CH}[12,18-22]$. PAs from $\mathrm{CH}$ rats have greater tone compared to vessels from control animals without a difference in $\left[\mathrm{Ca}^{2+}\right]_{\mathrm{i}}$ in PASMCs $[19,21]$, suggesting the importance of the $\mathrm{Ca}^{2+}$ sensitization mechanism in maintaining elevated basal contractile state of PAs following $\mathrm{CH}$. $\mathrm{CH}$ exposure also augments vasoconstriction to agonists independent of changes in $\mathrm{Ca}^{2+}$ because ET-1 [12] and membrane depolarization (KCl) [20] trigger greater constriction in $\mathrm{Ca}^{2+}$-permeabilized $\mathrm{PAs}$ from $\mathrm{CH}$ rats versus normoxic controls. Such differences are abolished by ROS scavengers alone [12,20], ROK inhibition alone [12,20] or combination of ROS scavenger and ROK [20]. Considering RhoA activation upon ET-1 [12] and $\mathrm{KCl}$ [20] stimulation in PAs requires ROS, it suggests ROS signal through ROK to facilitate $\mathrm{CH}$-induced augmentation of myofilament $\mathrm{Ca}^{2+}$ sensitization. Furthermore, elevated $\mathrm{KCl}$-induced vasoconstriction in $\mathrm{Ca}^{2+}$-clamped PAs from $\mathrm{CH}$ rats is normalized by NOX2 inhibition [18], indicating NOX2 as the enzymatic source of ROS involved in $\mathrm{Ca}^{2+}$ sensitization regulation. Upstream of NOX2 is epidermal growth factor receptor (EGFR) activation as EGFR is activated by $\mathrm{KCl}$ and contributes to $\mathrm{KCl}$-induced ROS generation from NOX2 [18]. In summary, an EGFR-NOX2-ROK-mediated $\mathrm{Ca}^{2+}$ sensitization mechanism mediates 
$\mathrm{CH}$-induced augmentation of PA vasoconstriction (Figure 6). This signaling is pathologically important because it participates in the development of $\mathrm{PH}$ following $\mathrm{CH}$ [22].

\section{Conclusion/Perspective}

This review summarizes our understanding of ROS in enhanced PA constriction in the disease of $\mathrm{PH}$, with an emphasis on $\mathrm{CH}$-associated $\mathrm{PH}$. Pathological ROS signaling following $\mathrm{CH}$ is the outcome of increased production from various enzymatic sources, as well as dysfunctional scavenging systems. ROS participate in PA vasomotor tone regulation following $\mathrm{CH}$ by modulating $\mathrm{Ca}^{2+}$ influx, $\mathrm{K}^{+}$efflux and myofilament $\mathrm{Ca}^{2+}$ sensitization. Although ROS have convincingly reported to have an effect on these processes, little is known about the precise ROS-induced modifications to the relevant ion channels and signaling molecules. Limited studies indicate that ROS cause protein phosphorylation at serine residues and target cysteine residues to introduce modifications such as S-glutathionylation, disulfide formation and sulfenic acid formation. However, there are some potential pitfalls associated with such studies. First, the majority of current knowledge about ROS regulation of ion channels is gathered from experiments applying exogenous/extracellular oxidizing reagents, which fail to fully reflect the actions of intracellular ROS seen in PH. Second, there is a lack of pulmonary circulation-specific evidence regarding redox modifications. Third, it remains unclear how these identified ROS-induced modifications alter functions of the affected ion channels and signal transducers. Future studies are therefore needed to address these limitations. Furthermore, the upstream regulatory mechanisms that regulate enzymatic sources of ROS in PH are not fully understood. Such knowledge will be valuable in designing therapies specific to the disease while preserving the physiological functions of ROS.

Considering the importance of ROS in mediating increases in pulmonary vascular resistance (PVR), a number of groups have attempted to develop novel therapeutic strategies for $\mathrm{PH} / \mathrm{PAH}$ by preventing ROS production or scavenging ROS. Pre-clinical studies in $\mathrm{PH} / \mathrm{PAH}$ animal models have shown promising results $[3,29-37,300,301]$. It is likely that oxidative signaling is also involved in human $\mathrm{PH} / \mathrm{PAH}$ as oxidative stress is increased in chronic high-altitude residents [302] and in PH patients [303]. Moreover, in PAH patients, oxidative stress markers correlate with an adverse prognosis [304], and reducing oxidative stress by epoprostenol [305] or by recombinant human angiotensin converting enzyme type 2 (rhACE2) [306] is associated with decreases in PVR in small scale clinical trials. Aside from PVR, preserving or improving right heart function is a crucial goal for disease management [307] because cor pulmonale occurring during $\mathrm{PH}$ is fatal. Unfortunately, antioxidant therapy has shown little success in cardioprotection to date. Oral administration of antioxidant coenzyme $\mathrm{Q}(\mathrm{CoQ})$ improves left and right heart functions in PAH patients evaluated by echocardiography [308]. Additionally, cardiac magnetic resonance imaging demonstrates that the $\mathrm{XO}$ inhibitor, allopurinol, alleviates right ventricular hypertrophy in COPD-associated PH patients with severe airflow limitation [139]. However, in both trials, standard clinical cardiac function biomarkers, such as 6-minite walk distance and brain natriuretic peptide (BNP) levels, are not affected [139,308].

To our knowledge, these are the only available clinical trials $[139,305,306,308]$ aimed at addressing the therapeutic potential of antioxidation strategies in $\mathrm{PH} / \mathrm{PAH}$ to now. It is important to note that epoprostenol [305] and rhACE2 [306] used in clinical trials do not act primarily as antioxidants, and other classical antioxidants including SOD memetic and SOD/catalase mimetic have not been studied yet. Also, these pilot clinical trials have relatively small cohorts and fail to provide clinical details about optimal dose, treatment protocol, side effects and population generalizability. Therefore, multicenter double-blinded randomized controlled clinical trials are needed before drawing a firm conclusion about the therapeutic value of antioxidants in pulmonary hypertension.

Author Contributions: Writing-original draft preparation, S.Y.; writing-review and editing, S.Y., T.C.R. and N.L.J.; visualization, S.Y.; supervision, T.C.R. and N.L.J.; funding acquisition, T.C.R. and N.L.J. All authors have read and agreed to the published version of the manuscript. 
Funding: This work was supported by R01 HL 132883 to T.C.R. and R01 HL 111084 to N.L.J.

Conflicts of Interest: The authors declare no conflict of interest.

\section{Abbreviations}

\begin{tabular}{|c|c|}
\hline$\left[\mathrm{Ca}^{2+}\right]_{\mathrm{i}}$ & Intracellular $\mathrm{Ca}^{2+}$ level \\
\hline $5-\mathrm{HT}$ & Serotonin \\
\hline ASIC & Acid-sensing ion channel \\
\hline $\mathrm{BH} 2$ & Dihydrobiopterin \\
\hline $\mathrm{BH} 4$ & Tetrahydrobiopterin \\
\hline $\mathrm{BK}_{\mathrm{Ca}}$ & Large conductance $\mathrm{Ca}^{2+}$-activated $\mathrm{K}^{+}$channels \\
\hline $\mathrm{BNP}$ & Brain natriuretic peptide \\
\hline $\mathrm{Ca}^{2+}$ & Calcium \\
\hline $\mathrm{CH}$ & Chronic hypoxia \\
\hline COPD & Chronic obstructive pulmonary disease \\
\hline CoQ & Coenzyme Q \\
\hline DAG & Diacylglycerol \\
\hline DTNB & 5,5'-Dithiobis(2-nitrobenzoic acid) \\
\hline DTT & Dithiothreitol \\
\hline $\mathrm{EC}$ & Endothelial cell \\
\hline EGFR & Epidermal growth factor receptor \\
\hline eNOS & Endothelial nitric oxide synthase \\
\hline ET-1 & Endothelin-1 \\
\hline ETC & Electron transport chain \\
\hline FAD & Flavin adenine dinucleotide \\
\hline GPCR & G protein coupled receptor \\
\hline GSH & Reduced glutathione \\
\hline GSSG & Oxidized glutathione \\
\hline $\mathrm{H}_{2} \mathrm{O}_{2}$ & Hydrogen peroxide \\
\hline HPV & Hypoxic pulmonary vasoconstriction \\
\hline $\mathrm{IK}_{\mathrm{Ca}}$ & Intermediate conductance $\mathrm{Ca}^{2+}$-activated $\mathrm{K}^{+}$channels \\
\hline $\mathrm{IP}_{3}$ & Inositol triphosphate \\
\hline $\mathrm{K}^{+}$ & Potassium \\
\hline $\mathrm{K}_{2 \mathrm{P}}$ & Four transmembrane segments- 2 pores $\mathrm{K}^{+}$channels \\
\hline $\mathrm{K}_{\mathrm{ATP}}$ & ATP-sensitive $\mathrm{K}^{+}$channels \\
\hline $\mathrm{K}_{\mathrm{Ca}}$ & $\mathrm{Ca}^{2+}$-activated $\mathrm{K}^{+}$channels \\
\hline $\mathrm{KO}$ & Knockout \\
\hline $\mathrm{K}_{\mathrm{V}}$ & Voltage-gated $\mathrm{K}^{+}$channels \\
\hline $\mathrm{MAO}$ & Monoamine oxidase \\
\hline MitoROS & Mitochondria-derived ROS \\
\hline MLCK & Myosin light chain kinase \\
\hline MLCP & Myosin light chain phosphatase \\
\hline mPAP & Mean pulmonary arterial pressure \\
\hline MSC & Mechanosensitive channel \\
\hline MYPT1 & Myosin phosphatase target subunit 1 \\
\hline $\mathrm{Na}^{+}$ & Sodium \\
\hline NADPH & Reduced nicotinamide adenine dinucleotide phosphate \\
\hline $\mathrm{NO}$ & Nitric oxide \\
\hline NOX & NADPH oxidase \\
\hline $\mathrm{O}_{2}^{\cdot-}$ & Superoxide anion \\
\hline $\mathrm{ONOO}^{-}$ & Peroxynitrite ion \\
\hline PA & Pulmonary artery \\
\hline PAEC & Pulmonary arterial endothelial cell \\
\hline PAH & Pulmonary arterial hypertension \\
\hline PASMC & Pulmonary arterial smooth muscle cell \\
\hline
\end{tabular}




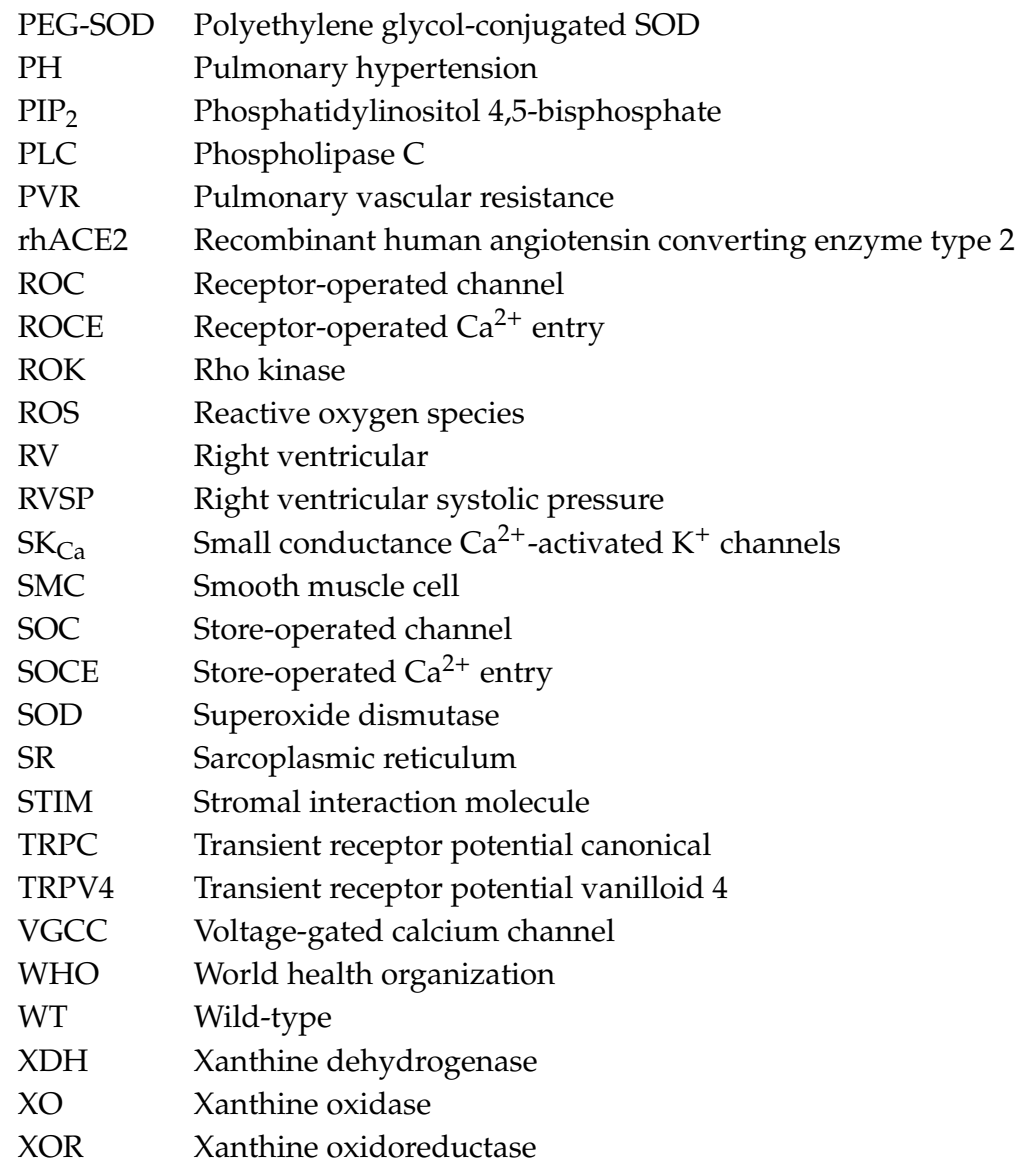

\section{References}

1. Simonneau, G.; Montani, D.; Celermajer, D.S.; Denton, C.P.; Gatzoulis, M.A.; Krowka, M.; Williams, P.G.; Souza, R. Haemodynamic definitions and updated clinical classification of pulmonary hypertension. Eur. Respir. J. 2019, 53, 1801913. [CrossRef]

2. Brown, L.M.; Chen, H.; Halpern, S.; Taichman, D.; McGoon, M.D.; Farber, H.W.; Frost, A.E.; Liou, T.G.; Turner, M.; Feldkircher, K.; et al. Delay in recognition of pulmonary arterial hypertension: Factors identified from the REVEAL Registry. Chest 2011, 140, 19-26. [CrossRef]

3. Jernigan, N.L.; Naik, J.S.; Weise-Cross, L.; Detweiler, N.D.; Herbert, L.M.; Yellowhair, T.R.; Resta, T.C. Contribution of reactive oxygen species to the pathogenesis of pulmonary arterial hypertension. PLOS ONE 2017, 12, e0180455. [CrossRef] [PubMed]

4. Stenmark, K.R.; Fagan, K.A.; Frid, M.G. Hypoxia-Induced Pulmonary Vascular Remodeling. Circ. Res. 2006, 99, 675-691. [CrossRef] [PubMed]

5. Young, J.M.; Williams, D.R.; Thompson, A.A.R. Thin Air, Thick Vessels: Historical and Current Perspectives on Hypoxic Pulmonary Hypertension. Front. Med. (Lausanne) 2019, 6, 93. [CrossRef]

6. Cahill, E.; Rowan, S.C.; Sands, M.; Banahan, M.; Ryan, D.; Howell, K.; McLoughlin, P. The pathophysiological basis of chronic hypoxic pulmonary hypertension in the mouse: Vasoconstrictor and structural mechanisms contribute equally. Exp. Physiol. 2012, 97, 796-806. [CrossRef] [PubMed]

7. Shimoda, L.A.; Sham, J.S.; Sylvester, J.T. Altered pulmonary vasoreactivity in the chronically hypoxic lung. Physiol. Res. 2000, 49, 549-560. [PubMed]

8. Jernigan, N.L.; Resta, T.C. Calcium Homeostasis and Sensitization in Pulmonary Arterial Smooth Muscle. Microcirculation 2014, 21, 259-271. [CrossRef] [PubMed]

9. Resta, T.C.; Broughton, B.R.S.; Jernigan, N.L. Reactive oxygen species and RhoA signaling in vascular smooth muscle: Role in chronic hypoxia-induced pulmonary hypertension. Adv. Exp. Med. Biol. 2010, 661, 355-373. [CrossRef] 
10. Stenmark, K.R.; McMurtry, I.F. Vascular remodeling versus vasoconstriction in chronic hypoxic pulmonary hypertension: A time for reappraisal? Circ. Res. 2005, 97, 95-98. [CrossRef]

11. Undem, C.; Luke, T.; Shimoda, L.A. Contribution of elevated intracellular calcium to pulmonary arterial myocyte alkalinization during chronic hypoxia. Pulm. Circ. 2016, 6, 93-102. [CrossRef] [PubMed]

12. Jernigan, N.L.; Walker, B.R.; Resta, T.C. Reactive oxygen species mediate RhoA/Rho kinase-induced Ca2+ sensitization in pulmonary vascular smooth muscle following chronic hypoxia. Am. J. Physiol. Lung Cell. Mol. Physiol. 2008, 295, L515-L529. [CrossRef] [PubMed]

13. Gilbert, G.; Ducret, T.; Marthan, R.; Savineau, J.-P.; Quignard, J.-F. Stretch-induced Ca ${ }^{2+}$ signalling in vascular smooth muscle cells depends on $\mathrm{Ca}^{2+}$ store segregation. Cardiovasc. Res. 2014, 103, 313-323. [CrossRef] [PubMed]

14. Wang, J.; Xu, C.; Zheng, Q.; Yang, K.; Lai, N.; Wang, T.; Wang, J.; Lu, W. Orai1, 2, 3 and STIM1 promote store-operated calcium entry in pulmonary arterial smooth muscle cells. Cell Death Discov. 2017, 3, 17074. [CrossRef]

15. Jernigan, N.L.; Paffett, M.L.; Walker, B.R.; Resta, T.C. ASIC1 contributes to pulmonary vascular smooth muscle store-operated Ca2+ entry. Am. J. Physiol. Lung Cell. Mol. Physiol. 2009, 297, L271-L285. [CrossRef]

16. Herbert, L.M.; Resta, T.C.; Jernigan, N.L. RhoA increases ASIC1a plasma membrane localization and calcium influx in pulmonary arterial smooth muscle cells following chronic hypoxia. Am. J. Physiol. Cell. Physiol. 2018, 314, C166-C176. [CrossRef]

17. Jernigan, N.L.; Herbert, L.M.; Walker, B.R.; Resta, T.C. Chronic hypoxia upregulates pulmonary arterial ASIC1: A novel mechanism of enhanced store-operated Ca2+ entry and receptor-dependent vasoconstriction. Am. J. Physiol. Cell. Physiol. 2012, 302, C931-C940. [CrossRef]

18. Norton, C.E.; Broughton, B.R.; Jernigan, N.L.; Walker, B.R.; Resta, T.C. Enhanced depolarization-induced pulmonary vasoconstriction following chronic hypoxia requires EGFR-dependent activation of NAD(P)H oxidase 2. Antioxid. Redox Signal. 2013, 18, 1777-1788. [CrossRef]

19. Weise-Cross, L.; Sands, M.A.; Sheak, J.R.; Broughton, B.R.S.; Snow, J.B.; Bosc, L.V.G.; Jernigan, N.L.; Walker, B.R.; Resta, T.C. Actin polymerization contributes to enhanced pulmonary vasoconstrictor reactivity after chronic hypoxia. Am. J. Physiol. Heart Circ. Physiol. 2018, 314, H1011-H1021. [CrossRef]

20. Broughton, B.R.S.; Jernigan, N.L.; Norton, C.E.; Walker, B.R.; Resta, T.C. Chronic hypoxia augments depolarization-induced $\mathrm{Ca} 2+$ sensitization in pulmonary vascular smooth muscle through superoxide-dependent stimulation of RhoA. Am. J. Physiol. Lung Cell. Mol. Physiol. 2010, 298, L232-L242. [CrossRef]

21. Broughton, B.R.S.; Walker, B.R.; Resta, T.C. Chronic hypoxia induces Rho kinase-dependent myogenic tone in small pulmonary arteries. Am. J. Physiol. Lung Cell. Mol. Physiol. 2008, 294, L797-L806. [CrossRef] [PubMed]

22. Norton, C.E.; Sheak, J.R.; Yan, S.; Weise-Cross, L.; Jernigan, N.L.; Walker, B.R.; Resta, T.C. Augmented Pulmonary Vasoconstrictor Reactivity after Chronic Hypoxia Requires Src Kinase and Epidermal Growth Factor Receptor Signaling. Am. J. Respir. Cell Mol. Biol. 2020, 62, 61-73. [CrossRef]

23. Budhiraja, R.; Tuder, R.M.; Hassoun, P.M. Endothelial Dysfunction in Pulmonary Hypertension. Circulation 2004, 109, 159-165. [CrossRef]

24. Liu, J.Q.; Erbynn, E.M.; Folz, R.J. Chronic hypoxia-enhanced murine pulmonary vasoconstriction: Role of superoxide and gp91phox. Chest 2005, 128 (Suppl. S6), 594S-596S. [CrossRef]

25. Mackay, C.E.; Shaifta, Y.; Snetkov, V.V.; Francois, A.A.; Ward, J.P.; A Knock, G. ROS-dependent activation of RhoA/Rho-kinase in pulmonary artery: Role of Src-family kinases and ARHGEF1. Free Radic. Biol. Med. 2017, 110, 316-331. [CrossRef]

26. Jernigan, N.L.; Walker, B.R.; Resta, T.C. Endothelium-derived reactive oxygen species and endothelin-1 attenuate NO-dependent pulmonary vasodilation following chronic hypoxia. Am. J. Physiol. Lung Cell. Mol. Physiol. 2004, 287, L801-L808. [CrossRef]

27. Knock, G.A.; Snetkov, V.A.; Shaifta, Y.; Connolly, M.; Drndarski, S.; Noah, A.; Pourmahram, G.E.; Becker, S.; Aaronson, P.I.; Ward, J.P. Superoxide constricts rat pulmonary arteries via Rho-kinase-mediated $\mathrm{Ca}(2+)$ sensitization. Free Radic. Biol. Med. 2009, 46, 633-642. [CrossRef] [PubMed]

28. Plomaritas, D.R.; Herbert, L.M.; Yellowhair, T.R.; Resta, T.C.; Bosc, L.V.G.; Walker, B.R.; Jernigan, N.L. Chronic hypoxia limits $\mathrm{H} 2 \mathrm{O} 2$-induced inhibition of ASIC1-dependent store-operated calcium entry in pulmonary arterial smooth muscle. Am. J. Physiol. Lung Cell. Mol. Physiol. 2014, 307, 419-430. [CrossRef] 
29. Adesina, S.E.; Kang, B.-Y.; Bijli, K.M.; Ma, J.; Cheng, J.; Murphy, T.C.; Hart, C.M.; Sutliff, R.L. Targeting mitochondrial reactive oxygen species to modulate hypoxia-induced pulmonary hypertension. Free Radic. Biol. Med. 2015, 87, 36-47. [CrossRef]

30. Ahmed, M.N.; Zhang, Y.; Codipilly, C.; Zaghloul, N.; Patel, D.; Wolin, M.; Miller, E.J. Extracellular Superoxide Dismutase Overexpression Can Reverse the Course of Hypoxia-Induced Pulmonary Hypertension. Mol. Med. 2012, 18, 38-46. [CrossRef] [PubMed]

31. Dikalova, A.; Aschner, J.L.; Kaplowitz, M.R.; Summar, M.; Fike, C.D. Tetrahydrobiopterin oral therapy recouples eNOS and ameliorates chronic hypoxia-induced pulmonary hypertension in newborn pigs. Am. J. Physiol. Lung Cell. Mol. Physiol. 2016, 311, L743-L753. [CrossRef] [PubMed]

32. Elmedal, B.; De Dam, M.Y.; Mulvany, M.J.; Simonsen, U. The superoxide dismutase mimetic, tempol, blunts right ventricular hypertrophy in chronic hypoxic rats. Br. J. Pharmacol. 2004, 141, 105-113. [CrossRef] [PubMed]

33. Fike, C.D.; Dikalova, A.; Slaughter, J.C.; Kaplowitz, M.; Zhang, Y.; Aschner, J.L. Reactive Oxygen Species-Reducing Strategies Improve Pulmonary Arterial Responses to Nitric Oxide in Piglets with Chronic Hypoxia-Induced Pulmonary Hypertension. Antioxid. Redox Signal. 2013, 18, 1727-1738. [CrossRef] [PubMed]

34. Francis, B.N.; Hale, A.; Channon, K.M.; Wilkins, M.R.; Zhao, L. Effects of tetrahydrobiopterin oral treatment in hypoxia-induced pulmonary hypertension in rat. Pulm. Circ. 2014, 4, 462-470. [CrossRef] [PubMed]

35. Hoshikawa, Y.; Ono, S.; Suzuki, S.; Tanita, T.; Chida, M.; Song, C.; Noda, M.; Tabata, T.; Voelkel, N.F.; Fujimura, S. Generation of oxidative stress contributes to the development of pulmonary hypertension induced by hypoxia. J. Appl. Physiol. 2001, 90, 1299-1306. [CrossRef]

36. Jankov, R.P.; Kantores, C.; Pan, J.; Belik, J. Contribution of xanthine oxidase-derived superoxide to chronic hypoxic pulmonary hypertension in neonatal rats. Am. J. Physiol. Lung Cell. Mol. Physiol. 2008, 294, L233-L245. [CrossRef]

37. Villegas, L.R.; Kluck, D.; Field, C.; Oberley-Deegan, R.E.; Woods, C.; Yeager, M.E.; El Kasmi, K.C.; Savani, R.C.; Bowler, R.P.; Nozik-Grayck, E. Superoxide Dismutase Mimetic, MnTE-2-PyP, Attenuates Chronic Hypoxia-Induced Pulmonary Hypertension, Pulmonary Vascular Remodeling, and Activation of the NALP3 Inflammasome. Antioxid. Redox Signal. 2013, 18, 1753-1764. [CrossRef]

38. Fukai, T.; Ushio-Fukai, M. Superoxide Dismutases: Role in Redox Signaling, Vascular Function, and Diseases. Antioxid. Redox Signal. 2011, 15, 1583-1606. [CrossRef] [PubMed]

39. Petry, A.; Djordjevic, T.; Weitnauer, M.; Kietzmann, T.; Hess, J.; Görlach, A. NOX2 and NOX4 Mediate Proliferative Response in Endothelial Cells. Antioxid. Redox Signal. 2006, 8, 1473-1484. [CrossRef]

40. Abid, M.R.; Kachra, Z.; Spokes, K.C.; Aird, W.C. NADPH oxidase activity is required for endothelial cell proliferation and migration. FEBS Lett. 2000, 486, 252-256. [CrossRef]

41. Clempus, R.E.; Sorescu, D.; Dikalova, A.E.; Pounkova, L.; Jo, P.; Sorescu, G.P.; Schmidt, H.H.H.; Lassègue, B.; Griendling, K.K. Nox4 is required for maintenance of the differentiated vascular smooth muscle cell phenotype. Arter. Thromb. Vasc. Biol. 2007, 27, 42-48. [CrossRef] [PubMed]

42. Yada, T. Hydrogen Peroxide, an Endogenous Endothelium-Derived Hyperpolarizing Factor, Plays an Important Role in Coronary Autoregulation In Vivo. Circulation 2003, 107, 1040-1045. [CrossRef] [PubMed]

43. Sindler, A.L.; Reyes, R.; Chen, B.; Ghosh, P.; Gurovich, A.N.; Kang, L.S.; Cardounel, A.J.; Delp, M.D.; Muller-Delp, J. Age and exercise training alter signaling through reactive oxygen species in the endothelium of skeletal muscle arterioles. J. Appl. Physiol. 2013, 114, 681-693. [CrossRef]

44. Muñoz, M.; Martínez, M.P.; López-Oliva, M.E.; Rodríguez, C.; Corbacho, C.; Carballido, J.; García-Sacristán, A.; Hernández, M.; Rivera, L.; Medina, J.S.; et al. Hydrogen peroxide derived from NADPH oxidase 4- and 2 contributes to the endothelium-dependent vasodilatation of intrarenal arteries. Redox Biol. 2018, 19, 92-104. [CrossRef] [PubMed]

45. Drouin, A.; Thorin, E. Flow-induced dilation is mediated by Akt-dependent activation of endothelial nitric oxide synthase-derived hydrogen peroxide in mouse cerebral arteries. Stroke 2009, 40, 1827-1833. [CrossRef]

46. Ahmad, M.; Kelly, M.R.; Zhao, X.; Kandhi, S.; Wolin, M.S. Roles for Nox4 in the contractile response of bovine pulmonary arteries to hypoxia. Am. J. Physiol. Heart Circ. Physiol. 2010, 298, H1879-H1888. [CrossRef] [PubMed] 
47. Murtaza, G.; Paddenberg, R.; Pfeil, U.; Goldenberg, A.; Mermer, P.; Kummer, W. Hypoxia-induced pulmonary vasoconstriction of intra-acinar arteries is impaired in NADPH oxidase 4 gene-deficient mice. Pulm. Circ. 2018, 8, 2045894018808240. [CrossRef]

48. Mak, S.; Egri, Z.; Tanna, G.; Colman, R.; Newton, G.E. Vitamin C prevents hyperoxia-mediated vasoconstriction and impairment of endothelium-dependent vasodilation. Am. J. Physiol. Heart Circ. Physiol. 2002, 282, H2414-H2421. [CrossRef]

49. Rousseau, A.; Tesselaar, E.; Henricson, J.; Sjöberg, F. Prostaglandins and Radical Oxygen Species Are Involved in Microvascular Effects of Hyperoxia. J. Vasc. Res. 2010, 47, 441-450. [CrossRef] [PubMed]

50. Zhilyaev, S.Y.; Moskvin, A.N.; Platonova, T.F.; Gutsaeva, D.R.; Churilina, I.V.; Demchenko, I.T. Hyperoxic vasoconstriction in the brain is mediated by inactivation of nitric oxide by superoxide anions. Neurosci. Behav. Physiol. 2003, 33, 783-787. [CrossRef]

51. Burke, T.M.; Wolin, M.S. Hydrogen peroxide elicits pulmonary arterial relaxation and guanylate cyclase activation. Am. J. Physiol. Heart Circ. Physiol. 1987, 252 Pt 2, H721-H732. [CrossRef]

52. Michelakis, E.D.; Hampl, V.; Nsair, A.; Wu, X.; Harry, G.; Haromy, A.; Gurtu, R.; Archer, S.L. Diversity in Mitochondrial Function Explains Differences in Vascular Oxygen Sensing. Circ. Res. 2002, 90, 1307-1315. [CrossRef]

53. Neo, B.H.; Patel, D.; Kandhi, S.; Wolin, M.S. Roles for cytosolic NADPH redox in regulating pulmonary artery relaxation by thiol oxidation-elicited subunit dimerization of protein kinase G1 $\alpha$. Am. J. Physiol. Heart Circ. Physiol. 2013, 305, H330-H343. [CrossRef]

54. Neo, B.H.; Kandhi, S.; Wolin, M.S. Roles for soluble guanylate cyclase and a thiol oxidation-elicited subunit dimerization of protein kinase $\mathrm{G}$ in pulmonary artery relaxation to hydrogen peroxide. Am. J. Physiol. Heart Circ. Physiol. 2010, 299, H1235-H1241. [CrossRef] [PubMed]

55. Patel, D.; Alhawaj, R.; Wolin, M.S. Exposure of mice to chronic hypoxia attenuates pulmonary arterial contractile responses to acute hypoxia by increases in extracellular hydrogen peroxide. Am. J. Physiol. Regul. Integr. Comp. Physiol. 2014, 307, R426-R433. [CrossRef] [PubMed]

56. Rudyk, O.; Rowan, A.; Prysyazhna, O.; Krasemann, S.; Hartmann, K.; Zhang, M.; Shah, A.M.; Ruppert, C.; Weiss, A.; Schermuly, R.T.; et al. Oxidation of PKGI $\alpha$ mediates an endogenous adaptation to pulmonary hypertension. Proc. Natl. Acad. Sci. USA 2019, 116, 13016-13025. [CrossRef] [PubMed]

57. Wedgwood, S.; Lakshminrusimha, S.; Fukai, T.; Russell, J.A.; Schumacker, P.T.; Steinhorn, R. Hydrogen Peroxide Regulates Extracellular Superoxide Dismutase Activity and Expression in Neonatal Pulmonary Hypertension. Antioxid. Redox Signal. 2011, 15, 1497-1506. [CrossRef] [PubMed]

58. Wedgwood, S.; Steinhorn, R.; Bunderson, M.; Wilham, J.; Lakshminrusimha, S.; Brennan, L.A.; Black, S.M. Increased hydrogen peroxide downregulates soluble guanylate cyclase in the lungs of lambs with persistent pulmonary hypertension of the newborn. Am. J. Physiol. Lung Cell. Mol. Physiol. 2005, 289, L660-L666. [CrossRef]

59. Jernigan, N.L.; Resta, T.C.; Walker, B.R. Contribution of oxygen radicals to altered NO-dependent pulmonary vasodilation in acute and chronic hypoxia. Am. J. Physiol. Lung Cell. Mol. Physiol. 2004, 286, L947-L955. [CrossRef] [PubMed]

60. Nozik-Grayck, E.; Stenmark, K.R. Role of reactive oxygen species in chronic hypoxia-induced pulmonary hypertension and vascular remodeling. Adv. Exp. Med. Biol. 2007, 618, 101-112. [CrossRef] [PubMed]

61. Ravi, Y.; Selvendiran, K.; Naidu, S.K.; Meduru, S.; Citro, L.A.; Bognár, B.; Khan, M.; Kálai, T.; Hideg, K.; Kuppusamy, M.L.; et al. Pulmonary hypertension secondary to left-heart failure involves peroxynitrite-induced downregulation of PTEN in the lung. Hypertension 2013, 61, 593-601. [CrossRef] [PubMed]

62. Zhao, Y.-Y.; Zhao, Y.D.; Mirza, M.K.; Huang, J.H.; Potula, H.-H.S.; Vogel, S.M.; Brovkovych, V.; Yuan, J.X.-J.; Wharton, J.; Malik, A.B. Persistent eNOS activation secondary to caveolin-1 deficiency induces pulmonary hypertension in mice and humans through PKG nitration. J. Clin. Investig. 2009, 119, 2009-2018. [CrossRef] [PubMed]

63. Oishi, P.; Grobe, A.; Benavidez, E.; Ovadia, B.; Harmon, C.; Ross, G.A.; Hendricks-Munoz, K.; Xu, J.; Black, S.M.; Fineman, J.R. Inhaled nitric oxide induced NOS inhibition and rebound pulmonary hypertension: A role for superoxide and peroxynitrite in the intact lamb. Am. J. Physiol. Lung Cell. Mol. Physiol. 2006, 290, L359-L366. [CrossRef] [PubMed] 
64. Vara, D.; Pula, G. Reactive oxygen species: Physiological roles in the regulation of vascular cells. Curr. Mol. Med. 2014, 14, 1103-1125. [CrossRef] [PubMed]

65. Perez-Vizcaino, F.; Cogolludo, A.; Moreno, L. Reactive oxygen species signaling in pulmonary vascular smooth muscle. Respir. Physiol. Neurobiol. 2010, 174, 212-220. [CrossRef] [PubMed]

66. Raaz, U.; Toh, R.; Maegdefessel, L.; Adam, M.; Nakagami, F.; Emrich, F.C.; Spin, J.M.; Tsao, P.S. Hemodynamic Regulation of Reactive Oxygen Species: Implications for Vascular Diseases. Antioxid. Redox Signal. 2014, 20, 914-928. [CrossRef] [PubMed]

67. Krylatov, A.V.; Maslov, L.N.; Voronkov, N.; Boshchenko, A.; Popov, S.V.; Gomez, L.; Wang, H.; Jaggi, A.S.; Downey, J.M. Reactive Oxygen Species as Intracellular Signaling Molecules in the Cardiovascular System. Curr. Cardiol. Rev. 2018, 14, 290-300. [CrossRef]

68. Burgoyne, J.R.; Mongue-Din, H.; Eaton, P.; Shah, A.M. Redox Signaling in Cardiac Physiology and Pathology. Circ. Res. 2012, 111, 1091-1106. [CrossRef]

69. Burgoyne, J.R.; Oka, S.-I.; Ale-Agha, N.; Eaton, P. Hydrogen Peroxide Sensing and Signaling by Protein Kinases in the Cardiovascular System. Antioxid. Redox Signal. 2013, 18, 1042-1052. [CrossRef]

70. Spickett, C.M.; Pitt, A.R.; Morrice, N.; Kolch, W. Proteomic analysis of phosphorylation, oxidation and nitrosylation in signal transduction. Biochim. Biophys. Acta 2006, 1764, 1823-1841. [CrossRef]

71. Tang, H.; Viola, H.M.; Filipovska, A.; Hool, L.C. Cav1.2 calcium channel is glutathionylated during oxidative stress in guinea pig and ischemic human heart. Free Radic. Biol. Med. 2011, 51, 1501-1511. [CrossRef] [PubMed]

72. Johnstone, V.P.A.; Hool, L.C. Glutathionylation of the L-type Ca2+ Channel in Oxidative Stress-Induced Pathology of the Heart. Int. J. Mol. Sci. 2014, 15, 19203-19225. [CrossRef] [PubMed]

73. Hawkins, B.J.; Irrinki, K.M.; Mallilankaraman, K.; Lien, Y.-C.; Wang, Y.; Bhanumathy, C.D.; Subbiah, R.; Ritchie, M.F.; Soboloff, J.; Baba, Y.; et al. S-glutathionylation activates STIM1 and alters mitochondrial homeostasis. J. Cell Biol. 2010, 190, 391-405. [CrossRef]

74. Zha, X.-M.; Wang, R.; Collier, D.M.; Snyder, P.M.; Wemmie, J.A.; Welsh, M.J. Oxidant regulated inter-subunit disulfide bond formation between ASIC1a subunits. Proc. Natl. Acad. Sci. USA 2009, 106, 3573-3578. [CrossRef]

75. Wu, X.; Hernandez-Enriquez, B.; Banas, M.; Xu, R.; Sesti, F. Molecular Mechanisms Underlying the Apoptotic Effect of KCNB1 K+ Channel Oxidation. J. Biol. Chem. 2013, 288, 4128-4134. [CrossRef] [PubMed]

76. Cotella, D.; Hernandez-Enriquez, B.; Wu, X.; Li, R.; Pan, Z.; Leveille, J.; Link, C.D.; Oddo, S.; Sesti, F. Toxic Role of K+ Channel Oxidation in Mammalian Brain. J. Neurosci. 2012, 32, 4133-4144. [CrossRef] [PubMed]

77. Heo, J.; Raines, K.W.; Mocanu, V.; Campbell, S.L. Redox Regulation of RhoA. Biochemistry 2006, 45, 14481-14489. [CrossRef]

78. Svoboda, L.K.; Reddie, K.G.; Zhang, L.; Vesely, E.D.; Williams, E.S.; Schumacher, S.M.; O'Connell, R.P.; Shaw, R.M.; Day, S.M.; Anumonwo, J.M.; et al. Redox-sensitive sulfenic acid modification regulates surface expression of the cardiovascular voltage-gated potassium channel Kv1.5. Circ. Res. 2012, 111, 842-853. [CrossRef]

79. Panday, A.; Sahoo, M.K.; Osorio, D.; Batra, S. NADPH oxidases: An overview from structure to innate immunity-associated pathologies. Cell. Mol. Immunol. 2015, 12, 5-23. [CrossRef]

80. Nguyen, G.T.; Green, E.R.; Mecsas, J. Neutrophils to the ROScue: Mechanisms of NADPH Oxidase Activation and Bacterial Resistance. Front. Cell Infect. Microbiol. 2017, 7, 373. [CrossRef] [PubMed]

81. Menden, H.; Tate, E.; Hogg, N.; Sampath, V. LPS-mediated endothelial activation in pulmonary endothelial cells: Role of Nox2-dependent IKK- $\beta$ phosphorylation. Am. J. Physiol. Lung Cell. Mol. Physiol. 2013, 304, L445-L455. [CrossRef] [PubMed]

82. Pendyala, S.; A Gorshkova, I.; Usatyuk, P.V.; He, D.; Pennathur, A.; Lambeth, J.D.; Thannickal, V.J.; Natarajan, V. Role of Nox4 and Nox2 in Hyperoxia-Induced Reactive Oxygen Species Generation and Migration of Human Lung Endothelial Cells. Antioxid. Redox Signal. 2009, 11, 747-764. [CrossRef] [PubMed]

83. Ghouleh, I.A.; Sahoo, S.; Meijles, D.N.; Amaral, J.H.; De Jesus, D.S.; Sembrat, J.; Rojas, M.; Goncharov, D.A.; Goncharova, E.A.; Pagano, P.J. Endothelial Nox1 oxidase assembly in human pulmonary arterial hypertension; driver of Gremlin1-mediated proliferation. Clin. Sci. (Lond.) 2017, 131, 2019-2035. [CrossRef] [PubMed]

84. Chignalia, A.Z.; Weinberg, G.; Dull, R. Norepinephrine Induces Lung Microvascular Endothelial Cell Death by NADPH Oxidase-Dependent Activation of Caspase-3. Oxidative Med. Cell. Longev. 2020, 2020, 2563764. [CrossRef] 
85. Hood, K.Y.; Mair, K.M.; Harvey, A.P.; Montezano, A.C.; Touyz, R.M.; MacLean, M.R. Serotonin Signaling Through the 5-HT(1B) Receptor and NADPH Oxidase 1 in Pulmonary Arterial Hypertension. Arterioscler. Thromb. Vasc. Biol. 2017, 37, 1361-1370. [CrossRef]

86. Yu, W.; Ji, W.; Mi, L.; Lin, C. Mechanisms of N-acetylcysteine in reducing monocrotaline-induced pulmonary hypertension in rats: Inhibiting the expression of Nox1 in pulmonary vascular smooth muscle cells. Mol. Med. Rep. 2017, 16, 6148-6155. [CrossRef]

87. Veit, F.; Pak, O.; Egemnazarov, B.; Roth, M.; Kosanovic, D.; Seimetz, M.; Sommer, N.; Ghofrani, H.-A.; Seeger, W.; Grimminger, F.; et al. Function of NADPH Oxidase 1 in Pulmonary Arterial Smooth Muscle Cells After Monocrotaline-Induced Pulmonary Vascular Remodeling. Antioxid. Redox Signal. 2013, 19, 2213-2231. [CrossRef]

88. Iwata, K.; Ikami, K.; Matsuno, K.; Yamashita, T.; Shiba, D.; Ibi, M.; Misaki, M.; Masato, K.; Wenhao, C.; Jia, Z.; et al. Deficiency of NOX1/Nicotinamide Adenine Dinucleotide Phosphate, Reduced Form Oxidase Leads to Pulmonary Vascular Remodeling. Arterioscler. Thromb. Vasc. Biol. 2014, 34, 110-119. [CrossRef]

89. Hendricks, K.; To, E.; Vlahos, R.; Broughton, B.; Peshavariya, H.; Selemidis, S. Influenza A virus causes vascular endothelial cell oxidative stress via NOX2 oxidase. Eur. Respir. J. 2016, 48 (Suppl. S60), PA3967. [CrossRef]

90. Mittal, M.; Roth, M.; König, P.; Hofmann, S.; Dony, E.; Goyal, P.; Selbitz, A.-C.; Schermuly, R.T.; Ghofrani, H.A.; Kwapiszewska, G.; et al. Hypoxia-Dependent Regulation of Nonphagocytic NADPH Oxidase Subunit NOX4 in the Pulmonary Vasculature. Circ. Res. 2007, 101, 258-267. [CrossRef]

91. Gandhirajan, R.K.; Meng, S.; Chandramoorthy, H.C.; Mallilankaraman, K.; Mancarella, S.; Gao, H.; Razmpour, R.; Yang, X.-F.; Houser, S.R.; Chen, J.; et al. Blockade of NOX2 and STIM1 signaling limits lipopolysaccharide-induced vascular inflammation. J. Clin. Investig. 2013, 123, 887-902. [CrossRef] [PubMed]

92. Li, T.; Luo, X.-J.; Wang, E.-L.; Li, N.-S.; Zhang, X.-J.; Song, F.-L.; Yang, J.-F.; Liu, B.; Peng, J. Magnesium lithospermate B prevents phenotypic transformation of pulmonary arteries in rats with hypoxic pulmonary hypertension through suppression of NADPH oxidase. Eur. J. Pharmacol. 2019, 847, 32-41. [CrossRef] [PubMed]

93. Bánfi, B.; Malgrange, B.; Knisz, J.; Steger, K.; Dubois-Dauphin, M.; Krause, K.-H. NOX3, a Superoxide-generating NADPH Oxidase of the Inner Ear. J. Biol. Chem. 2004, 279, 46065-46072. [CrossRef] [PubMed]

94. Goitre, L.; Distefano, P.V.; Moglia, A.; Nobiletti, N.; Baldini, E.; Trabalzini, L.; Keubel, J.; Trapani, E.; Shuvaev, V.V.; Muzykantov, V.R.; et al. Up-regulation of NADPH oxidase-mediated redox signaling contributes to the loss of barrier function in KRIT1 deficient endothelium. Sci. Rep. 2017, 7, 8296. [CrossRef] [PubMed]

95. Schröder, K.; Zhang, M.; Benkhoff, S.; Mieth, A.; Pliquett, R.; Kosowski, J.; Kruse, C.; Luedike, P.; Michaelis, U.R.; Weissmann, N.; et al. Nox4 Is a Protective Reactive Oxygen Species Generating Vascular NADPH Oxidase. Circ. Res. 2012, 110, 1217-1225. [CrossRef] [PubMed]

96. Ismail, S.; Sturrock, A.; Wu, P.; Cahill, B.; Norman, K.; Huecksteadt, T.; Sanders, K.; Kennedy, T.; Hoidal, J. NOX4 mediates hypoxia-induced proliferation of human pulmonary artery smooth muscle cells: The role of autocrine production of transforming growth factor- $\beta 1$ and insulin-like growth factor binding protein-3. Am. J. Physchol. Lung Cell. Mol. Physchol. 2009, 296, L489-L499. [CrossRef] [PubMed]

97. Diebold, I.; Petry, A.; Hess, J.; Görlach, A. The NADPH Oxidase Subunit NOX4 Is a New Target Gene of the Hypoxia-inducible Factor-1. Mol. Biol. Cell 2010, 21, 2087-2096. [CrossRef]

98. Hood, K.Y.; Montezano, A.C.; Harvey, A.P.; Nilsen, M.; MacLean, M.R.; Touyz, R.M. Nicotinamide Adenine Dinucleotide Phosphate Oxidase-Mediated Redox Signaling and Vascular Remodeling by $16 \alpha$-Hydroxyestrone in Human Pulmonary Artery Cells: Implications in Pulmonary Arterial Hypertension. Hypertension 2016, 68, 796-808. [CrossRef]

99. Martyn, K.D.; Frederick, L.M.; Von Loehneysen, K.; Dinauer, M.C.; Knaus, U.G. Functional analysis of Nox4 reveals unique characteristics compared to other NADPH oxidases. Cell. Signal. 2006, 18, 69-82. [CrossRef]

100. Nisimoto, Y.; Jackson, H.M.; Ogawa, H.; Kawahara, T.; Lambeth, J.D. Constitutive NADPH-Dependent Electron Transferase Activity of the Nox4 Dehydrogenase Domain. Biochemistry 2010, 49, 2433-2442. [CrossRef]

101. Nisimoto, Y.; Diebold, B.A.; Cosentino-Gomes, D.; Constentino-Gomes, D.; Lambeth, J.D. Nox4: A Hydrogen Peroxide-Generating Oxygen Sensor. Biochemistry 2014, 53, 5111-5120. [CrossRef] [PubMed] 
102. Guo, X.; Fan, Y.; Cui, J.; Hao, B.; Zhu, L.; Sun, X.; He, J.; Yang, J.; Dong, J.; Wang, Y.; et al. NOX4 expression and distal arteriolar remodeling correlate with pulmonary hypertension in COPD. BMC Pulm. Med. 2018, 18, 111. [CrossRef]

103. Veith, C.; Kraut, S.; Wilhelm, J.; Sommer, N.; Quanz, K.; Seeger, W.; Brandes, R.P.; Weissmann, N.; Schröder, K. NADPH oxidase 4 is not involved in hypoxia-induced pulmonary hypertension. Pulm. Circ. 2016, 6, 397-400. [CrossRef] [PubMed]

104. Ray, R.; Murdoch, C.E.; Wang, M.; Santos, C.X.; Zhang, M.; Alom-Ruiz, S.; Anilkumar, N.; Ouattara, A.; Cave, A.C.; Walker, S.J.; et al. Endothelial Nox4 NADPH Oxidase Enhances Vasodilatation and Reduces Blood Pressure In Vivo. Arter. Thromb. Vasc. Biol. 2011, 31, 1368-1376. [CrossRef] [PubMed]

105. Zhang, M.; Mongue-Din, H.; Martin, D.; Catibog, N.; Smyrnias, I.; Zhang, X.; Yu, B.; Wang, M.; Brandes, R.P.; Schröder, K.; et al. Both cardiomyocyte and endothelial cell Nox4 mediate protection against hemodynamic overload-induced remodelling. Cardiovasc. Res. 2018, 114, 401-408. [CrossRef]

106. Cadenas, E.; Davies, K.J.A. Mitochondrial free radical generation, oxidative stress, and aging. Free Radic. Biol. Med. 2000, 29, 222-230. [CrossRef]

107. Miriyala, S.; Holley, A.K.; Clair, D.K.S. Mitochondrial superoxide dismutase-signals of distinction. Anti Cancer Agents Med. Chem. 2011, 11, 181-190. [CrossRef]

108. Al Shahrani, M.; Heales, S.J.; Hargreaves, I.; Orford, M. Oxidative Stress: Mechanistic Insights into Inherited Mitochondrial Disorders and Parkinson's Disease. J. Clin. Med. 2017, 6, 100. [CrossRef]

109. Handy, D.E.; Lubos, E.; Yang, Y.; Galbraith, J.D.; Kelly, N.; Zhang, Y.-Y.; Leopold, J.A.; Loscalzo, J. Glutathione Peroxidase-1 Regulates Mitochondrial Function to Modulate Redox-dependent Cellular Responses. J. Biol. Chem. 2009, 284, 11913-11921. [CrossRef]

110. Yu, E.; Mercer, J.; Bennett, M.R. Mitochondria in vascular disease. Cardiovasc. Res. 2012, 95, $173-182$. [CrossRef] [PubMed]

111. Bai, J.; Cederbaum, A.I. Mitochondrial Catalase and Oxidative Injury. Biol. Signals Recept. 2001, 10, 189-199. [CrossRef] [PubMed]

112. Murphy, M.P. How mitochondria produce reactive oxygen species. Biochem. J. 2009, 417, 1-13. [CrossRef]

113. Suresh, K.; Servinsky, L.; Jiang, H.; Bigham, Z.; Yun, X.; Kliment, C.; Huetsch, J.; Damarla, M.; Shimoda, L.A. Reactive oxygen species induced $\mathrm{Ca}(2+)$ influx via TRPV4 and microvascular endothelial dysfunction in the SU5416/hypoxia model of pulmonary arterial hypertension. Am. J. Physiol. Lung Cell Mol. Physiol. 2018, 314, L893-L907. [CrossRef] [PubMed]

114. Sheak, J.R.; Yan, S.; Weise-Cross, L.; Ahmadian, R.; Walker, B.R.; Jernigan, N.L.; Resta, T.C. PKC $\beta$ and reactive oxygen species mediate enhanced pulmonary vasoconstrictor reactivity following chronic hypoxia in neonatal rats. Am. J. Physiol. Heart Circ. Physiol. 2020, 318, H470-H483. [CrossRef] [PubMed]

115. Coggins, M.P.; Bloch, K.D.; Zadelaar, S.; Kleemann, R.; Verschuren, L.; Weij, J.D.V.-V.D.; Van Der Hoorn, J.; Princen, H.M.; Kooistra, T. Nitric Oxide in the Pulmonary Vasculature. Arter. Thromb. Vasc. Biol. 2007, 27, 1877-1885. [CrossRef]

116. Vásquez-Vivar, J.; Kalyanaraman, B.; Martásek, P.; Hogg, N.; Masters, B.S.S.; Karoui, H.; Tordo, P.; Pritchard, K.A. Superoxide generation by endothelial nitric oxide synthase: The influence of cofactors. Proc. Natl. Acad. Sci. USA 1998, 95, 9220-9225. [CrossRef] [PubMed]

117. Schmidt, T.S.; Alp, N.J. Mechanisms for the role of tetrahydrobiopterin in endothelial function and vascular disease. Clin. Sci. (Lond.) 2007, 113, 47-63. [CrossRef]

118. Griffith, O.W.; Stuehr, D.J. Nitric oxide synthases: Properties and catalytic mechanism. Annu. Rev. Physiol. 1995, 57, 707-736. [CrossRef] [PubMed]

119. Habib, S.; Ali, A. Biochemistry of Nitric Oxide. Indian J. Clin. Biochem. IJCB 2011, 26, 3-17. [CrossRef] [PubMed]

120. Vásquez-Vivar, J.; Kalyanaraman, B.; Martasek, P. The role of tetrahydrobiopterin in superoxide generation from eNOS: Enzymology and physiological implications. Free Radic. Res. 2003, 37, 121-127. [CrossRef] [PubMed]

121. Crabtree, M.J.; Tatham, A.L.; Al-Wakeel, Y.; Warrick, N.; Hale, A.B.; Cai, S.; Channon, K.M.; Alp, N.J. Quantitative Regulation of Intracellular Endothelial Nitric-oxide Synthase (eNOS) Coupling by Both Tetrahydrobiopterin-eNOS Stoichiometry and Biopterin Redox Status: Insights From Cells With Tet-Regulated Gtp Cyclohydrolase I Expression. J. Biol. Chem. 2009, 284, 1136-1144. [CrossRef] [PubMed] 
122. Crabtree, M.J.; Channon, K.M. Synthesis and recycling of tetrahydrobiopterin in endothelial function and vascular disease. Nitric Oxide Biol. Chem. 2011, 25, 81-88. [CrossRef]

123. Vásquez-Vivar, J.; Martásek, P.; Whitsett, J.; Joseph, J.; Kalyanaraman, B. The ratio between tetrahydrobiopterin and oxidized tetrahydrobiopterin analogues controls superoxide release from endothelial nitric oxide synthase: An EPR spin trapping study. Biochem. J. 2002, 362 Pt 3, 733-739. [CrossRef]

124. Khoo, J.P.; Zhao, L.; Alp, N.J.; Bendall, J.K.; Nicoli, T.; Rockett, K.; Wilkins, M.R.; Channon, K.M.; Woo, A.; Williams, W.G.; et al. Pivotal Role for Endothelial Tetrahydrobiopterin in Pulmonary Hypertension. Circulation 2005, 111, 2126-2133. [CrossRef]

125. Bevers, L.M.; Braam, B.; Post, J.A.; Van Zonneveld, A.J.; Rabelink, T.J.; Koomans, H.A.; Verhaar, M.; Joles, J.A. Tetrahydrobiopterin, but Not 1 -Arginine, Decreases NO Synthase Uncoupling in Cells Expressing High Levels of Endothelial NO Synthase. Hypertension 2006, 47, 87-94. [CrossRef]

126. Edgar, K.S.; Galvin, O.M.; Collins, A.; Katusic, Z.S.; McDonald, D.M. BH4-Mediated Enhancement of Endothelial Nitric Oxide Synthase Activity Reduces Hyperoxia-Induced Endothelial Damage and Preserves Vascular Integrity in the Neonate. Investig. Opthalmology Vis. Sci. 2017, 58, 230-241. [CrossRef]

127. Schreiber, C.; Eilenberg, M.S.; Panzenboeck, A.; Winter, M.P.; Bergmeister, H.; Herzog, R.; Mascherbauer, J.; Lang, I.M.; Bonderman, D. Combined oral administration of L-arginine and tetrahydrobiopterin in a rat model of pulmonary arterial hypertension. Pulm. Circ. 2017, 7, 89-97. [CrossRef] [PubMed]

128. Sheehy, A.M.; Burson, M.A.; Black, S.M. Nitric oxide exposure inhibits endothelial NOS activity but not gene expression: A role for superoxide. Am. J. Physiol. Lung Cell. Mol. Physiol. 1998, 274, L833-L841. [CrossRef] [PubMed]

129. Wedgwood, S.; McMullan, D.M.; Bekker, J.M.; Fineman, J.R.; Black, S.M. Role for endothelin-1-induced superoxide and peroxynitrite production in rebound pulmonary hypertension associated with inhaled nitric oxide therapy. Circ. Res. 2001, 89, 357-364. [CrossRef] [PubMed]

130. Miller, O.; Tang, S.; Keech, A.; Celermajer, D. Rebound pulmonary hypertension on withdrawal from inhaled nitric oxide. Lancet 1995, 346, 51-52. [CrossRef]

131. Atz, A.M.; Adatia, I.; Wessel, D.L. Rebound Pulmonary Hypertension After Inhalation of Nitric Oxide. Ann. Thorac. Surg. 1996, 62, 1759-1764. [CrossRef]

132. Kostić, D.A.; Dimitrijević, D.S.; Stojanović, G.S.; Palić, I.R.; Đorđević, A.; Ickovski, J. Xanthine Oxidase: Isolation, Assays of Activity, and Inhibition. J. Chem. 2015, 2015, 294858. [CrossRef]

133. Cantu-Medellin, N.; Kelley, E.E. Xanthine oxidoreductase-catalyzed reactive species generation: A process in critical need of reevaluation. Redox Biol. 2013, 1, 353-358. [CrossRef] [PubMed]

134. Kuwabara, Y.; Nishino, T.; Okamoto, K.; Matsumura, T.; Eger, B.T.; Pai, E.F.; Nishino, T. Unique amino acids cluster for switching from the dehydrogenase to oxidase form of xanthine oxidoreductase. Proc. Natl. Acad. Sci. USA 2003, 100, 8170-8175. [CrossRef]

135. Battelli, M.G.; Polito, L.; Bortolotti, M.; Bolognesi, A. Xanthine Oxidoreductase in Drug Metabolism: Beyond a Role as a Detoxifying Enzyme. Curr. Med. Chem. 2016, 23, 4027-4036. [CrossRef] [PubMed]

136. Chen, C.; Lü, J.-M.; Yao, Q. Hyperuricemia-Related Diseases and Xanthine Oxidoreductase (XOR) Inhibitors: An Overview. Med. Sci. Monit. 2016, 22, 2501-2512. [CrossRef]

137. Kelley, E.E.; Khoo, N.K.; Hundley, N.J.; Malik, U.Z.; Freeman, B.A.; Tarpey, M.M. Hydrogen peroxide is the major oxidant product of xanthine oxidase. Free Radic. Biol. Med. 2010, 48, 493-498. [CrossRef]

138. Terada, L.S.; Guidot, D.M.; Leff, J.A.; Willingham, I.R.; Hanley, M.E.; Piermattei, D.; Repine, J.E. Hypoxia injures endothelial cells by increasing endogenous xanthine oxidase activity. Proc. Natl. Acad. Sci. USA 1992, 89, 3362-3366. [CrossRef]

139. Cheong, P.L.S. Effects of Xanthine Oxidase Inhibitors in Pulmonary Hypertension Associated with Chronic Lung Disease. Ph.D. Thesis, University of Dundee, Dundee, UK, 2019.

140. Thorpe, L.W.; Westlund, K.N.; Kochersperger, L.M.; Abell, C.W.; Denney, R.M. Immunocytochemical localization of monoamine oxidases A and B in human peripheral tissues and brain. J. Histochem. Cytochem. 1987, 35, 23-32. [CrossRef]

141. Shih, J.C.; Chen, K.; Ridd, M.J. Monoamine Oxidase: From Genes to Behavior. Annu. Rev. Neurosci. 1999, 22, 197-217. [CrossRef] [PubMed]

142. Fowler, C.J.; Mantle, T.J.; Tipton, K.F. The nature of the inhibition of rat liver monoamine oxidase types A and B by the acetylenic inhibitors clorgyline, 1-deprenyl and pargyline. Biochem. Pharmacol. 1982, 31, 3555-3561. [CrossRef] 
143. Green, A.R.; Youdim, M.B. Effects of Monoamine Oxidase Inhibition by Clorgyline, Deprenil or Tranylcypromine on 5-Hydroxytryptamine Concentrations in Rat Brain and Hyperactivity Following Subsequent Tryptophan Administration. Br. J. Pharmacol. 1975, 55, 415-422. [CrossRef] [PubMed]

144. Fowler, C.J.; Benedetti, M.S. The Metabolism of Dopamine by Both Forms of Monoamine Oxidase in the Rat Brain and Its Inhibition by Cimoxatone. J. Neurochem. 1983, 40, 1534-1541. [CrossRef] [PubMed]

145. O'Carroll, A.-M.; Fowler, C.J.; Phillips, J.P.; Tobbia, I.; Tipton, K.F. The deamination of dopamine by human brain monoamine oxidase. Specificity for the two enzyme forms in seven brain regions. Naunyn Schmiedeberg's Arch. Pharmacol. 1983, 322, 198-202. [CrossRef] [PubMed]

146. Tsugeno, Y.; Ito, A. A Key Amino Acid Responsible for Substrate Selectivity of Monoamine Oxidase A and B. J. Biol. Chem. 1997, 272, 14033-14036. [CrossRef]

147. Gaweska, H.; Fitzpatrick, P.F. Structures and mechanism of the monoamine oxidase family. Biomol. Concepts 2011, 2, 365-377. [CrossRef] [PubMed]

148. Peña-Silva, R.A.; Miller, J.D.; Chu, Y.; Heistad, D.D. Serotonin produces monoamine oxidase-dependent oxidative stress in human heart valves. Am. J. Physiol. Heart Circ. Physiol. 2009, 297, H1354-H1360. [CrossRef]

149. Zang, L.Y.; Misra, H.P. Generation of reactive oxygen species during the monoamine oxidase-catalyzed oxidation of the neurotoxicant, 1-methyl-4-phenyl-1,2,3,6-tetrahydropyridine. J. Biol. Chem. 1993, 268, 16504-16512.

150. Sandri, G.; Panfili, E.; Ernster, L. Hydrogen peroxide production by monoamine oxidase in isolated rat-brain mitochondria: Its effect on glutathione levels and Ca2+ efflux. Biochim. Biophys. Acta 1990, 1035, 300-305. [CrossRef]

151. Maurel-Ribes, A.; Hernandez, C.; Kunduzova, O.; Bompart, G.; Cambon, C.; Parini, A.; Francès, B. Age-dependent increase in hydrogen peroxide production by cardiac monoamine oxidase A in rats. Am. J. Physiol. Heart Circ. Physiol. 2003, 284, H1460-H1467. [CrossRef]

152. Kunduzova, O.R.; Bianchi, P.; Parini, A.; Cambon, C. Hydrogen peroxide production by monoamine oxidase during ischemia/reperfusion. Eur. J. Pharmacol. 2002, 448, 225-230. [CrossRef]

153. Simonson, S.G.; Zhang, J.; Canada, A.T.; Su, Y.-F.; Benveniste, H.; Piantadosi, C.A. Hydrogen Peroxide Production by Monoamine Oxidase during Ischemia-Reperfusion in the Rat Brain. J. Cereb. Blood Flow Metab. 1993, 13, 125-134. [CrossRef] [PubMed]

154. Wang, J.; Edmondson, D.E. Topological probes of monoamine oxidases A and B in rat liver mitochondria: Inhibition by TEMPO-substituted pargyline analogues and inactivation by proteolysis. Biochemistry 2011, 50, 2499-2505. [CrossRef]

155. Mitoma, J.-Y.; Ito, A. Mitochondrial Targeting Signal of Rat Liver Monoamine Oxidase B Is Located at Its Carboxy Terminus. J. Biochem. 1992, 111, 20-24. [CrossRef]

156. Son, S.-Y.; Ma, J.; Kondou, Y.; Yoshimura, M.; Yamashita, E.; Tsukihara, T. Structure of human monoamine oxidase A at 2.2-A resolution: The control of opening the entry for substrates/inhibitors. Proc. Natl. Acad. Sci. USA 2008, 105, 5739-5744. [CrossRef] [PubMed]

157. Sorato, E.; Menazza, S.; Zulian, A.; Sabatelli, P.; Gualandi, F.; Merlini, L.; Bonaldo, P.; Canton, M.; Bernardi, P.; Di Lisa, F. Monoamine oxidase inhibition prevents mitochondrial dysfunction and apoptosis in myoblasts from patients with collagen VI myopathies. Free Radic. Biol. Med. 2014, 75, 40-47. [CrossRef] [PubMed]

158. Kaludercic, N.; Carpi, A.; Nagayama, T.; Sivakumaran, V.; Zhu, G.; Lai, E.W.; Bedja, D.; De Mario, A.; Chen, K.; Gabrielson, K.L.; et al. Monoamine Oxidase B Prompts Mitochondrial and Cardiac Dysfunction in Pressure Overloaded Hearts. Antioxid. Redox Signal 2014, 20, 267-280. [CrossRef]

159. Antonucci, S.; Di Sante, M.; Tonolo, F.; Pontarollo, L.; Scalcon, V.; Alanova, P.; Menabo', R.; Carpi, A.; Bindoli, A.; Rigobello, M.P.; et al. The Determining Role of Mitochondrial Reactive Oxygen Species Generation and Monoamine Oxidase Activity in Doxorubicin-Induced Cardiotoxicity. Antioxid. Redox Signal. 2020. [CrossRef]

160. Jana, S.; Sinha, M.; Chanda, D.; Roy, T.; Banerjee, K.; Munshi, S.; Patro, B.S.; Chakrabarti, S. Mitochondrial dysfunction mediated by quinone oxidation products of dopamine: Implications in dopamine cytotoxicity and pathogenesis of Parkinson's disease. Biochim. Biophys. Acta 2011, 1812, 663-673. [CrossRef] 
161. Sun, X.; Peters, E.; Schalij, I.; Andersen, S.; Bos, D.D.S.G.; Noordegraaf, A.V.; De Man, F.; Van Der Laarse, W.; Bogaard, H. Inhibition of Monoamine Oxidase-A Reduces Pulmonary Vascular Remodeling in Experimentally Induced Pulmonary Arterial Hypertension, in B108. In Under Pressure: The Role of Cellular Stress in Pulmonary Vascular Remodeling; American Thoracic Society: New York, NY, USA, 2019; p. A4205. [CrossRef]

162. Sun, X.; Peters, E.; Schalij, I.; Andersen, S.; Bos, D.D.S.G.; Vonk-Noordegraaf, A.; De Man, F.; Van Der Laarse, W.; Bogaard, H. The effect of Monoamine oxidase A inhibition on experimentally induced pulmonary arterial hypertension. Eur. Respir. J. 2018, 52 (Suppl. S62), PA3072. [CrossRef]

163. Archer, S.L.; Marsboom, G.; Kim, G.H.; Zhang, H.J.; Toth, P.T.; Svensson, E.C.; Dyck, J.R.; Gomberg-Maitland, M.; Thébaud, B.; Husain, A.N.; et al. Epigenetic attenuation of mitochondrial superoxide dismutase 2 in pulmonary arterial hypertension: A basis for excessive cell proliferation and a new therapeutic target. Circulation 2010, 121, 2661-2671. [CrossRef]

164. Bonnet, S.; Michelakis, E.D.; Porter, C.J.; Andrade-Navarro, M.A.; Thébaud, B.; Bonnet, S.; Haromy, A.; Harry, G.; Moudgil, R.; McMurtry, M.S.; et al. An abnormal mitochondrial-hypoxia inducible factor-1alpha-Kv channel pathway disrupts oxygen sensing and triggers pulmonary arterial hypertension in fawn hooded rats: Similarities to human pulmonary arterial hypertension. Circulation 2006, 113, 2630-2641. [CrossRef] [PubMed]

165. Dennis, K.E.; Aschner, J.L.; Milatović, D.; Schmidt, J.W.; Aschner, M.; Kaplowitz, M.R.; Zhang, Y.; Fike, C.D. NADPH oxidases and reactive oxygen species at different stages of chronic hypoxia-induced pulmonary hypertension in newborn piglets. Am. J. Physiol. Lung Cell. Mol. Physiol. 2009, 297, L596-L607. [CrossRef] [PubMed]

166. Ramiro-Diaz, J.M.; Nitta, C.H.; Maston, L.D.; Codianni, S.; Giermakowska, W.; Resta, T.C.; Bosc, L.V.G. NFAT is required for spontaneous pulmonary hypertension in superoxide dismutase 1 knockout mice. Am. J. Physiol. Lung Cell. Mol. Physiol. 2013, 304, L613-L625. [CrossRef]

167. Brennan, L.A.; Steinhorn, R.; Wedgwood, S.; Mata-Greenwood, E.; Roark, E.A.; Russell, J.A.; Black, S.M. Increased Superoxide Generation Is Associated With Pulmonary Hypertension in Fetal Lambs. Circ. Res. 2003, 92, 683-691. [CrossRef] [PubMed]

168. Bowers, R.; Cool, C.; Murphy, R.C.; Tuder, R.M.; Hopken, M.W.; Flores, S.C.; Voelkel, N.F. Oxidative Stress in Severe Pulmonary Hypertension. Am. J. Respir. Crit. Care Med. 2004, 169, 764-769. [CrossRef] [PubMed]

169. Alhawaj, R.; Patel, D.; Kelly, M.R.; Sun, N.; Wolin, M.S. Heme biosynthesis modulation via $\delta$-aminolevulinic acid administration attenuates chronic hypoxia-induced pulmonary hypertension. Am. J. Physiol. Lung Cell. Mol. Physiol. 2015, 308, L719-L728. [CrossRef]

170. Afolayan, A.J.; Eis, A.; Teng, R.-J.; Bakhutashvili, I.; Kaul, S.; Davis, J.M.; Konduri, G.G. Decreases in manganese superoxide dismutase expression and activity contribute to oxidative stress in persistent pulmonary hypertension of the newborn. Am. J. Physiol. Lung Cell. Mol. Physiol. 2012, 303, L870-L879. [CrossRef] [PubMed]

171. Zhang, Y.; Xu, J. miR-140-5p regulates hypoxia-mediated human pulmonary artery smooth muscle cell proliferation, apoptosis and differentiation by targeting Dnmt1 and promoting SOD2 expression. Biochem. Biophys. Res. Commun. 2016, 473, 342-348. [CrossRef]

172. Tseng, V.; Ni, K.; Allawzi, A.; Prohaska, C.; Hernandez-Lagunas, L.; Elajaili, H.; Cali, V.; Midura, R.; Hascall, V.; Triggs-Raine, B.; et al. Extracellular Superoxide Dismutase Regulates Early Vascular Hyaluronan Remodeling in Hypoxic Pulmonary Hypertension. Sci. Rep. 2020, 10, 280. [CrossRef]

173. Hartney, T.; Birari, R.; Venkataraman, S.; Villegas, L.; Martinez, M.; Black, S.M.; Stenmark, K.R.; Nozik-Gryck, E. Xanthine oxidase-derived ROS upregulate Egr-1 via ERK1/2 in PA smooth muscle cells; model to test impact of extracellular ROS in chronic hypoxia. PLoS ONE 2011, 6, e27531. [CrossRef] [PubMed]

174. Nozik-Grayck, E.; Woods, C.; Taylor, J.M.; Benninger, R.K.P.; Johnson, R.D.; Villegas, L.R.; Stenmark, K.R.; Harrison, D.G.; Majka, S.M.; Irwin, D.; et al. Selective depletion of vascular EC-SOD augments chronic hypoxic pulmonary hypertension. Am. J. Physiol. Lung Cell. Mol. Physiol. 2014, 307, L868-L876. [CrossRef] [PubMed]

175. Xu, D.; Guo, H.; Xu, X.; Chen, Y.; Fassett, J.; Hu, X.; Xu, Y.; Tang, Q.; Hu, D.; Somani, A.; et al. Exacerbated pulmonary arterial hypertension and right ventricular hypertrophy in animals with loss of function of extracellular superoxide dismutase. Hypertension 2011, 58, 303-309. [CrossRef] [PubMed] 
176. Ducret, T.; El Arrouchi, J.; Courtois, A.; Quignard, J.-F.; Marthan, R.; Savineau, J.-P. Stretch-activated channels in pulmonary arterial smooth muscle cells from normoxic and chronically hypoxic rats. Cell Calcium 2010, 48, 251-259. [CrossRef]

177. Wang, J.; Weigand, L.; Lu, W.; Sylvester, J.; Semenza, G.L.; Shimoda, L.A. Hypoxia Inducible Factor 1 Mediates Hypoxia-Induced TRPC Expression and Elevated Intracellular Ca 2+ in Pulmonary Arterial Smooth Muscle Cells. Circ. Res. 2006, 98, 1528-1537. [CrossRef]

178. Lin, M.; Leung, G.P.; Zhang, W.-M.; Yang, X.-R.; Yip, K.-P.; Tse, C.-M.; Sham, J.S. Chronic hypoxia-induced upregulation of store-operated and receptor-operated Ca2+ channels in pulmonary arterial smooth muscle cells: A novel mechanism of hypoxic pulmonary hypertension. Circ. Res. 2004, 95, 496-505. [CrossRef]

179. Chevalier, M.; Gilbert, G.; Roux, E.; Lory, P.; Marthan, R.; Savineau, J.-P.; Quignard, J.-F. T-type calcium channels are involved in hypoxic pulmonary hypertension. Cardiovasc. Res. 2014, 103, 597-606. [CrossRef]

180. Shimoda, L.A.; Sham, J.S.K.; Shimoda, T.H.; Sylvester, J.T. L-type Ca(2+) channels, resting [Ca(2+)](i), and ET-1-induced responses in chronically hypoxic pulmonary myocytes. Am. J. Physiol. Lung Cell. Mol. Physiol. 2000, 279, L884-L894. [CrossRef]

181. Nagaoka, T.; Morio, Y.; Casanova, N.; Bauer, N.; Gebb, S.; McMurtry, I.; Oka, M. Rho/Rho kinase signaling mediates increased basal pulmonary vascular tone in chronically hypoxic rats. Am. J. Physiol. Lung Cell. Mol. Physiol. 2004, 287, L665-L672. [CrossRef]

182. Weigand, L.; Sylvester, J.T.; Shimoda, L.A. Mechanisms of endothelin-1-induced contraction in pulmonary arteries from chronically hypoxic rats. Am. J. Physiol. Lung Cell. Mol. Physiol. 2006, 290, L284-L290. [CrossRef] [PubMed]

183. Catterall, W.A. Voltage-gated calcium channels. Cold Spring Harb. Perspect. Biol. 2011, 3, a003947. [CrossRef] [PubMed]

184. Firth, A.L.; Remillard, C.V.; Platoshyn, O.; Fantozzi, I.; Ko, E.A.; Yuan, J.X.-J. Functional Ion Channels in Human Pulmonary Artery Smooth Muscle Cells: Voltage-Dependent Cation Channels. Pulm. Circ. 2011, 1, 48-71. [CrossRef]

185. Makino, A.; Firth, A.L.; Yuan, J.X.-J. Endothelial and smooth muscle cell ion channels in pulmonary vasoconstriction and vascular remodeling. Compr. Physiol. 2011, 1, 1555-1602. [CrossRef] [PubMed]

186. Shimoda, L.A.; Sylvester, J.T.; Sham, J.S.K. Chronic hypoxia alters effects of endothelin and angiotensin on K+ currents in pulmonary arterial myocytes. Am. J. Physiol. 1999, 277, L431-L439. [CrossRef]

187. Reeve, H.L.; Michelakis, E.; Nelson, D.P.; Weir, E.K.; Archer, S.L. Alterations in a redox oxygen sensing mechanism in chronic hypoxia. J. Appl. Physiol. 2001, 90, 2249-2256. [CrossRef] [PubMed]

188. Yuan, J.X.-J.; Aldinger, A.M.; Juhaszova, M.; Wang, J.; Conte, J.V.; Gaine, S.P.; Orens, J.B.; Rubin, L.J. Dysfunctional Voltage-Gated K + Channels in Pulmonary Artery Smooth Muscle Cells of Patients With Primary Pulmonary Hypertension. Circulation 1998, 98, 1400-1406. [CrossRef]

189. Lai, N.; Lu, W.; Wang, J. Ca2+ and ion channels in hypoxia-mediated pulmonary hypertension. Int. J. Clin. Exp. Pathol. 2015, 8, 1081-1092.

190. Liou, J.; Kim, M.L.; Heo, W.D.; Jones, J.T.; Myers, J.W.; Ferrell, J.E.; Meyer, T. STIM Is a Ca2+ Sensor Essential for Ca2+-Store-Depletion-Triggered Ca2+ Influx. Curr. Biol. 2005, 15, 1235-1241. [CrossRef]

191. Hewavitharana, T.; Deng, X.; Soboloff, J.; Gill, D.L. Role of STIM and Orai proteins in the store-operated calcium signaling pathway. Cell Calcium 2007, 42, 173-182. [CrossRef]

192. Garcia, S.M.; Herbert, L.M.; Walker, B.R.; Resta, T.C.; Jernigan, N.L. Coupling of store-operated calcium entry to vasoconstriction is acid-sensing ion channel 1a dependent in pulmonary but not mesenteric arteries. PLoS ONE 2020, 15, e0236288. [CrossRef]

193. Salido, G.M.; Jardin, I.; Rosado, J.A. The TRPC ion channels: Association with Orai1 and STIM1 proteins and participation in capacitative and non-capacitative calcium entry. Adv. Exp. Med. Biol. 2011, 704, 413-433. [CrossRef] [PubMed]

194. Snow, J.B.; Kanagy, N.L.; Walker, B.R.; Resta, T.C. Rat Strain Differences in Pulmonary Artery Smooth Muscle Ca2+Entry Following Chronic Hypoxia. Microcirculation 2009, 16, 603-614. [CrossRef] [PubMed]

195. Hirenallur-S, D.K.; Haworth, S.T.; Leming, J.T.; Chang, J.; Hernández, G.; Gordon, J.B.; Rusch, N.J. Upregulation of vascular calcium channels in neonatal piglets with hypoxia-induced pulmonary hypertension. Am. J. Physiol. Lung Cell. Mol. Physiol. 2008, 295, L915-L924. [CrossRef] [PubMed] 
196. Wan, J.; Yamamura, A.; Zimnicka, A.M.; Voiriot, G.; Smith, K.A.; Tang, H.; Ayon, R.J.; Choudhury, M.S.R.; Ko, E.A.; Wang, J.; et al. Chronic hypoxia selectively enhances L- and T-type voltage-dependent Ca2+ channel activity in pulmonary artery by upregulating Cav1.2 and Cav3.2. Am. J. Physiol. Lung Cell. Mol. Physiol. 2013, 305, L154-L164. [CrossRef] [PubMed]

197. Oka, M.; Morris, K.G.; McMurtry, I.F. NIP-121 is more effective than nifedipine in acutely reversing chronic pulmonary hypertension. J. Appl. Physiol. 1993, 75, 1075-1080. [CrossRef] [PubMed]

198. Johnson, D.C.; Joshi, R.C.; Mehta, R.; Cunnington, A.R. Acute and long term effect of nifedipine on pulmonary hypertension secondary to chronic obstructive airways disease. Eur. J. Respir. Dis. Suppl. 1986, 146, 495-502.

199. Brown, S.E.; Linden, G.S.; King, R.R.; Blair, G.P.; Stansbury, D.W.; Light, R.W. Effects of verapamil on pulmonary haemodynamics during hypoxaemia, at rest, and during exercise in patients with chronic obstructive pulmonary disease. Thorax 1983, 38, 840-844. [CrossRef]

200. Chen, T.-X.; Xu, X.-Y.; Zhao, Z.; Zhao, F.-Y.; Gao, Y.-M.; Yan, X.-H.; Wan, Y. Hydrogen peroxide is a critical regulator of the hypoxia-induced alterations of store-operated $\mathrm{Ca} 2+$ entry into rat pulmonary arterial smooth muscle cells. Am. J. Physiol. Lung Cell. Mol. Physiol. 2017, 312, L477-L487. [CrossRef]

201. Malczyk, M.; Veith, C.; Fuchs, B.; Hofmann, K.; Storch, U.; Schermuly, R.T.; Witzenrath, M.; Ahlbrecht, K.; Fecher-Trost, C.; Flockerzi, V.; et al. Classical Transient Receptor Potential Channel 1 in Hypoxia-induced Pulmonary Hypertension. Am. J. Respir. Crit. Care Med. 2013, 188, 1451-1459. [CrossRef]

202. Xia, Y.; Yang, X.R.; Fu, Z.; Paudel, O.; Abramowitz, J.; Birnbaumer, L.; Sham, J.S. Classical transient receptor potential 1 and 6 contribute to hypoxic pulmonary hypertension through differential regulation of pulmonary vascular functions. Hypertension 2014, 63, 173-180. [CrossRef]

203. Smith, K.A.; Voiriot, G.; Tang, H.; Fraidenburg, D.R.; Song, S.; Yamamura, H.; Yamamura, A.; Guo, Q.; Wan, J.; Pohl, N.M.; et al. Notch Activation of Ca2+Signaling in the Development of Hypoxic Pulmonary Vasoconstriction and Pulmonary Hypertension. Am. J. Respir. Cell Mol. Biol. 2015, 53, 355-367. [CrossRef] [PubMed]

204. Yang, X.-R.; Lin, A.H.Y.; Hughes, J.M.; Flavahan, N.A.; Cao, Y.-N.; Liedtke, W.; Sham, J.S.K. Upregulation of osmo-mechanosensitive TRPV4 channel facilitates chronic hypoxia-induced myogenic tone and pulmonary hypertension. Am. J. Physiol. Lung Cell. Mol. Physiol. 2012, 302, L555-L568. [CrossRef] [PubMed]

205. Dahan, D.; Ducret, T.; Quignard, J.-F.; Marthan, R.; Savineau, J.-P.; Estève, E. Implication of the ryanodine receptor in TRPV4-induced calcium response in pulmonary arterial smooth muscle cells from normoxic and chronically hypoxic rats. Am. J. Physiol. Lung Cell. Mol. Physiol. 2012, 303, L824-L833. [CrossRef]

206. Xia, Y.; Fu, Z.; Hu, J.; Huang, C.; Paudel, O.; Cai, S.; Liedtke, W.; Sham, J.S.K. TRPV4 channel contributes to serotonin-induced pulmonary vasoconstriction and the enhanced vascular reactivity in chronic hypoxic pulmonary hypertension. Am. J. Physiol. Cell Physiol. 2013, 305, C704-C715. [CrossRef]

207. Nitta, C.H.; Osmond, D.A.; Herbert, L.M.; Beasley, B.F.; Resta, T.C.; Walker, B.R.; Jernigan, N.L. Role of ASIC1 in the development of chronic hypoxia-induced pulmonary hypertension. Am. J. Physiol. Heart Circ. Physiol. 2014, 306, H41-H52. [CrossRef]

208. He, X.; Song, S.; Ayon, R.J.; Balisterieri, A.; Black, S.M.; Makino, A.; Gil Wier, W.; Zang, W.-J.; Yuan, J.X.-J. Hypoxia selectively upregulates cation channels and increases cytosolic $\left[\mathrm{Ca}^{2+}\right]$ in pulmonary, but not coronary, arterial smooth muscle cells. Am. J. Physiol. Cell Physiol. 2018, 314, C504-C517. [CrossRef]

209. Song, M.Y.; Makino, A.; Yuan, J.X.-J. STIM2 Contributes to Enhanced Store-Operated Ca ${ }^{2+}$ Entry in Pulmonary Artery Smooth Muscle Cells from Patients with Idiopathic Pulmonary Arterial Hypertension. Pulm. Circ. 2011, 1, 84-94. [CrossRef] [PubMed]

210. Campbell, D.L.; Stamler, J.S.; Strauss, H.C. Redox modulation of L-type calcium channels in ferret ventricular myocytes. Dual mechanism regulation by nitric oxide and S-nitrosothiols. J. Gen. Physiol. 1996, 108, 277-293. [CrossRef] [PubMed]

211. Hu, H.; Chiamvimonvat, N.; Yamagishi, T.; Marban, E. Direct inhibition of expressed cardiac L-type Ca2+ channels by S-nitrosothiol nitric oxide donors. Circ. Res. 1997, 81, 742-752. [CrossRef]

212. Viola, H.M.; Arthur, P.G.; Hool, L.C. Transient Exposure to Hydrogen Peroxide Causes an Increase in Mitochondria-Derived Superoxide As a Result of Sustained Alteration in L-Type $\mathrm{Ca}^{2+}$ Channel Function in the Absence of Apoptosis in Ventricular Myocytes. Circ. Res. 2007, 100, 1036-1044. [CrossRef] 
213. Akaishi, T.; Nakazawa, K.; Sato, K.; Saito, H.; Ohno, Y.; Ito, Y. Hydrogen peroxide modulates whole cell Ca2+ currents through L-type channels in cultured rat dentate granule cells. Neurosci. Lett. 2004, 356, $25-28$. [CrossRef] [PubMed]

214. Yang, L.; Xu, J.; Minobe, E.; Yu, L.; Feng, R.; Kameyama, A.; Yazawa, K.; Kameyama, M. Mechanisms underlying the modulation of L-type $\mathrm{Ca} 2+$ channel by hydrogen peroxide in guinea pig ventricular myocytes. J. Physiol. Sci. 2013, 63, 419-426. [CrossRef]

215. Luke, T.; Maylor, J.; Undem, C.; Sylvester, J.T.; Shimoda, L.A. Kinase-dependent activation of voltage-gated Ca2+ channels by ET-1 in pulmonary arterial myocytes during chronic hypoxia. Am. J. Physiol. Lung Cell. Mol. Physiol. 2012, 302, L1128-L1139. [CrossRef] [PubMed]

216. Cosentino-Gomes, D.; Rocco-Machado, N.; Meyer-Fernandes, J.R. Cell Signaling through Protein Kinase C Oxidation and Activation. Int. J. Mol. Sci. 2012, 13, 10697-10721. [CrossRef] [PubMed]

217. Wu, W.; Platoshyn, O.; Firth, A.L.; Yuan, J.X.-J. Hypoxia divergently regulates production of reactive oxygen species in human pulmonary and coronary artery smooth muscle cells. Am. J. Physiol. Lung Cell. Mol. Physiol. 2007, 293, L952-L959. [CrossRef]

218. Wedgwood, S.; Black, S.M. Endothelin-1 decreases endothelial NOS expression and activity through ETA receptor-mediated generation of hydrogen peroxide. Am. J. Physiol. Lung Cell. Mol. Physiol. 2005, 288, L480-L487. [CrossRef]

219. Zeng, Q.; Zhou, Q.; Yao, F.; O’Rourke, S.T.; Sun, C. Endothelin-1 Regulates Cardiac L-Type Calcium Channels via NAD(P)H Oxidase-Derived Superoxide. J. Pharmacol. Exp. Ther. 2008, 326, 732-738. [CrossRef]

220. Weissmann, N.; Dietrich, A.; Fuchs, B.; Kalwa, H.; Ay, M.; Dumitrascu, R.; Olschewski, A.; Storch, U.; Schnitzler, M.M.Y.; Ghofrani, H.-A.; et al. Classical transient receptor potential channel 6 (TRPC6) is essential for hypoxic pulmonary vasoconstriction and alveolar gas exchange. Proc. Natl. Acad. Sci. USA 2006, 103, 19093-19098. [CrossRef]

221. Aires, V.; Hichami, A.; Boulay, G.; Khan, N.A. Activation of TRPC6 calcium channels by diacylglycerol (DAG)-containing arachidonic acid: A comparative study with DAG-containing docosahexaenoic acid. Biochimie 2007, 89, 926-937. [CrossRef]

222. Weissmann, N.; Sydykov, A.; Kalwa, H.; Storch, U.; Fuchs, B.; Schnitzler, M.M.Y.; Brandes, R.P.; Grimminger, F.; Meissner, M.; Freichel, M.; et al. Activation of TRPC6 channels is essential for lung ischaemia-reperfusion induced oedema in mice. Nat. Commun. 2012, 3, 649. [CrossRef]

223. Inoue, R.; Jensen, L.J.; Jian, Z.; Shi, J.; Hai, L.; Lurie, A.I.; Henriksen, F.H.; Salomonsson, M.; Morita, H.; Kawarabayashi, Y.; et al. Synergistic activation of vascular TRPC6 channel by receptor and mechanical stimulation via phospholipase C/diacylglycerol and phospholipase A2/omega-hydroxylase/20HETE pathways. Circ. Res. 2009, 104, 1399-1409. [CrossRef] [PubMed]

224. Ding, Y.; Winters, A.; Ding, M.; Graham, S.; Akopova, I.; Muallem, S.; Wang, Y.; Hong, J.H.; Gryczynski, Z.; Yang, S.-H.; et al. Reactive Oxygen Species-mediated TRPC6 Protein Activation in Vascular Myocytes, a Mechanism for Vasoconstrictor-regulated Vascular Tone. J. Biol. Chem. 2011, 286, 31799-31809. [CrossRef] [PubMed]

225. Marziano, C.; Hong, K.; Cope, E.L.; Kotlikoff, M.I.; Isakson, B.E.; Sonkusare, S.K. Nitric Oxide-Dependent Feedback Loop Regulates Transient Receptor Potential Vanilloid 4 (TRPV4) Channel Cooperativity and Endothelial Function in Small Pulmonary Arteries. J. Am. Heart Assoc. 2017, 6, e007157. [CrossRef]

226. Sukumaran, S.V.; Singh, T.U.; Parida, S.; Reddy, C.N.; Thangamalai, R.; Kandasamy, K.; Singh, V.; Mishra, S.K. TRPV4 channel activation leads to endothelium-dependent relaxation mediated by nitric oxide and endothelium-derived hyperpolarizing factor in rat pulmonary artery. Pharmacol. Res. 2013, 78, 18-27. [CrossRef]

227. Ottolini, M.; Daneva, Z.; Chen, Y.L.; Cope, E.L.; Kasetti, R.B.; Zode, G.S.; Sonkusare, S.K. Mechanisms underlying selective coupling of endothelial $\mathrm{Ca}(2+)$ signals with eNOS vs. IK/SK channels in systemic and pulmonary arteries. J. Physiol. 2020, 598, 3577-3596. [CrossRef] [PubMed]

228. Cussac, L.-A.; Cardouat, G.; Pillai, N.T.; Campagnac, M.; Robillard, P.; Montillaud, A.; Guibert, C.; Gailly, P.; Marthan, R.; Quignard, J.-F.; et al. TRPV4 channel mediates adventitial fibroblast activation and adventitial remodeling in pulmonary hypertension. Am. J. Physiol. Lung Cell. Mol. Physiol. 2020, 318, L135-L146. [CrossRef] [PubMed] 
229. Pankey, E.A.; Zsombok, A.; Lasker, G.F.; Kadowitz, P.J. Analysis of responses to the TRPV4 agonist GSK1016790A in the pulmonary vascular bed of the intact-chest rat. Am. J. Physiol. Heart Circ. Physiol. 2014, 306, 33-40. [CrossRef] [PubMed]

230. Suresh, K.; Servinsky, L.; Reyes, J.; Baksh, S.; Undem, C.; Caterina, M.; Pearse, D.B.; Shimoda, L.A. Hydrogen peroxide-induced calcium influx in lung microvascular endothelial cells involves TRPV4. Am. J. Physiol. Lung Cell. Mol. Physiol. 2015, 309, L1467-L1477. [CrossRef]

231. Suresh, K.; Servinsky, L.; Reyes, J.; Undem, C.; Zaldumbide, J.; Rentsendorj, O.; Modekurty, S.; Dodd-O, J.M.; Scott, A.L.; Pearse, D.B.; et al. CD36 mediates H2O2-induced calcium influx in lung microvascular endothelial cells. Am. J. Physiol. Lung Cell. Mol. Physiol. 2017, 312, L143-L153. [CrossRef]

232. Cao, S.; Anishkin, A.; Zinkevich, N.S.; Nishijima, Y.; Korishettar, A.; Wang, Z.; Fang, J.; Wilcox, D.A.; Zhang, D.X. Transient receptor potential vanilloid 4 (TRPV4) activation by arachidonic acid requires protein kinase A-mediated phosphorylation. J. Biol. Chem. 2018, 293, 5307-5322. [CrossRef]

233. Suresh, K.; Servinsky, L.; Jiang, H.; Bigham, Z.; Zaldumbide, J.; Huetsch, J.C.; Kliment, C.; Acoba, M.G.; Kirsch, B.J.; Claypool, S.M.; et al. Regulation of mitochondrial fragmentation in microvascular endothelial cells isolated from the SU5416/hypoxia model of pulmonary arterial hypertension. Am. J. Physiol. Lung. Cell Mol. Physiol. 2019, 317, L639-L652. [CrossRef] [PubMed]

234. Jernigan, N.L. Smooth muscle acid-sensing ion channel 1: Pathophysiological implication in hypoxic pulmonary hypertension. Exp. Physiol. 2015, 100, 111-120. [CrossRef] [PubMed]

235. Sherwood, T.W.; Frey, E.N.; Askwith, C.C. Structure and activity of the acid-sensing ion channels. Am. J. Physiol. Cell Physiol. 2012, 303, C699-C710. [CrossRef] [PubMed]

236. Mukhopadhyay, M.; Bera, A.K. Modulation of acid-sensing ion channels by hydrogen sulfide. Biochem. Biophys. Res. Commun. 2020, 527, 71-75. [CrossRef] [PubMed]

237. Andrey, F.; Tsintsadze, T.; Volkova, T.; Lozovaya, N.; Krishtal, O. Acid sensing ionic channels: Modulation by redox reagents. Biochim. Biophys. Acta 2005, 1745, 1-6. [CrossRef] [PubMed]

238. Cho, J.-H.; Askwith, C.C. Potentiation of acid-sensing ion channels by sulfhydryl compounds. Am. J. Physiol. Cell Physiol. 2007, 292, C2161-C2174. [CrossRef] [PubMed]

239. Chu, X.-P.; Close, N.; Saugstad, J.A.; Xiong, Z.-G. ASIC1a-specific modulation of acid-sensing ion channels in mouse cortical neurons by redox reagents. J. Neurosci. 2006, 26, 5329-5339. [CrossRef]

240. Mungai, P.T.; Waypa, G.B.; Jairaman, A.; Prakriya, M.; Dokic, D.; Ball, M.K.; Schumacker, P.T. Hypoxia Triggers AMPK Activation through Reactive Oxygen Species-Mediated Activation of Calcium Release-Activated Calcium Channels. Mol. Cell. Biol. 2011, 31, 3531-3545. [CrossRef]

241. Dyachenko, V.; Rueckschloss, U.; Isenberg, G. Modulation of cardiac mechanosensitive ion channels involves superoxide, nitric oxide and peroxynitrite. Cell Calcium 2009, 45, 55-64. [CrossRef]

242. Burg, E.D.; Remillard, C.V.; Yuan, J.X.-J. Potassium channels in the regulation of pulmonary artery smooth muscle cell proliferation and apoptosis: Pharmacotherapeutic implications. Br. J. Pharmacol. 2008, 153 (Suppl. S1), S99-S111. [CrossRef]

243. Weise-Cross, L.; Resta, T.C.; Jernigan, N.L. Redox Regulation of Ion Channels and Receptors in Pulmonary Hypertension. Antioxid. Redox Signal. 2019, 31, 898-915. [CrossRef] [PubMed]

244. Ayon, R.J.; Tang, H.; Fernandez, R.A.; Makino, A.; Yuan, J.X.-J. Smooth Muscle Cell Ion Channels in Pulmonary Arterial Hypertension: Pathogenic Role in Pulmonary Vasoconstriction and Vascular Remodeling. In Vascular Ion Channels in Physiology and Disease; Levitan, P.I., Dopico, M.D.P.A.M., Eds.; Springer International Publishing: Cham, Switzerland, 2016; pp. 295-324. [CrossRef]

245. Doi, S.; Damron, D.S.; Ogawa, K.; Tanaka, S.; Horibe, M.; A Murray, P. K(+) channel inhibition, calcium signaling, and vasomotor tone in canine pulmonary artery smooth muscle. Am. J. Physiol. Lung Cell. Mol. Physiol. 2000, 279, L242-L251. [CrossRef] [PubMed]

246. Joshi, S.; Balan, P.; Gurney, A.M. Pulmonary vasoconstrictor action of KCNQ potassium channel blockers. Respir. Res. 2006, 7, 31. [CrossRef]

247. Wang, J.; Juhaszova, M.; Rubin, L.J.; Yuan, X.J. Hypoxia inhibits gene expression of voltage-gated K+ channel alpha subunits in pulmonary artery smooth muscle cells. J. Clin. Investig. 1997, 100, 2347-2353. [CrossRef]

248. Wang, J.; Weigand, L.; Wang, W.; Sylvester, J.T.; Shimoda, L.A. Chronic hypoxia inhibits Kv channel gene expression in rat distal pulmonary artery. Am. J. Physiol. Lung Cell. Mol. Physiol. 2005, 288, L1049-L1058. [CrossRef] 
249. Mittal, M.; Gu, X.Q.; Pak, O.; Pamenter, M.E.; Haag, D.; Fuchs, D.B.; Schermuly, R.T.; Ghofrani, H.-A.; Brandes, R.P.; Seeger, W.; et al. Hypoxia induces Kv channel current inhibition by increased NADPH oxidase-derived reactive oxygen species. Free Radic. Biol. Med. 2012, 52, 1033-1042. [CrossRef]

250. Platoshyn, O.; Yu, Y.; Golovina, V.A.; McDaniel, S.S.; Krick, S.; Li, L.; Wang, J.-Y.; Rubin, L.J.; Yuan, J.X.-J. Chronic hypoxia decreases KV channel expression and function in pulmonary artery myocytes. Am. J. Physiol. Cell. Mol. Physiol. 2001, 280, L801-L812. [CrossRef]

251. Fan, Z.; Liu, B.; Zhang, S.; Liu, H.; Li, Y.; Wang, N.; Liu, Y.; Li, J.; Wang, N.; Liu, Y.; et al. YM155, a selective survivin inhibitor, reverses chronic hypoxic pulmonary hypertension in rats via upregulating voltage-gated potassium channels. Clin. Exp. Hypertens. 2015, 37, 381-387. [CrossRef]

252. Michelakis, E.D.; McMurtry, M.S.; Wu, X.-C.; Dyck, J.R.B.; Moudgil, R.; Hopkins, T.A.; Lopaschuk, G.D.; Puttagunta, L.; Waite, R.; Archer, S.L. Dichloroacetate, a metabolic modulator, prevents and reverses chronic hypoxic pulmonary hypertension in rats: Role of increased expression and activity of voltage-gated potassium channels. Circulation 2002, 105, 244-250. [CrossRef]

253. Zheng, L.; Liu, M.; Wei, M.; Liu, Y.; Dong, M.; Luo, Y.; Zhao, P.; Dong, H.; Niu, W.; Yan, Z.; et al. Tanshinone IIA attenuates hypoxic pulmonary hypertension via modulating KV currents. Respir. Physiol. Neurobiol. 2015, 205, 120-128. [CrossRef]

254. Frazzini, V.; Guarnieri, S.; Bomba, M.; Navarra, R.; Morabito, C.; A Mariggiò, M.; Sensi, S.L. Altered Kv2.1 functioning promotes increased excitability in hippocampal neurons of an Alzheimer's disease mouse model. Cell Death Dis. 2016, 7, e2100. [CrossRef] [PubMed]

255. Morecroft, I.; Murray, A.; Nilsen, M.; Gurney, A.M.; MacLean, M.R. Treatment with the Kv7 potassium channel activator flupirtine is beneficial in two independent mouse models of pulmonary hypertension. Br. J. Pharmacol. 2009, 157, 1241-1249. [CrossRef] [PubMed]

256. Zuo, X.; Zong, F.; Wang, H.; Wang, Q.; Xie, W.; Wang, H. Iptakalim, a novel ATP-sensitive potassium channel opener, inhibits pulmonary arterial smooth muscle cell proliferation by downregulation of PKC- $\alpha$. J. Biomed. Res. 2011, 25, 392-401. [CrossRef]

257. Revermann, M.; Neofitidou, S.; Kirschning, T.; Schloss, M.; Brandes, R.P.; Hofstetter, C. Inhalation of the BK(Ca)-opener NS1619 attenuates right ventricular pressure and improves oxygenation in the rat monocrotaline model of pulmonary hypertension. PLoS ONE 2014, 9, e86636. [CrossRef] [PubMed]

258. Roth, M.; Rupp, M.; Hofmann, S.; Mittal, M.; Fuchs, B.; Sommer, N.; Parajuli, N.; Quanz, K.; Schubert, D.; Dony, E.; et al. Heme oxygenase-2 and large-conductance Ca2+-activated $\mathrm{K}+$ channels: Lung vascular effects of hypoxia. Am. J. Respir. Crit. Care Med. 2009, 180, 353-364. [CrossRef]

259. Nielsen, G.; Wandall-Frostholm, C.; Sadda, V.; Oliván-Viguera, A.; Lloyd, E.E.; Bryan, R.M.; Simonsen, U.; Köhler, R. Alterations of N-3 polyunsaturated fatty acid-activated K2P channels in hypoxia-induced pulmonary hypertension. Basic Clin. Pharmacol. Toxicol. 2013, 113, 250-258. [CrossRef]

260. Pandit, L.M.; Lloyd, E.E.; Reynolds, J.O.; Lawrence, W.S.; Reynolds, C.; Wehrens, X.H.; Bryan, R.M. TWIK-2 Channel Deficiency Leads to Pulmonary Hypertension Through a Rho-Kinase-Mediated Process. Hypertension 2014, 64, 1260-1265. [CrossRef]

261. Kitagawa, M.G.; Reynolds, J.O.; Durgan, D.; Rodney, G.; Karmouty-Quintana, H.; Bryan, R.; Pandit, L.M. Twik-2(-/-) mouse demonstrates pulmonary vascular heterogeneity in intracellular pathways for vasocontractility. Physiol. Rep. 2019, 7, e13950. [CrossRef]

262. Antigny, F.; Hautefort, A.; Meloche, J.; Belacel-Ouari, M.; Manoury, B.; Rucker-Martin, C.; Péchoux, C.; Potus, F.; Nadeau, V.; Tremblay, E.; et al. Potassium Channel Subfamily K Member 3 (KCNK3) Contributes to the Development of Pulmonary Arterial Hypertension. Circulation 2016, 133, 1371-1385. [CrossRef]

263. Kitagawa, M.G.; Reynolds, J.O.; Wehrens, X.H.; Bryan, R.M., Jr.; Pandit, L.M. Hemodynamic and Pathologic Characterization of the TASK-1(-/-) Mouse Does Not Demonstrate Pulmonary Hypertension. Front. Med. (Lausanne) 2017, 4, 177. [CrossRef]

264. Tang, G.; Wu, L.; Wang, R. The Effect of Hydroxylamine on KATP Channels in Vascular Smooth Muscle and Underlying Mechanisms. Mol. Pharmacol. 2005, 67, 1723-1731. [CrossRef] [PubMed]

265. Hattori, T.; Kajikuri, J.; Katsuya, H.; Itoh, T. Effects of $\mathrm{H} 2 \mathrm{O} 2$ on membrane potential of smooth muscle cells in rabbit mesenteric resistance artery. Eur. J. Pharmacol. 2003, 464, 101-109. [CrossRef]

266. Wei, E.P.; Kontos, H.A.; Beckman, J.S. Mechanisms of cerebral vasodilation by superoxide, hydrogen peroxide, and peroxynitrite. Am. J. Physiol. 1996, 271 Pt 2, H1262-H1266. [CrossRef] 
267. Fukumoto, M.; Nakaizumi, A.; Zhang, T.; Lentz, S.I.; Shibata, M.; Puro, D.G. Vulnerability of the retinal microvasculature to oxidative stress: Ion channel-dependent mechanisms. Am. J. Physiol. Cell Physiol. 2012, 302, C1413-C1420. [CrossRef] [PubMed]

268. Ichinari, K. Direct Activation of the ATP-sensitive Potassium Channel by Oxygen Free Radicals in Guinea-pig Ventricular Cells:its Potentiation by MgADP. J. Mol. Cell. Cardiol. 1996, 28, 1867-1877. [CrossRef]

269. Ohashi, M.; Faraci, F.; Heistad, D. Peroxynitrite hyperpolarizes smooth muscle and relaxes internal carotid artery in rabbit via ATP-sensitive K+ channels. Am. J. Physiol. Heart Circ. Physiol. 2005, 289, H2244-H2250. [CrossRef]

270. Armstead, W.M. Endothelin-Induced Cyclooxygenase-Dependent Superoxide Generation Contributes to K+ Channel Functional Impairment after Brain Injury. J. Neurotrauma 2001, 18, 1039-1048. [CrossRef]

271. Yasui, S.; Mawatari, K.; Morizumi, R.; Furukawa, H.; Shimohata, T.; Harada, N.; Takahashi, A.; Nakaya, Y. Hydrogen peroxide inhibits insulin-induced ATP-sensitive potassium channel activation independent of insulin signaling pathway in cultured vascular smooth muscle cells. J. Med Investig. 2012, 59, 36-44. [CrossRef]

272. Thengchaisri, N.; Kuo, L. Hydrogen peroxide induces endothelium-dependent and -independent coronary arteriolar dilation: Role of cyclooxygenase and potassium channels. Am. J. Physiol. Heart Circ. Physiol. 2003, 285, H2255-H2263. [CrossRef]

273. Zhang, D.X.; Borbouse, L.; Gebremedhin, D.; Mendoza, S.A.; Zinkevich, N.S.; Li, R.; Gutterman, D.D. $\mathrm{H} 2 \mathrm{O} 2$-induced dilation in human coronary arterioles: Role of protein kinase $\mathrm{G}$ dimerization and large-conductance Ca2+-activated K+ channel activation. Circ. Res. 2012, 110, 471-480. [CrossRef]

274. Hayabuchi, Y.; Nakaya, Y.; Matsuoka, S.; Kuroda, Y. Hydrogen peroxide-induced vascular relaxation in porcine coronary arteries is mediated by Ca2+-activated K+ channels. Heart Vessel. 1998, 13, 9-17. [CrossRef] [PubMed]

275. Iida, Y.; Katusic, Z.S.; Wei, E.P. Mechanisms of Cerebral Arterial Relaxations to Hydrogen Peroxide. Stroke 2000, 31, 2224-2230. [CrossRef] [PubMed]

276. Zhao, K.S.; Liu, J.; Yang, G.Y.; Jin, C.; Huang, Q.; Huang, X. Peroxynitrite leads to arteriolar smooth muscle cell membrane hyperpolarization and low vasoreactivity in severe shock. Clin. Hemorheol. Microcirc. 2000, 23, 259-267. [PubMed]

277. Au, A.L.; Seto, S.W.; Chan, S.; Chan, M.; Kwan, Y. Modulation by homocysteine of the iberiotoxin-sensitive, $\mathrm{Ca} 2+$-activated $\mathrm{K}+$ channels of porcine coronary artery smooth muscle cells. Eur. J. Pharmacol. 2006, 546, 109-119. [CrossRef]

278. Brakemeier, S.; Eichler, I.; Knorr, A.; Fassheber, T.; Köhler, R.; Hoyer, J.; Köhler, R. Modulation of $\mathrm{Ca} 2+$-activated $\mathrm{K}+$ channel in renal artery endothelium in situ by nitric oxide and reactive oxygen species. Kidney Int. 2003, 64, 199-207. [CrossRef]

279. Liu, Y.; Terata, K.; Chai, Q.; Li, H.; Kleinman, L.H.; Gutterman, D.D. Peroxynitrite inhibits Ca2+-activated K+ channel activity in smooth muscle of human coronary arterioles. Circ. Res. 2002, 91, 1070-1076. [CrossRef]

280. Frisbee, J.C.; Maier, K.G.; Stepp, D.W. Oxidant stress-induced increase in myogenic activation of skeletal muscle resistance arteries in obese Zucker rats. Am. J. Physiol. Heart Circ. Physiol. 2002, 283, H2160-H2168. [CrossRef]

281. Somlyo, A.P.; Somlyo, A.V. Ca2+ Sensitivity of Smooth Muscle and Nonmuscle Myosin II: Modulated by G Proteins, Kinases, and Myosin Phosphatase. Physiol. Rev. 2003, 83, 1325-1358. [CrossRef]

282. Fagan, K.A.; Oka, M.; Bauer, N.R.; Gebb, S.A.; Ivy, D.D.; Morris, K.G.; McMurtry, I.F. Attenuation of acute hypoxic pulmonary vasoconstriction and hypoxic pulmonary hypertension in mice by inhibition of Rho-kinase. Am. J. Physiol. Lung Cell. Mol. Physiol. 2004, 287, L656-L664. [CrossRef]

283. Kitazawa, T.; Eto, M.; Woodsome, T.P.; Brautigan, D.L. Agonists Trigger G Protein-mediated Activation of the CPI-17 Inhibitor Phosphoprotein of Myosin Light Chain Phosphatase to Enhance Vascular Smooth Muscle Contractility. J. Biol. Chem. 2000, 275, 9897-9900. [CrossRef]

284. Hartmann, S.; Ridley, A.J.; Lutz, S. The Function of Rho-Associated Kinases ROCK1 and ROCK2 in the Pathogenesis of Cardiovascular Disease. Front. Pharmacol. 2015, 6, 276. [CrossRef]

285. Pankey, E.A.; Byun, R.J.; Smith, W.B.; Bhartiya, M.; Bueno, F.R.; Badejo, A.M.; Stasch, J.-P.; Murthy, S.N.; Nossaman, B.; Kadowitz, P.J. The Rho kinase inhibitor azaindole-1 has long-acting vasodilator activity in the pulmonary vascular bed of the intact chest rat. Can. J. Physiol. Pharmacol. 2012, 90, 825-835. [CrossRef] [PubMed] 
286. Abe, K.; Tawara, S.; Oi, K.; Hizume, T.; Uwatoku, T.; Fukumoto, Y.; Kaibuchi, K.; Shimokawa, H. Long-Term Inhibition of Rho-kinase Ameliorates Hypoxia-Induced Pulmonary Hypertension in Mice. J. Cardiovasc. Pharmacol. 2006, 48, 280-285. [CrossRef] [PubMed]

287. Oka, M.; A Fagan, K.; Jones, P.L.; McMurtry, I.F. Therapeutic potential of RhoA/Rho kinase inhibitors in pulmonary hypertension. Br. J. Pharmacol. 2008, 155, 444-454. [CrossRef] [PubMed]

288. Guilluy, C.; Sauzeau, V.; Rolli-Derkinderen, M.; Guerin, P.; Sagan, C.; Pacaud, P.; Loirand, G. Inhibition of RhoA/Rho kinase pathway is involved in the beneficial effect of sildenafil on pulmonary hypertension. Br. J. Pharmacol. 2005, 146, 1010-1018. [CrossRef]

289. Ziino, A.J.; Ivanovska, J.; Belcastro, R.; Kantores, C.; Xu, E.Z.; Lau, M.; McNamara, P.J.; Tanswell, A.K.; Jankov, R.P. Effects of rho-kinase inhibition on pulmonary hypertension, lung growth, and structure in neonatal rats chronically exposed to hypoxia. Pediatr. Res. 2010, 67, 177-182. [CrossRef]

290. Wang, Z.; Lannér, M.C.; Jin, N.; Swartz, D.; Li, L.; Rhoades, R.A. Hypoxia inhibits myosin phosphatase in pulmonary arterial smooth muscle cells: Role of Rho-kinase. Am. J. Respir. Cell Mol. Biol. 2003, 29, 465-471. [CrossRef]

291. Woodsome, T.P.; Polzin, A.; Kitazawa, K.; Eto, M. Agonist- and depolarization-induced signals for myosin light chain phosphorylation and force generation of cultured vascular smooth muscle cells. J. Cell Sci. 2006, 119 Pt 9, 1769-1780. [CrossRef]

292. Mita, M.; Tanaka, H.; Yanagihara, H.; Nakagawà, J.-I.; Hishinuma, S.; Sutherland, C.; Walsh, M.P.; Shoji, M. Membrane depolarization-induced RhoA/Rho-associated kinase activation and sustained contraction of rat caudal arterial smooth muscle involves genistein-sensitive tyrosine phosphorylation. J. Smooth Muscle Res. 2013, 49, 26-45. [CrossRef]

293. Porras-González, C.; Ordoñez, A.; Castellano, A.; Ureña, J. Regulation of RhoA/ROCK and sustained arterial contraction by low cytosolic $\mathrm{Ca} 2+$ levels during prolonged depolarization of arterial smooth muscle. Vasc. Pharmacol. 2017, 93, 33-41. [CrossRef]

294. Sakurada, S.; Takuwa, N.; Sugimoto, N.; Wang, Y.; Seto, M.; Sasaki, Y.; Takuwa, N. Ca2+-dependent activation of Rho and Rho kinase in membrane depolarization-induced and receptor stimulation-induced vascular smooth muscle contraction. Circ. Res. 2003, 93, 548-556. [CrossRef] [PubMed]

295. Fukata, Y.; Kaibuchi, K.; Amano, M. Rho-Rho-kinase pathway in smooth muscle contraction and cytoskeletal reorganization of non-muscle cells. Trends Pharmacol. Sci. 2001, 22, 32-39. [CrossRef]

296. Turcotte, S.; Desrosiers, R.R.; Béliveau, R. HIF-1alpha mRNA and protein upregulation involves Rho GTPase expression during hypoxia in renal cell carcinoma. J. Cell Sci. 2003, 116 Pt 11, 2247-2260. [CrossRef]

297. Wennerberg, K.; Der, C.J. Rho-family GTPases: It's not only Rac and Rho (and I like it). J. Cell Sci. 2004, 117 Pt 8, 1301-1312. [CrossRef]

298. Heo, J.; Campbell, S.L. Mechanism of Redox-mediated Guanine Nucleotide Exchange on Redox-active Rho GTPases. J. Biol. Chem. 2005, 280, 31003-31010. [CrossRef] [PubMed]

299. Aghajanian, A.; Wittchen, E.S.; Campbell, S.L.; Burridge, K. Direct Activation of RhoA by Reactive Oxygen Species Requires a Redox-Sensitive Motif. PLoS ONE 2009, 4, e8045. [CrossRef]

300. Chaumais, M.-C.; Ranchoux, B.; Montani, D.; Dorfmüller, P.; Tu, L.; Lecerf, F.; Raymond, N.; Guignabert, C.; Price, L.; Simonneau, G.; et al. N-acetylcysteine improves established monocrotaline-induced pulmonary hypertension in rats. Respir. Res. 2014, 15, 65. [CrossRef]

301. He, B.; Zhang, Y.; Kang, B.; Xiao, J.; Xie, B.; Wang, Z. Protection of oral hydrogen water as an antioxidant on pulmonary hypertension. Mol. Biol. Rep. 2013, 40, 5513-5521. [CrossRef]

302. Jefferson, J.A.; Simoni, J.M.; Escudero, E.; Hurtado, M.-E.; Swenson, E.R.; E Wesson, D.; Schreiner, G.F.; Schoene, R.B.; Johnson, R.J.; Hurtado, A. Increased Oxidative Stress Following Acute and Chronic High Altitude Exposure. High Alt. Med. Biol. 2004, 5, 61-69. [CrossRef] [PubMed]

303. Cracowski, J.-L.; Cracowski, C.; Bessard, G.; Pépin, J.-L.; Bessard, J.; Schwebel, C.; Stanke-Labesque, F.; Pison, C. Increased Lipid Peroxidation in Patients with Pulmonary Hypertension. Am. J. Respir. Crit. Care Med. 2001, 164, 1038-1042. [CrossRef] [PubMed]

304. Smukowska-Gorynia, A.D.; Rzymski, P.; Marcinkowska, J.; Poniedziałek, B.; Komosa, A.; Cieslewicz, A.; Slawek-Szmyt, S.; Janus, M.; Araszkiewicz, A.; Jankiewicz, S.; et al. Prognostic Value of Oxidative Stress Markers in Patients with Pulmonary Arterial or Chronic Thromboembolic Pulmonary Hypertension. Oxid. Med. Cell. Longev. 2019, 2019, 3795320. [CrossRef] [PubMed] 
305. Robbins, I.M.; Morrow, J.D.; Christman, B.W. Oxidant stress but not thromboxane decreases with epoprostenol therapy. Free Radic. Biol. Med. 2005, 38, 568-574. [CrossRef]

306. Hemnes, A.R.; Rathinasabapathy, A.; Austin, E.A.; Brittain, E.L.; Carrier, E.J.; Chen, X.; Fessel, J.P.; Fike, C.D.; Fong, P.; Fortune, N.; et al. A potential therapeutic role for angiotensin-converting enzyme 2 in human pulmonary arterial hypertension. Eur. Respir. J. 2018, 51, 1702638. [CrossRef]

307. Westerhof, B.E.; Saouti, N.; Van Der Laarse, W.J.; Westerhof, N.; Noordegraaf, A.V. Treatment strategies for the right heart in pulmonary hypertension. Cardiovasc. Res. 2017, 113, 1465-1473. [CrossRef] [PubMed]

308. Sharp, J.; Farha, S.; Park, M.M.; Comhair, S.A.; Lundgrin, E.L.; Tang, W.W.; Bongard, R.D.; Merker, M.P.; Erzurum, S.C. Coenzyme Q supplementation in pulmonary arterial hypertension. Redox Biol. 2014, 2, 884-891. [CrossRef] [PubMed]

Publisher's Note: MDPI stays neutral with regard to jurisdictional claims in published maps and institutional affiliations.

(C) 2020 by the authors. Licensee MDPI, Basel, Switzerland. This article is an open access article distributed under the terms and conditions of the Creative Commons Attribution (CC BY) license (http://creativecommons.org/licenses/by/4.0/). 